\title{
A Narrative Review of the Role of Diet and Lifestyle Factors in the Development and Prevention of Endometrial Cancer
}

\author{
Hajar Ku Yasin ${ }^{1}$, Anthony H. Taylor ${ }^{2}$ and Thangesweran Ayakannu ${ }^{3, *}$ \\ 1 Department of Obstetrics \& Gynaecology, Cumberland Infirmary, Carlisle CA2 7HY, UK; \\ hajar.kuyasin@nhs.net \\ 2 Department of Molecular and Cell Biology, University of Leicester, Leicester LE1 7RH, UK; \\ aht13@leicester.ac.uk \\ 3 Gynaecology Oncology Cancer Centre, Liverpool Women's NHS Foundation Trust, Liverpool Women's \\ Hospital, Liverpool L8 7SS, UK \\ * Correspondence: thangesweran.ayakannu@lwh.nhs.uk; Tel.: +44-(0)-151-708-9988 (ext. 4531)
}

Citation: Yasin, H.K.; Taylor, A.H.; Ayakannu, T. A Narrative Review of the Role of Diet and Lifestyle Factors in the Development and Prevention of Endometrial Cancer. Cancers 2021, 13, 2149. https://doi.org/10.3390/ cancers13092149

Academic Editor: Clemens B. Tempfer

Received: 30 December 2020

Accepted: 16 April 2021

Published: 29 April 2021

Publisher's Note: MDPI stays neutral with regard to jurisdictional claims in published maps and institutional affiliations.

Copyright: (c) 2021 by the authors. Licensee MDPI, Basel, Switzerland. This article is an open access article distributed under the terms and conditions of the Creative Commons Attribution (CC BY) license (https:/ / creativecommons.org/licenses/by/ $4.0 /)$.
Simple Summary: The incidence and prevalence of endometrial cancer is increasing globally. The main factors involved in this increase have been the way women live today and what they eat and drink. In fact, the obesity pandemic that is sweeping across the planet is considered to be the main contributory feature. This review aims to introduce to a new audience, those that are not experts in the field, what is known about the different types of endometrial cancer and the mechanisms for their induction and protection. We also seek to summarise the existing knowledge on dietary and lifestyle factors that prevent endometrial development in susceptible populations and identify the main problem in this arena; the paucity of research studies and clinical trials that investigate the interaction(s) between diet, lifestyle and endometrial cancer risk whilst highlighting those areas of promise that should be further investigated.

Abstract: Endometrial cancer is the most common cancer affecting the reproductive organs of women living in higher-income countries. Apart from hormonal influences and genetic predisposition, obesity and metabolic syndrome are increasingly recognised as major factors in endometrial cancer risk, due to changes in lifestyle and diet, whereby high glycaemic index and lipid deposition are prevalent. This is especially true in countries where micronutrients, such as vitamins and minerals are exchanged for high calorific diets and a sedentary lifestyle. In this review, we will survey the currently known lifestyle factors, dietary requirements and hormonal changes that increase an individual's risk for endometrial cancer and discuss their relevance for clinical management. We also examine the evidence that everyday factors and clinical interventions have on reducing that risk, such that informed healthy choices can be made. In this narrative review, we thus summarise the dietary and lifestyle factors that promote and prevent the incidence of endometrial cancer.

Keywords: endometrial cancer; diet; nutrients; hormones; diabetes; lipids; melatonin; obesity; vitamins; minerals

\section{Introduction}

What people eat (dietary patterns) and how they live (lifestyle habits) are the main modifiable risk factors associated with the development of cancer [1]. Keeping a healthy body weight, eating the right foods and undertaking regular exercise are considered important for not only cardiovascular health, but also for cancer prevention. This conclusion has come from many research studies, reviews and government information sources over the past 20 years or so, and have provided a consensus that cessation of smoking, reduced alcohol intake and having a healthy lifestyle are predominantly important in reducing cancer risk [2-4]. Some reports have indicated that psychological stress may be a contributory factor in the development of cancer [5], but such data is scarce and inconclusive. Such 
stressors may impact on lifestyle and diet, which in turn may impact on cancer development [6]. Currently there is no convincing data to suggest stress is an independent factor in the development of EC [7]. Nevertheless, there are many other factors that increase the risk of developing EC. In particular, data has emerged that the storage of fats and lipids may exacerbate any genetic predisposition towards the development of cancer [8,9]. Despite this knowledge, it has been estimated that at least $20 \%$ of all women worldwide will die from cancer alone by 2050, primarily due to the increasing incidence of obesity, which is now in pandemic proportions [10].

For cancers in women, this is of particular importance because oestrogen generated from the fats and lipids stored in adipose tissue or produced by the adrenal cortex are known to be associated with breast, ovarian and endometrial cancer (EC) [11-14]. Many studies have suggested that healthy dietary patterns and good lifestyle habits may also decrease the risk of developing other cancers prevalent in women, such as colorectal, pancreatic and thyroid [15-20]. Of all the female-associated cancers, those of the breast, cervix, ovary and endometrium are foremost in women's minds, because they often know of close family members or friends that have been diagnosed (or have died) with these female-specific cancers. Despite improved overall survival rates for breast, ovarian and endometrial cancers over the past 20 years [21,22], the incidence of EC has increased by $40 \%$ and the mortality rate for women with EC has risen by $20 \%$ in the last decade [23]. This increase in the incidence of EC has been suggested to be caused by two key factors; (1) an increase in obesity in women and (2) an ageing female population. Although these are prominent risk factors, EC is a multifactorial disease, with exposure to excess oestrogen and/or a relative lack of progesterone [24-26] being the biggest stimulator. This is because oestrogen stimulates rapid growth of endometrial cells, whereas progesterone opposes this action. Long-term treatment of menopausal symptoms with conventional hormone replacement therapy consisting of unopposed oestrogen (oestrogen without a protective progestogen) leads to an increased risk of developing EC [24,27-29]. Additionally, other risk factors that have been associated with EC include diabetes, and diets high in sugar, animal fats, and cholesterol (Figure 1) [30-35].

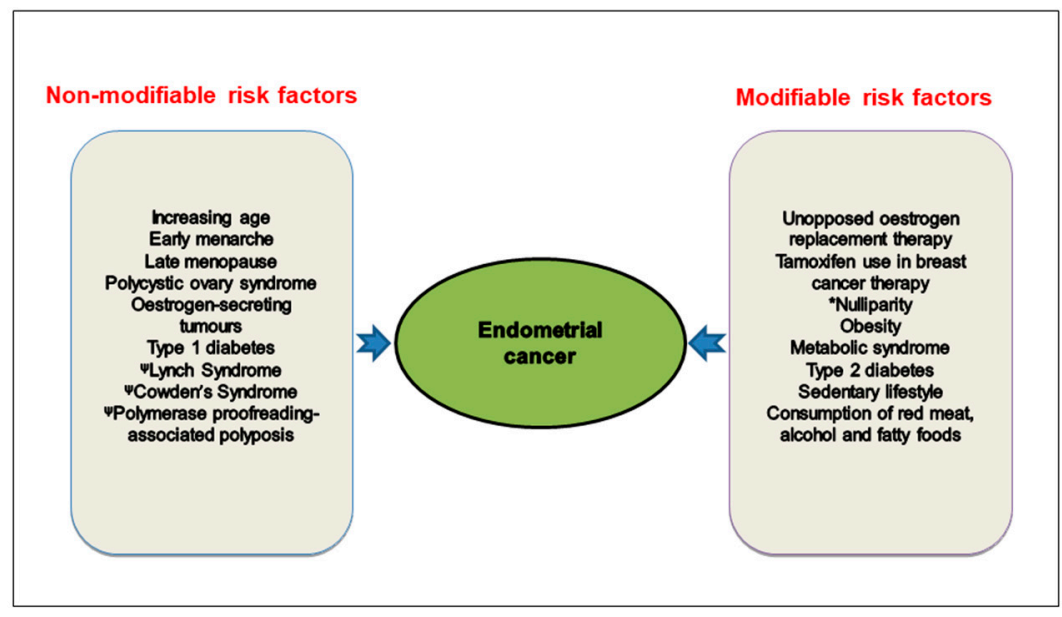

Figure 1. Epidemiological, genetic, clinical, lifestyle and dietary risk factors for the development of endometrial cancers. Two distinct pathways are depicted in which non-modifiable and modifiable risk factors are listed. ${ }^{*}$ Nulliparity is included as modifiable risk factor because pregnancy can reduce the risk of EC development. It could also conceivably be included as a non-modifiable risk factor, since some women are unable to conceive. $\psi$ Familial genetic mutations are also risk factors for EC and are associated with Lynch syndrome, Cowden's syndrome, and Polymerase proof-reading polyposis (see Figure 5). 
This review will focus on the underlying mechanism(s) for the development of EC in relation to these factors, dietary patterns and lifestyle habits [36-39], with numerous studies explored to provide evidence of an association between individual nutrients or foods and EC risk. What is important to a patient worried about developing cancer, is not only what lifestyle and dietary choices should be avoided, but also what should be encompassed and so lessen the risk of developing the disease in the first place, or what foods and lifestyle adaptations should be adopted once the disease has been diagnosed. It is our contention that an examination of existing dietary patterns and their association with EC risk could provide a wider and more realistic estimation of possible relationships between food and healthy habits in a particular female population. This knowledge may provide useful areas for future research into an increasingly prevalent public health issue for our ageing female population.

\section{Methods}

A literature search of the Embase, Medline, ClinicalKey, CINAHL and PubMed databases was conducted (from 1974 to May 2020) with the following search terms (*"endometrium cancer" /OR *"endometrium carcinoma" /OR *"endometrium sarcoma" /OR (endometri* ADJ2 cancer*/OR ("endometrial neoplasms" /OR (*"carcinoma, endometrioid).ti,ab) AND (*“Diet"/OR ("lifestyle*").ti,ab)) [Publication types Article OR Conference Paper OR Journal OR Review] [English language] [Female] [Human age groups Adult 18 to 64 years OR Aged 65+ years] [Humans]' and yielded 523 PubMed/Embase results and 579 Medline results. Duplicate or irrelevant references were omitted revealing 154 directly applicable citations. The Cochrane systematic reviews database was also searched using the search terms "heathy lifestyle index" and "endometrial cancers" and generated three articles (one from 2015 and two from 2018). The reference lists of these were also scanned, aided by citations provided by the article reviewers and additional references obtained. Only literature supportive of the statements used are provided.

\section{Endometrial Cancer Incidence and Prevalence}

$\mathrm{EC}$ is the 4th most common cancer affecting women in the United Kingdom, accounting for $5 \%$ of all new cases annually. It is the 8 th most common cause of death in women in the UK, with $34 \%$ of the EC cases considered to be preventable [23]. It is mainly a disease of high-income countries, with the highest incidences occurring in Central and Eastern Europe, North America and Northern Europe (Table 1).

Table 1. The effect of income levels on the worldwide incidence, prevalence and mortality values for endometrial cancer in 2018 .

\begin{tabular}{cccccccccc}
\hline & \multicolumn{3}{c}{ Incidence } & \multicolumn{2}{c}{ Prevalence } & \multicolumn{3}{c}{ Mortality } \\
\cline { 2 - 10 } Population & Number & $\begin{array}{c}\text { Crude } \\
\text { Rate }\end{array}$ & $\begin{array}{c}\text { Standardised } \\
\text { Rate }\end{array}$ & 5-Year & $\begin{array}{c}* * \text { Propor- } \\
\text { tions }\end{array}$ & $\begin{array}{c}\text { Number } \\
\text { ** Crude } \\
\text { Rate }\end{array}$ & $\begin{array}{c}\text { Standardised } \\
\text { Rate }\end{array}$ \\
\hline High Income & 173,957 & 28.5 & 15.5 & 670,689 & 109.8 & 36,911 & 6.0 & 2.4 \\
\hline Upper Middle Income & 146,537 & 11.3 & 8.2 & 451,728 & 34.7 & 31,725 & 2.4 & 1.6 \\
\hline Lower Middle Income & 52,535 & 3.6 & 3.9 & 140,955 & 9.5 & 17,632 & 1.2 & 1.3 \\
\hline Low Income & 7,169 & 1.9 & 3.2 & 13,968 & 3.7 & 3,331 & 0.88 \\
\hline
\end{tabular}

Although EC incidence has historically been much lower in Asia, Africa and South America (Figure 2) [40-42], the economic boom in these continents over the past decade has allowed a dietary change towards a more Westernised diet, even when age is taken into account $[40,41]$. This is an issue that can be directly attributable to a change in diet/lifestyle and in some cases to an increased production of circulating oestrogens [43-45] or the use of 
unopposed oestrogen therapy for menopausal symptoms, where the risk of EC increases by up to 70-fold; adding a progestogen reduces the risk to that of the general population [46].

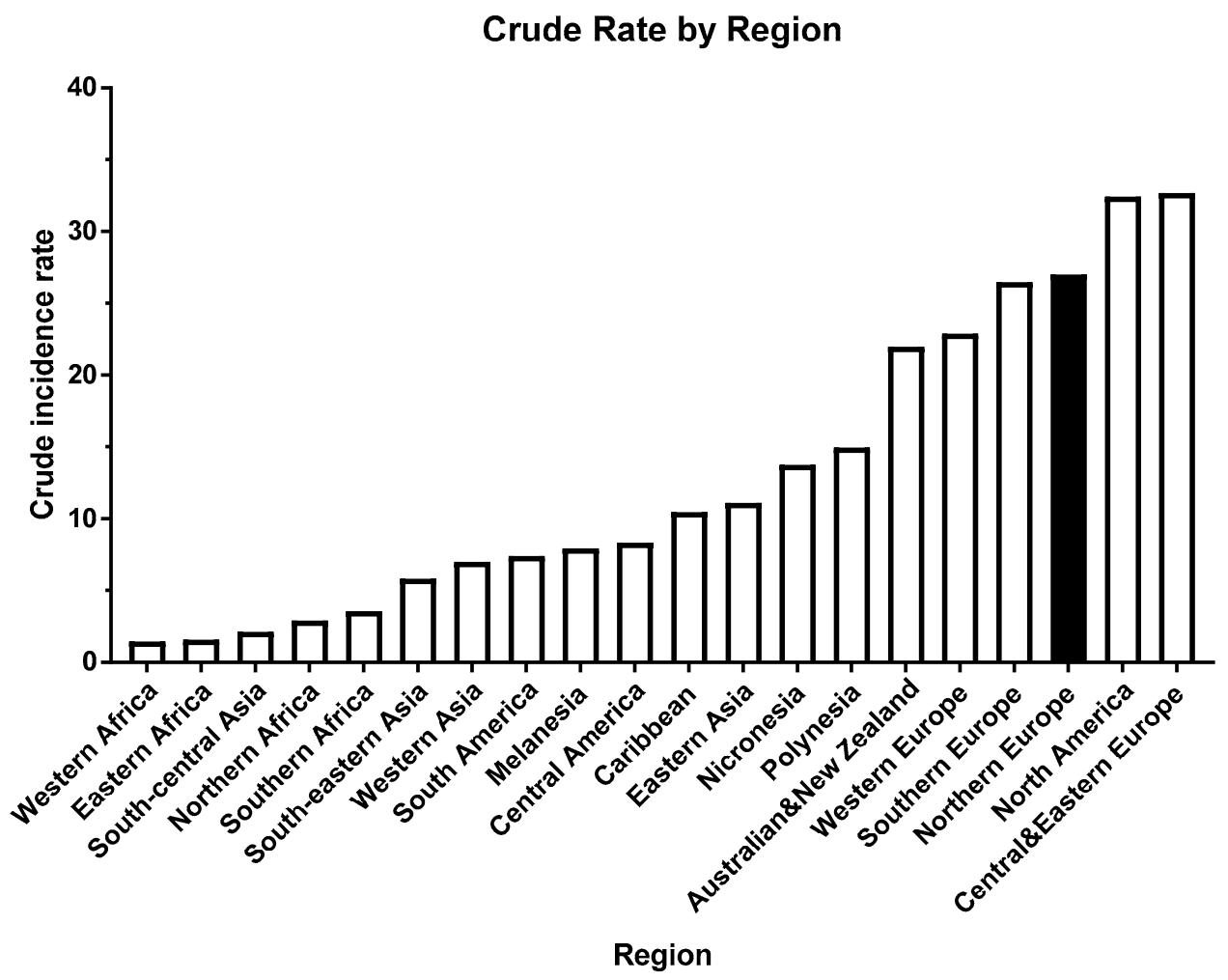

Figure 2. Estimated crude incidence rate for endometrial cancer (all ages; 0-85+) in 2018, based on different regions of the world. Data are shown from lowest incidence rate to highest incidence rates with Northern Europe highlighted with the solid bar. Adapted from [40].

It is also important to note that income is also related to EC incidence prevalence and hence mortality rates (Table 1), with women from more affluent backgrounds having higher values of these endpoints than women from less affluent backgrounds. This again is attributed to easier access to high calorific foods and increased risk of obesity [47,48]. Fat stored in adipose tissues can generate oestrogen precursors that drive endometrial hyperplasia and carcinoma [32,34,35,49-53]. Some studies have shown that as many as $40 \%$ of EC cases may be attributable to this [54]. Weighing more than $200 \mathrm{lbs}$ ( $\sim 90 \mathrm{~kg}$ or $\sim 14$ stones) increases risk by about 7-fold [46]. In a 2007 analysis of data on 1.2 million women, each 10-unit increment in body mass index (BMI) was associated with a nearly 3-fold increase in EC risk [55]. Other mechanisms by which obesity may increase EC risk include perturbation of glucose regulation and promotion of an inflammatory state throughout the body [25,56]. A recent study of 33,436 postmenopausal EC cases confirmed that BMI was a strong predictor of EC risk (RR 4.41; 95\% CI 2.7-7.2 for BMI $\geq 35 \mathrm{~kg} / \mathrm{m}^{2}$ ), but this association was no longer evident among users who had previously used HRT [57]. These data need to be examined in detail, since menopausal status and histological subtypes had no bearing on the relative risk calculations [58]. This means that it did not matter if a woman was postmenopausal or what histologically defined type of EC she was diagnosed with, her risk of developing EC was strongly positively correlated with her BMI at the time of diagnosis, with the relative risk for each study being 20.7 when BMI was $\geq 42 \mathrm{~kg} / \mathrm{m}^{2}$ or 4.41 when BMI was $\geq 35 \mathrm{~kg} / \mathrm{m}^{2}$, respectively [58] and that previous exposure to the hormones in HRT either completely or partially negated this effect. These data suggest that residual drug deposition has an on-going interaction with the control of BMI and subsequent reduction in EC risk. Support for these observations comes from an older 
cohort study of 103,882 postmenopausal women where different forms of HRT significantly modified the relationship between BMI and EC risk [59].

\section{Types of Endometrial Cancer}

EC can be categorised based on cellular morphology and where the malignant cells are situated within the uterus or outside this organ (metastatic disease/secondary tumour/recurrent disease). The major division of EC types is based on tissue morphology of which endometrioid adenocarcinoma, clear cell carcinoma, mixed cell carcinoma, mucinous carcinoma, serous carcinoma, squamous carcinoma, undifferentiated carcinoma and metastatic carcinoma are the major types (Table 2). Endometrioid adenocarcinoma, also described as type 1, is the most common type of EC and accounts for $80-90 \%$ of cases [60]. Phenotypically, endometrioid adenocarcinoma is considered to be oestrogen-dependent, in that tumour cell survival is dependent on endogenous or exogenous oestrogen stimulation $[54,61]$. It is therefore not surprising that exogenous or endogenous oestrogen stimulation results in a higher incidence of type $1 \mathrm{EC}$. Non-endometrioid, also described as type $2 \mathrm{EC}$ consists of the other subtypes of EC in the list above, excluding endometrioid adenocarcinoma, with serous carcinoma $(\sim 10 \%)$ and clear cell carcinoma $(\sim 3 \%)$ being the most prevalent [62]. The other type $2 \mathrm{EC}$ types (metastatic, mixed cell, undifferentiated, squamous and mucinous types are rarer forms and make up the remaining percentages) [63]. The major difference between type 1 and type $2 \mathrm{EC}$ is that type 2 (non-endometrioid) forms of malignancy do not require oestrogen stimulation for cell survival due to gene mutations [64]. Furthermore, when considering both biological and clinical parameters, gene mutations are currently used for EC classification, whereby type 1 carcinomas that comprise $80-90 \%$ of newly-diagnosed EC, have alterations in the phosphatase and tensin homolog gene (PTEN), the Kirsten ras gene (KRAS), the beta-catenin gene (CTNNB1) and DNA characterised by microsatellite instability (MSI) $[65,66]$. These tumours are associated with better prognosis $[65,66]$. Whereas, in type 2 EC tumours are defined in this classification system as having TP53 mutations, a high Ki-67 (MIB1) score (a marker of proliferation), tumour suppressor gene p16 inactivation, increased cadherin-1 gene (CDH1) expression and the amplification of human epidermal growth factor receptor 2 gene (HER2), which is associated with metastatic disease and tumour spread $[67,68]$.

In addition, in order to provide a more accurate classification for prognostic purposes, clinicopathological information and gene mutation data have been integrated into a more modern classification system [69]. This newer system performed by The Cancer Genome Atlas (TCGA) consortium provides four prognostic subgroups, with the POLE group having the best prognosis (Figure 3A) [62,63,70,71]. The tumours here have POLE exonuclease domain mutations, which is part of the catalytic unit of DNA polymerase. The microsatellite instability (MSI) group, composed of patients with EC lesions having DNA microsatellite instability have the next worst prognosis, followed by the Copy Number Low (CNL) and Copy Number High (CNH) groups (Figure 3B). Copy number groups are defined by a differential profile of copy alterations (CNA), with the $\mathrm{CNH}$ group particularly presenting an elevated incidence of tumour suppressor p53 (TP53) mutations and worse prognosis when compared to the low copy number group [70]. Linking these four molecular tumour subgroups to existing FIGO classifications is problematic, and not straight-forward since there is some overlap in these molecular markers for type 1 and type $2 \mathrm{EC}[62,71]$, but in general TP53 mutations are more frequently associated with type 2 EC [serous carcinoma (59-93\%), carcinosarcoma (44-91\%) and clear cell carcinoma (28-46\%)] than with type 1 EC (5-14\%) (Figure 3B) [71]. By contrast, PTEN mutations are associated more with type 1 EC $(64-80 \%)$, than with type 2 EC (serous carcinoma (2-3\%), carcinosarcoma (11-33\%) and clear cell carcinoma $(0-21 \%)$ ). Details on other TCGA gene mutations (and others not mentioned herein can be found in a recent review on this subject and references therein [71]) and their relative frequencies are shown in Table 3 . The effect of tumour grading in type $1 \mathrm{EC}$ can also be of use in designing treatment strategies [71] but has also come under scrutiny and remains controversial when molecular profiling is applied because tumour classification 
itself is complicated when stage and grade are applied [72,73]. Obviously, more work on how to best classify endometrial cancer types and subtypes for risk prevention, diagnosis, prognosis and treatment is required, but beyond the scope of the current review.

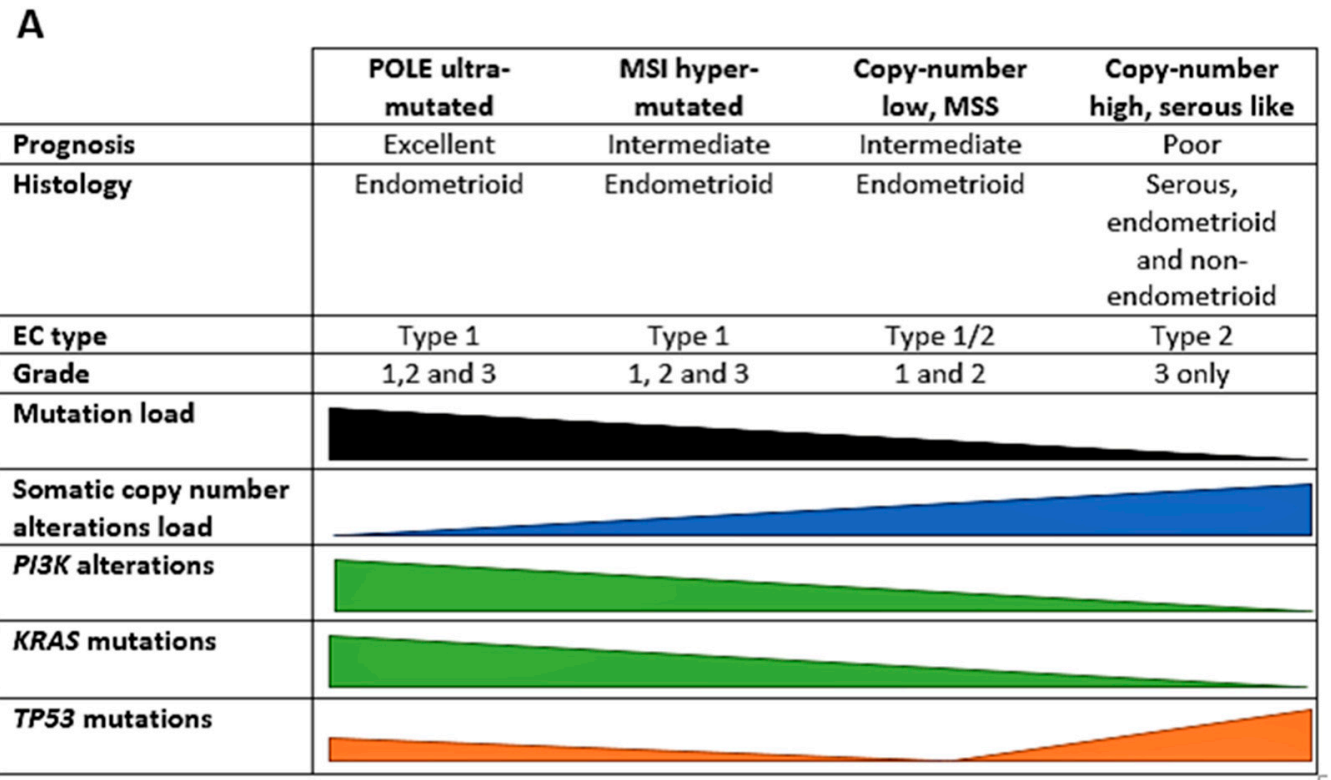

\section{B}

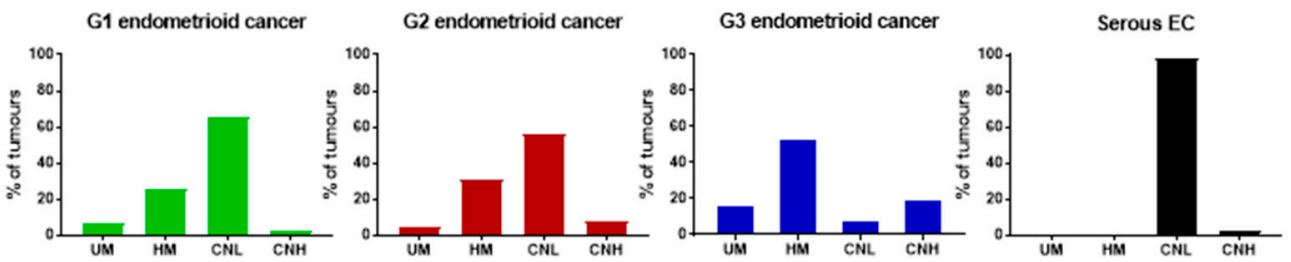

Figure 3. Overview of the molecular classification systems for EC. Panel (A) indicates that genetic mutations are related to the four genomic classes of EC, defined as the Cancer Genome Atlas (TCGA) classification through POLE mutations, which are ultramutated (UM); Multisatellite (MSI) instability events, which are hypermutated events (HM); or are copy number low (CNL) or copy number high $(\mathrm{CNH})$. The relationships between these four genomic classes and patient prognosis, pathognomic factors and other gene alterations is depicted. In Panel (B), the distributions of these TCGA genomic classes is shown as a percentage of the tumours based on the trialistic grading system and with respect the Type 2 serous EC. The \% of tumours that have ultramutated POLE mutations (UM); hypermutated MSI (HM); or are copy number low (CNL) or copy number high (CNH) are shown. Where the bar is not visible, the data indicate that none of those tumours have that event associated with them. Data are adapted from [70,71]. 
Table 2. Pathological, morphological, endocrine and common molecular genetic changes used to provide a dualistic clinical classification of endometrial cancers (Bokhman Classification).

\begin{tabular}{|c|c|c|c|}
\hline Factor & Type 1 EC & Type 2 EC & References \\
\hline Frequency distribution & $80-90 \%$ & $10-20 \%$ & \multirow{12}{*}[71,74]{} \\
\hline Prognosis & Favourable & Unfavourable & \\
\hline Outcome (5-year survival) & $86 \%$ & $59 \%$ & \\
\hline Onset of menopause & $\geq 50$ years of age & $\leq 50$ years of age & \\
\hline Obesity, hyperlipidaemia and diabetes mellitus association & Yes & No & \\
\hline Association with oestrogen stimulation & Yes & No & \\
\hline Sensitivity to progestagens & High & Low & \\
\hline Background endometrium histology & Hyperplasia & Atrophy & \\
\hline Tumour grade & Low (grade 1-2) & High (grade 3) & \\
\hline Myometrial invasion & Superficial & Deep & \\
\hline Potential for metastatic spread through lymphatic system & Low & High & \\
\hline Reproductive status & Decreased & No disturbance & \\
\hline \multicolumn{4}{|c|}{ Clinicopathologic and molecular alterations } \\
\hline Prototypical histological type & Endometrioid & $\begin{array}{l}\text { Non-endometrioid (serous, clear } \\
\text { cell carcinoma) }\end{array}$ & \multirow{3}{*}[71,75-78]{} \\
\hline Stage at diagnosis & Early (FIGO stage I-II) & Advanced (FIGO stage III-IV) & \\
\hline ER and PR receptor expression & High & Low & \\
\hline \multicolumn{4}{|c|}{ Common genetic alterations } \\
\hline Microsatellite instability * & $28-40 \%$ & $0-2 \%$ & \multirow{12}{*}[66,70,71,79-83]{} \\
\hline PTEN mutation & $52-78 \%$ & $1-11 \%$ & \\
\hline TP53 mutation & $9-12 \%$ & $60-91 \%$ & \\
\hline POLE mutation & $11-20 \%$ & $0-7 \%$ & \\
\hline KRAS mutation & $15-43 \%$ & $2-8 \%$ & \\
\hline PIK3CA mutation & $36-52 \%$ & $24-42 \%$ & \\
\hline PIK3R1 mutation & $21-43 \%$ & $0-12 \%$ & \\
\hline ARID1A mutation & $25-48 \%$ & $6-11 \%$ & \\
\hline CTNNB1 mutation & $23-24 \%$ & $0-3 \%$ & \\
\hline PPP2R1A mutation & $5-7 \%$ & $15-43 \%$ & \\
\hline ERRB2 mutation & $1-4 \%$ & $26-44 \%$ & \\
\hline HER2 amplification & 0 & $27-44 \%$ & \\
\hline
\end{tabular}

* Microsatellite instability is characterised by a deficiency in DNA repair mechanisms.

Table 3. Major driver genes used in the classification of endometrial carcinomas and their somatic frequencies.

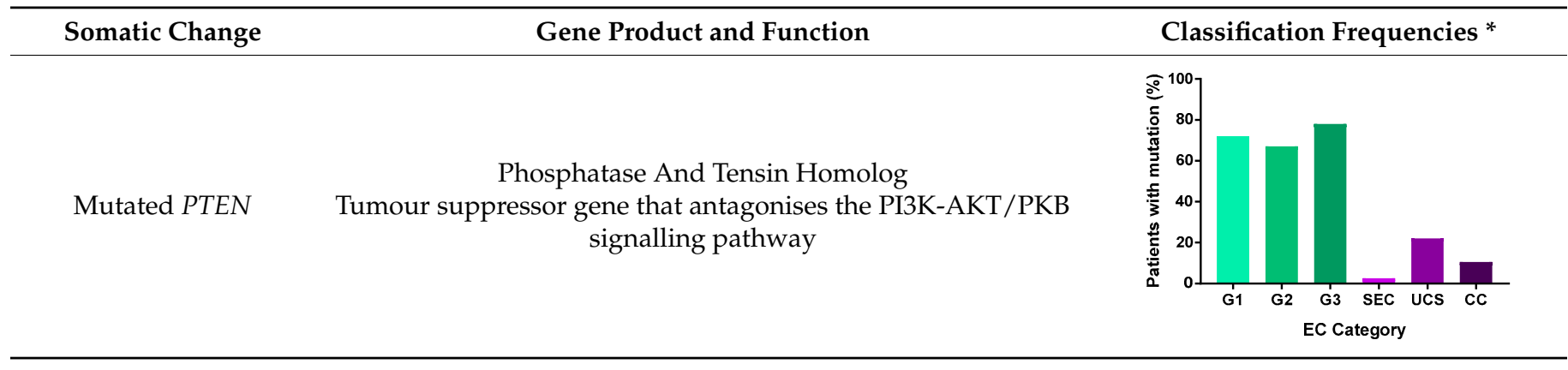


Table 3. Cont.

\begin{tabular}{|c|c|c|}
\hline Somatic Change & Gene Product and Function & Classification Frequencies * \\
\hline Mutated ARID1A & $\begin{array}{c}\text { AT-Rich Interactive Domain-Containing Protein 1A } \\
\text { A component of SWI/SNF chromatin remodelling complexes } \\
\text { that represses expression of select genes through changing } \\
\text { chromatin structure }\end{array}$ & 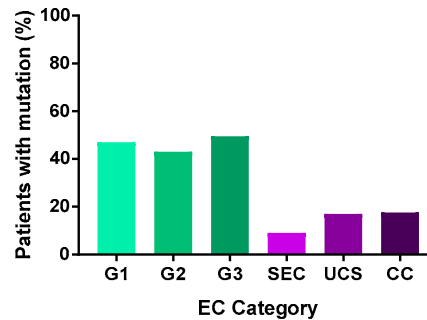 \\
\hline
\end{tabular}

Phosphatidylinositol-4,5-Bisphosphate 3-Kinase Catalytic Subunit Alpha

Mutated PIK3CA Participates in cellular signalling in response to various growth factors and is involved in the activation of AKT1-PDPK1 signalling cascades involved in cell growth and survival.

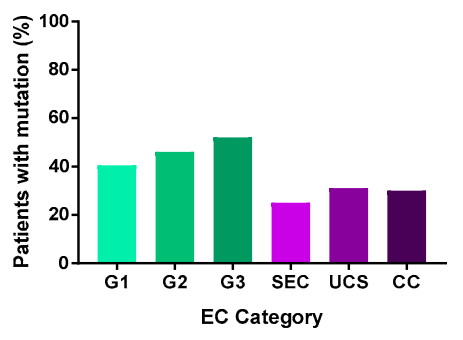

Phosphoinositide-3-Kinase Regulatory Subunit 1

Acts as an adapter, mediating the association of the p110

Mutated PIK3R1 catalytic unit to the plasma membrane, which is necessary for the insulin-stimulated increase in glucose uptake and glycogen synthesis in insulin-sensitive tissues.

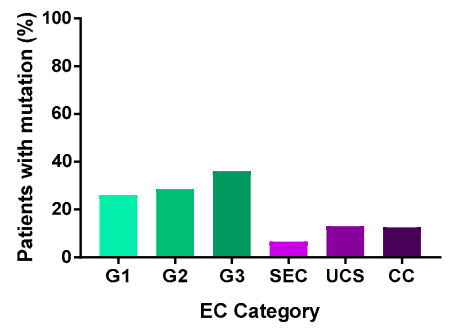

KRAS Proto-Oncogene, GTPase

Mutated KRAS

Plays an important role in the regulation of cell proliferation by promoting oncogenic events by inducing transcriptional silencing of tumour suppressor genes.

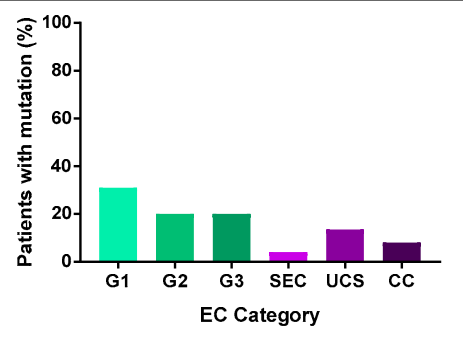

Catenin Beta 1

Mutated CTNNB1

A key component in the Wnt signalling pathway and in insulin internalisation. When mutated, it accumulates in the nucleus, where it acts as a coactivator for transcription factors of the TCF/LEF family, leading to activation of Wnt responsive genes.

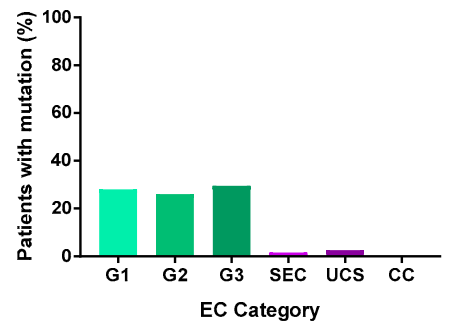

This genetic aberration is associated with dysfunctional DNA mismatch repair mechanisms. The major protein product MLH1

Microsatellite Instability (MSI) interacts with PMS2 to introduce single-strand breaks near the

DNA mismatch and thus generates new entry points for the exonuclease EXO1 to degrade the strand containing the mismatch.

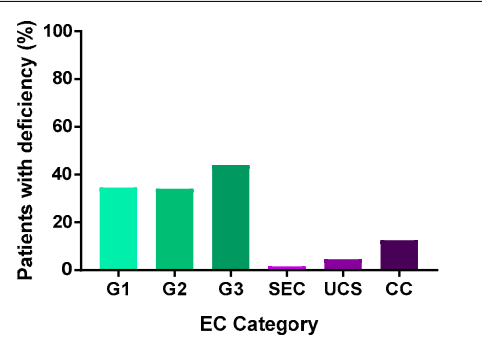


Table 3. Cont.

\begin{tabular}{|c|c|c|}
\hline Somatic Change & Gene Product and Function & Classification Frequencies * \\
\hline Mutated FGFR2 & $\begin{array}{c}\text { Fibroblast Growth Factor Receptor } 2 \\
\text { Plays an essential role in the regulation of cell proliferation, } \\
\text { differentiation, migration and apoptosis and mediates } \\
\text { activation of RAS, MAPK1/ERK2, MAPK3/ERK1 and the MAP } \\
\text { kinase signalling pathway, as well as the AKT1 signalling } \\
\text { pathway. }\end{array}$ & 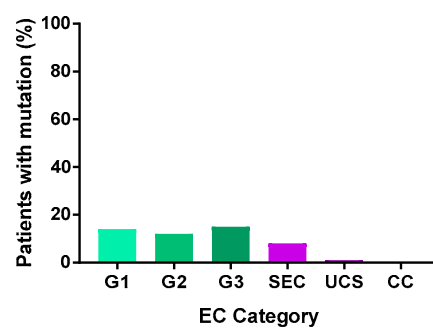 \\
\hline Mutated POLE & $\begin{array}{l}\text { DNA Polymerase Epsilon, Catalytic Subunit } \\
\text { Catalytic component of the DNA polymerase epsilon complex } \\
\text { and participates in chromosomal DNA replication. It has } 3^{\prime}-5^{\prime} \\
\text { proofreading exonuclease activity that corrects errors arising } \\
\text { during DNA replication and so aids DNA synthesis during } \\
\text { DNA repair. }\end{array}$ & 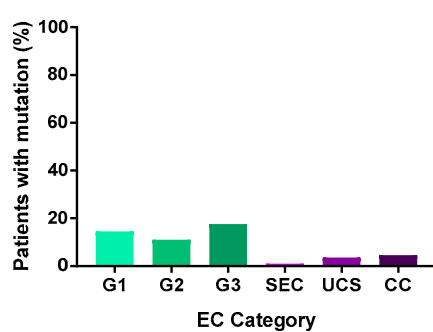 \\
\hline
\end{tabular}

Tumor Protein P53

Acts as a tumour suppressor in many tumour types; induces growth arrest or apoptosis depending on the physiological circumstances and cell type. Apoptosis induction is mediated either by stimulation of BAX and FAS antigen expression, or by repression of Bcl-2 expression.
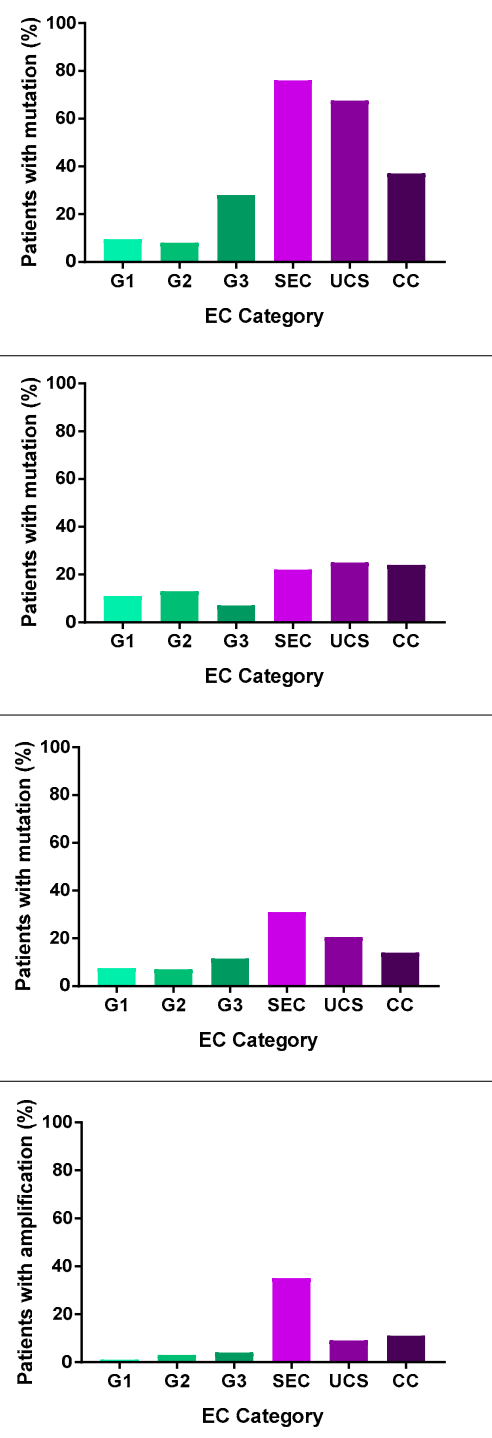

* Type $1 \mathrm{EC}$ are shown in green bars and Type $2 \mathrm{EC}$ are shown in purple bars. $\mathrm{G}=$ grade of tumour; $\mathrm{SEC}=$ serous EC; UCS = uterine carcinosarcoma; $\mathrm{CC}=$ clear cell carcinoma. 


\section{Mechanisms of Oestrogen-Induced Endometrial Cancer}

Firstly, it is known that long-lasting and widespread use of unopposed exogenous oestrogen therapy by postmenopausal women for the treatment of perimenopausal and postmenopausal symptoms (such as vasomotor signs, mood swings, etc.) increases the risk of developing endometrial pathologies, such as epithelial cell hyperplasia, cystic gland formation, polyp formation, adenomyosis, leiomyomata and in some cases these pathologies converge into type $1 \mathrm{EC}$ in susceptible women [84,85]. Many of these pathological changes can be mimicked by the adjuvant use of tamoxifen in women with primary breast cancer and are attributed to the direct action of the oestrogens and tamoxifen at the oestrogen receptor to alter cell proliferation and reduce the actions of pro-apoptotic signalling (Figure 4) [86].

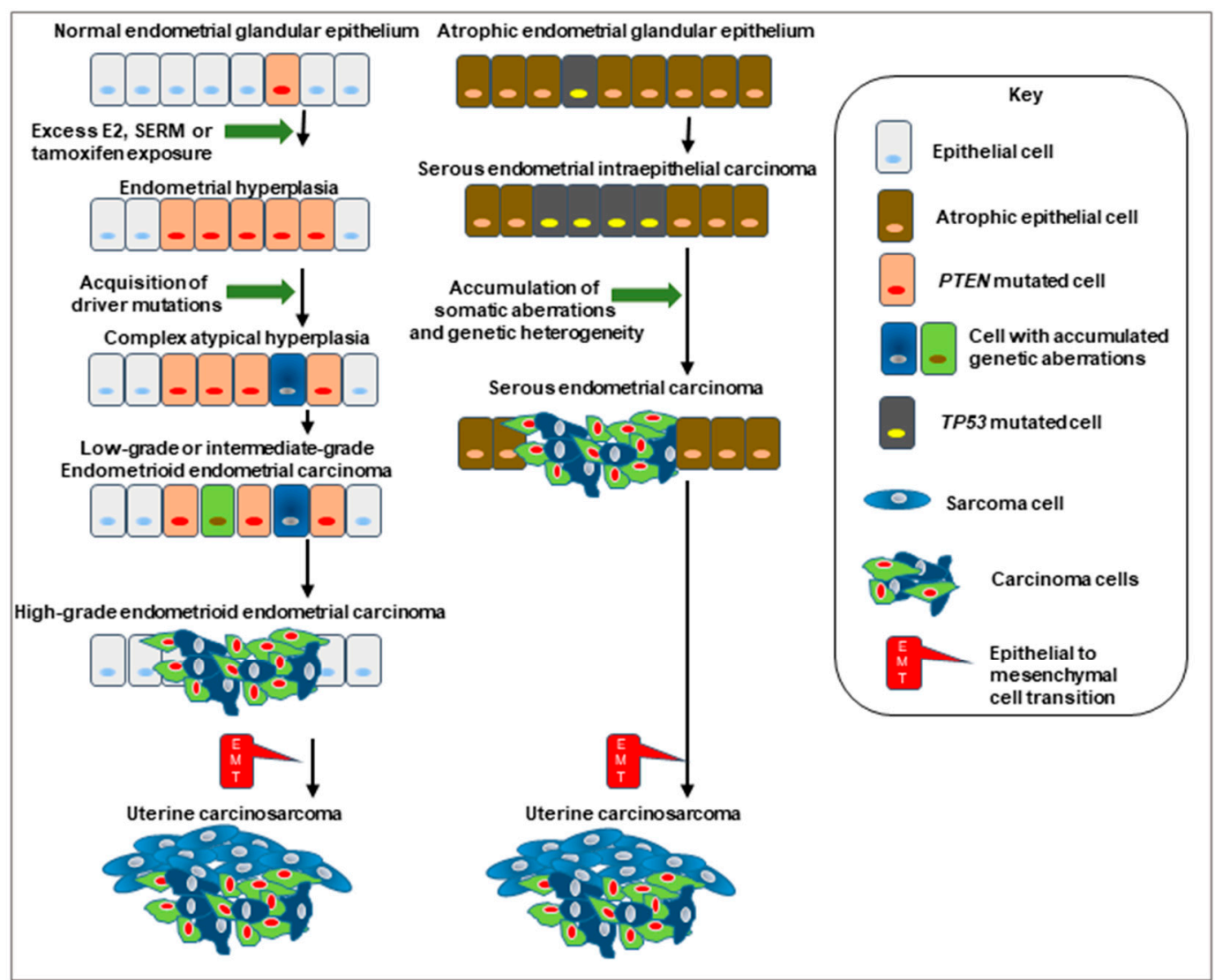

Figure 4. Overview of endometrial cancer origin and development. A schematic representations of the development of and progression of endometrioid (Type 1) EC (left side) and of non-endometrioid serous (Type 2) EC (right side) from their respective normal and atrophic endometrial glandular epithelial cells. During initiation, PTEN or TP53 gene mutations (early events in the aetiopathology of many endometrioid and serous ECs) and other genetic aberrations result in the formation of precursor lesions (complex atypical hyperplasia and serous intratumoural intraepithelial carcinoma, respectively). The epithelial cells that accumulate mutations and genetic alterations are coloured. Sometimes, carcinomas (particularly high-grade tumours) undergo epithelial to mesenchymal cell transition (EMT), giving rise to uterine carcinosarcomas, which as dualistic tumours consist of both epithelial carcinoma cells and sarcoma cells (dark blue and green cells and ovoid blue cells, respectively). Data are adapted from $[70,71]$.

Secondly, extended longevity, resulting in a higher median age for women, results in a promulgation of these effects such that DNA or oxidative damage and other DNA/RNA/ miRNA mutational events accumulate in affected cells and so create the focus for endometrial hyperplasia that is a precursor for the early stage development of EC $[87,88]$. This 
early stage EC (type 1, grade 1) is particularly difficult to detect, as such patients are often asymptomatic.

A third factor is a sedentary lifestyle (Figure 1). As women age, the amount of physical activity they partake in reduces $[4,89,90]$. This reduction in physical activity, can result in a change in body mass, shape and increased deposition of fats and lipids causing obesity [91]. The obesity itself may not be a key determinant in the development of EC, but the increased deposition of lipids in adipose tissue increases the ability of the adipose tissue (especially white fat) to synthesise oestrogens in those peripheral tissues and so increase the levels of circulating oestrogens that can stimulate cells in the uterus [92,93]. In addition, physical activity is thought to decrease the risk for EC because it reduces serum levels of oestradiol by increasing the levels of sex hormone binding globulin (SHBG), the binding protein for oestradiol that is synthesised in the liver. These effects of physical activity may be mediated through prevention of weight gain [90]. More generally, effects on oestrogen metabolism may, at least in part, operate directly, or through decreasing body fat stores [94].

Additionally, a sedentary lifestyle and a daily routine that does not include any physical activity are thought to play a role because increased risk of insulin resistance leading to the development of type 2 diabetes mellitus [95,96]. Type 2 diabetes and the related metabolic syndrome [97,98], are known risk factors for the advancement of EC [99]. It is not only the lack of physical activity that is a contributory factor here, but also the amount of time spent sitting. For example, women who spend the same amount of time being physically active, but actually spend shorter amounts of time sitting, also have reduced risk of developing EC [90,100]. These data suggest that EC risk occurs through insulinrelated mechanisms where low levels of energy expenditure [101] and weight gain [102], factors associated with sitting time [101], are causes of EC development. Conversely, sustained moderate physical activity increases basal metabolic rate and maximal oxygen uptake [103], which in the long term, increases metabolic efficiency and capacity, which reduces circulating insulin levels and insulin resistance [104].

A fourth and final contributory factor, is changes in diet that involve altered absorption and reabsorptions of sterols, since they can alter the regulation and metabolism of oestrogens [105]. This effect is prominent in the gall bladder, where most of the conjugation and excretion of oestrogen is controlled [106,107]. Ingestion of sterols, such as 27-hydroxycholesterol and cholesterol, are also dangerous for women susceptible for EC because they can act as exogenous oestrogens [108] or substrates for oestrogen production [109] and increase endometrial epithelial cell proliferation. Carbohydrates also affect nutrient absorption across the GI tract. For example, increased total dietary carbohydrate intake has been shown to have a modest promoting effect in the development of EC, particularly amongst women who have never used HRT [97]. Long-term consumption of a high carbohydrate diet results in hyperinsulinaemia, which in turn increases the bio-availability of insulin-like growth factor 1 (IGF-1) [110], which directly promotes endometrial epithelial cell growth, reduces cell death and stimulates cell division in EC cell lines [54,111,112]. Insulin and IGF-1 are also powerful negative regulators of sex hormone-binding globulin synthesis in vitro and may therefore stimulate EC development [112], because loss of sex hormone-binding globulin increases the availability of circulating free oestrogens. Polycystic ovary syndrome (PCOS), a hormonal-metabolic disorder, has also been shown to promote EC development providing an approximate 5-fold increased risk [46,54]. PCOS causes excessive production of androgens, which can be converted into oestrogens by the actions of P450 aromatase, which can be found in the endometrium [113] and in omental adipose tissue [114]. This results in excess circulating oestrogen concentrations. Moreover, it has been suggested that the androgens themselves, when present in excess, may increase EC risk directly through activation of the androgen receptor, although this has yet to be clearly established $[115,116]$. The key molecular factor here is the binding of oestrogen to the oestrogen receptor, where it alters the gene expression pattern of the normal endometrial cell to a proliferative phenotype that allows the accumulation of inherent errors of metabolism and DNA replication to be manifest. 


\section{Mechanism of Oestrogen-Independent Endometrial Cancer}

Although most women (80-90\%) present with endometrioid (oestrogen-dependent) $\mathrm{EC}$, there are a minority that present with the most difficult form of EC to treat; Type $2 \mathrm{EC}$ (oestrogen-independent), which tend to be an adenocarcinoma-like tumour but not driven by oestrogen (Figure 4) [38,74,117-119]. These are life-threatening forms of EC [120], that may be a natural progression from endometrioid (Type 1) cancer [22,121], or may have a completely different and distinct aetiopathology [122-124]. The underlying mechanism for the development of Type $2 \mathrm{EC}$ is thought to be due to genetic mutation $[65,125]$ of the tumour suppressor gene TP53 [124,126-129], the tumour suppressor gene PTEN [39] or over-amplification or mutation of HER2-neu, which responds to the actions of epidermal growth factor (Table 3) [130-132].

Because dietary factors, lifestyle and environmental factors are known to affect p53 function in hepatoma cancer (aflatoxin B and hepatitis B [133-136]) and in lung and oesophageal cancer (due to tobacco use [88,137]), it is highly likely that infection and tobacco use could precipitate TP53 mutations in EC too. Furthermore, an increased risk of TP53 gene mutations in breast cancer patients due to extended alcohol consumption has been reported [138-140] and also through increased lycopene/carotenoid intake (found in tomato and pink grapefruit). These two factors are also associated with EC improvement in some studies [141-144], but not all [145]. Some interesting data on the effects of folate suggest a possible treatment for all of these cancers in that folate intake was found to be associated with reduce risk of breast cancer development in women whose tumours had p53 mutations [138]. The authors suggested a direct causal link between alcohol intake and p53 mutation concluding that increased alcohol consumption inhibits folate uptake from the diet [138]. Since folate protects against TP53 mutagenesis, then excess alcohol consumption puts women at risk of developing p53 mutations, and that leads directly to the development of breast and other cancers. Another factor that needs consideration is a Western diet, which consists of a high glycaemic index (amount of sugar absorbed into blood over $2 \mathrm{~h}$ ), red meat and processed food that is known to contribute to colon cancer development, also through a TP53 missense mutation [146,147]. These data suggest that a Western diet full of carbohydrates, red meat, alcohol and processed food could cause type 2 EC directly through p53 mutations.

Diabetes mellitus and hyperinsulinaemia are associated with EC [148-151]. Diabetic postmenopausal women are twice as likely to develop EC as their non-diabetic counterparts [152]. In addition, type 2 diabetics often develop insulin resistance, which results in hyperinsulinaemia, a metabolic state that adds additional EC risk [153]. Moreover, a low level of the hormone adiponectin, which may be a surrogate marker for insulin resistance, has also been associated with increased EC risk in some but not all studies $[25,154,155]$. Similar to what occurs in healthy cells during diabetes and insulin resistance, EC cells develop abnormalities in the insulin and insulin-like growth factor-1 (IGF-1) signalling pathways, both of which are involved in cancer cell growth. Thus, it is not surprising that the anti-diabetic drug metformin, which improves insulin sensitivity, has received considerable attention from researchers investigating new ways to combat EC [25,155-158]. Metformin is a drug that lowers blood glucose levels by reducing the ability of the liver to produce new glucose from glycogen and also increases the ability of muscle cells to take up glucose from the blood $[159,160]$. A variety of epidemiological studies have shown that diabetic patients taking metformin are significantly less likely to develop a variety of cancers, including those of the pancreas, liver, colon-rectum, and breast [161-165]. With respect to EC, preclinical studies have shown that metformin inhibits the proliferation and promotes the death of EC cells $[156,166,167]$.

There are also hereditary syndromes that affect the gastrointestinal tract that predispose some women to simultaneous or later development of EC (Figure 5). Many of the genetic factors that induce EC are also responsible for these hereditary syndromes (Figure 5). Although the causes of these syndromes is still being undertaken, it is important 
to note here that the POLD1 mutation is now known to be associated with increased risk of EC but the POLE mutation seems to be protective $[63,70]$.

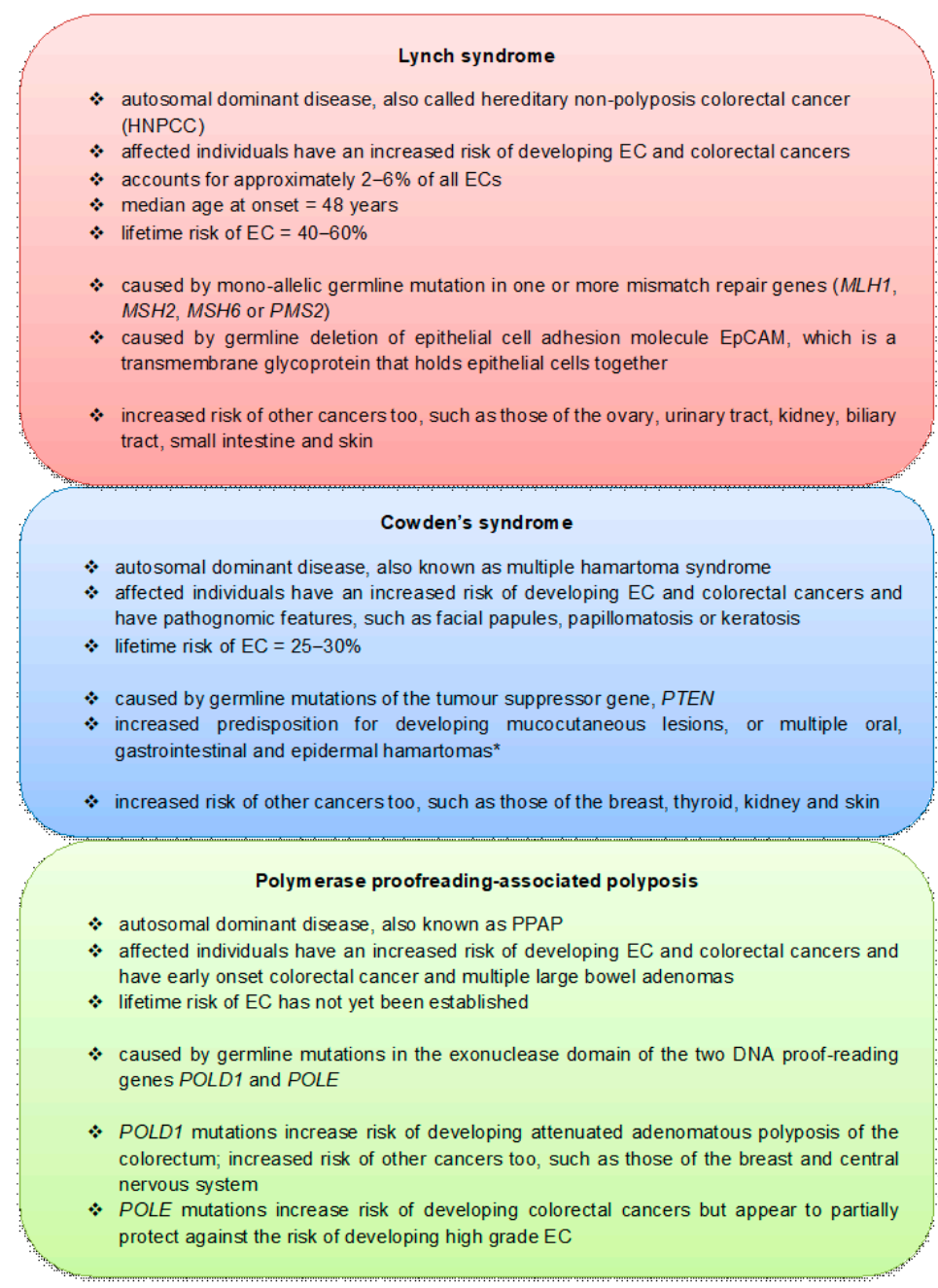

Figure 5. Hereditary syndromes manifesting as increased risk of developing EC. Each of these diseases is inherited in an autosomal dominant manner and each is a non-modifiable risk factor for the development of EC. The mismatch genes, MutL Homolog 1 (MLH1), MutS Homolog 2 (MSH2), MutS Homolog 6 (MSH6) and PMS1 Homolog 2, Mismatch Repair System Component (PMS2) are all component parts of the post-replicative DNA mismatch repair system (MMR) that coordinately repairs double stranded DNA errors. Mutations of these genes prevents DNA repair. * A hamartoma is a tumour-like, non-neoplastic disordered proliferation of mature tissue.

\section{How Metformin and Progestin Protects against EC}

Prominent mechanisms by which metformin combats EC appear to be through promotion of progesterone receptor expression and the reversal of progestin resistance [166,167]. Since EC is largely an oestrogen-driven disease, one of the treatments used is to administer progesterone or synthetic progestins, which counter the action of oestrogen in the endometrium. However, a major hurdle for this treatment approach is that the expression of the target for progesterone and synthetic progestins, the progesterone receptor, is sometimes downregulated in EC cells, especially following long-term treatment with a synthetic progestin or in patients with Type 2 EC. This negates the effects of progesterone or synthetic progestins, even if ample concentrations are available [168]. The simultaneous administration of metformin and the synthetic progestin medroxyprogesterone acetate (MPA) decrease proliferation of EC cells in culture [166], whereby metformin increased progesterone receptor expression allowing a place for MPA to bind. The MPA presum- 
ably inhibited oestrogen receptor alpha expression and so prevented oestrogen-dependent cell proliferation [169] although this was not studied. Similarly, Zhang and colleagues in 2011 demonstrated that metformin not only reversed progestin resistance in their model system but inhibited cell proliferation and induced apoptosis (programmed cell death) in progestin-resistant EC cells [167].

Natural progesterone also exerts several anti-cancer effects in endometrial tissue, primarily related to cell differentiation. In one experimental study, administration of progesterone to EC cells reduced cancer cell proliferation by activating the metabolic regulators p21 and p27 [170]. In addition, treatment with progesterone led to a reduction in the expression of several cellular adhesion molecules that cancer cells use to attach to normal tissues and spread [170]. In one study that followed 12 women with stage 1 , grade 1 , type $1 \mathrm{EC}$ for up to 36 months, placement of a progesterone-containing intrauterine device resulted in negative biopsies at 12 months in 6 of 8 patients [171]. Progesterone also reduces the expression of the alpha form of the oestrogen receptor, which is major proliferation stimulator in EC cells [172]. Indeed, when the receptor is missing, activation of the beta form of the oestrogen receptor appears to inhibit EC cell proliferation [173].

Progesterone also augmented the anti-tumour effects of vitamin D by upregulating the expression of the vitamin D receptor in EC cells [174], whilst simultaneous administration of a metabolically active form of vitamin D (1,25-dihydroxyvitamin D3) and progesterone led to a significant upregulation of proteins that help restrain tumour growth and metastasis in EC cells [175]. These results suggest that women undergoing progesterone therapy for EC may be able to achieve a more desirable outcome by ensuring their blood levels of 25-hydroxyvitamin D are in the optimal range. Although studies have yet to test this hypothesis thoroughly, one effect may be to induce apoptosis through the reduction of reactive oxidative species [176]. Nevertheless, it is known that women in hotter, sunnier regions of the world have lower incidence of $\mathrm{EC}$ when compared to those from cooler, less sunny environments [40,41], suggesting this observation may be correct (the sun converts ingested vitamin D into the metabolically active form [177]). Additionally, complete covering of the skin for cultural or religious reasons can also reduce vitamin D levels and increase EC risk, suggesting a causal link [178].

\section{Dietary Factors}

EC appears to be especially influenced by dietary and lifestyle factors [24] with a variety of factors related to diet and lifestyle increasing the chances of developing EC; chief among them is the consumption of foods high in animal fats and sugars, whereas diets high in vegetables and fruits (especially those high in lutein) have lower risk [31,34,143,179,180]. High intake of iron from red meat has also been modestly associated with increased risk [181-183]. Since dietary factors are implicated in the development of EC, it is important to examine some of these factors in turn, starting with lipids.

\section{Lipids}

Dietary omega fatty acid composition increases the risk of developing several diseases, including cardiovascular disease and cancer. There are two primary omega fatty acids: omega-3 lipids and omega-6 lipids, differentiated by their chemical structure. Omega-3 lipids are generally viewed as exerting anti-inflammatory action, whereas their omega-6 counterparts are easily metabolised into pro-inflammatory end products [184]. Given that inflammation plays a major role in tumour initiation and survival, omega-3 fatty acids have gained considerable attention in the context of cancer prevention and treatment [185]. Indeed, evidence suggests a higher dietary omega- 3 to omega- 6 ratio is associated with a lower risk of EC [186]. For example, in a study of 556 women with EC and 533 healthy controls whose consumption of the omega-3 lipids eicosapentaenoic acid (EPA) and docosahexaenoic acid (DHA) recorded a significantly lower EC risk. These are often found at high concentrations in cold water fish, and the women in the top $25 \%$ who ate fish rich in EPA had a $43 \%$ lower risk of developing EC, when compared with the women in the 
lowest $25 \%$. Similarly, those consuming the most DHA had a $36 \%$ lower risk compared to those consuming the least, whilst a ratio of omega- 3 to omega- 6 fatty acids in a diet was associated with reduced EC risk. Finally, those women who consumed fish oil supplements had a 37\% lower risk of EC [186]. A larger study of more than 3500 women found that eating fatty fish (which also contain high concentrations of omega- 3 fatty acids) had a $40 \%$ lower EC risk [183]. These omega-3 fatty acids are thought to prevent cancer development by altering gene expression, oestrogen metabolism, and by causing improved insulin sensitivity and reduced inflammation $[186,187]$. This suggests that consumption of oily fish or supplementation of diets with a high omega- 3 to omega- 6 ratio would be beneficial. The source of that omega- 3 may be of some concern since some sources may be contaminated with toxic/carcinogenic compounds that adversely affect the development and progression of other cancer types [188].

One of the healthiest eating styles in the world is the so-called "Mediterranean diet", a traditional dietary pattern of populations of the Mediterranean region that includes the Southern European states, the North African states and those of the western fringes of the Middle East [189]. This diet centres upon whole grains, vegetables, fruits, olive oil, fish, and is combined with moderate dairy and wine consumption. The Mediterranean diet reduces the risk of several of today's most prominent ailments including obesity, cardiovascular disease, and cancer [190,191]. Accordingly, rates of EC in the Mediterranean region are lower than in the United States and United Kingdom [40,41], and other 'Westernised' societies (Figure 2), and this effect is thought to be caused, at least in part, to differences in diet within these regions. In fact, it has been estimated that $10 \%$ of EC cases could be prevented if "Western" societies shifted to a more Mediterranean-like diet, one with less red meat and animal fat [192]. In one study, adherence to a "Western" diet, which is high in saturated and animal fats (as well as refined carbohydrates), was associated with a $60 \%$ increased risk of developing EC [193], whilst another study of Italian women consuming a Mediterranean diet with low adherence showed an approximate doubling in EC risk compared to a control cohort that had high adherence rates, with an increased dietary inflammation index (the consumption of foods with inflammatory properties such as red meat and processed meats) being the intermediary cause [194]. Indeed, a meta-analysis of available data from case-control studies on the risk of developing EC due to the consumption of red meat concluded that higher red meat consumption of $100 \mathrm{~g}$ per day increased EC risk by $84 \%$ [195]. By contrast, the same authors reported there to be no association in prospective observational studies, suggesting that an association of EC with red meat consumption is probable rather than absolute. Indeed, in a meta-analysis of multiple studies, a $51 \%$ increased EC risk was associated with red meat consumption but there was no association with white meat (chicken) or fish consumption [196] supporting the idea that a Mediterranean-like diet would be beneficial. Other cohort studies, e.g., the Iowa Women's Health Study indicated no association between red meat consumption and EC risk [197]. This provides inconclusive evidence for a causative role of red meat consumption in the risk of developing EC. However, it should be pointed out that analyses from this cohort also failed to find an association between red meat and colorectal cancer, which has generally been supported by other cohort studies to be an important association $[198,199]$. All of these disparate studies have provided a less than ideal understanding on whether red meat or processed meat consumption is a 'true' risk factor for the development of EC and that a vegan or vegetable/vegetarian-only diet may be preventative of EC development. Current knowledge, however, does not support that hypothesis [200]. The EPIC-Oxford trial, which ran from 1993 to 2005 demonstrated that the incidences of ovarian, uterine, endometrial and breast cancers were not significantly different to their omnivore counterparts, even when fish was allowed to be part of the vegetarian diet [201,202]. Additionally, the Adventist Health Study of Californian vegan/vegetarians that ran from 1976 to 1982 indicated a modest 15\% reduction in EC risk, although the risk difference was not significant (OR 95\% CI range was 0.58 to 1.23) [203]. The available data so far suggests that a more vegetable-fruit based diet may be more protective against the development of EC, but data supporting 
a recommendation along these lines for EC protection remains elusive. To reduce red meat intake and to eat more fruit and vegetables (in moderation) is supported, since doing so prevents other forms of cancer and prevents other life-threatening diseases [203-208], presumably because doing so reduces an individual's body mass and changes body composition whilst providing essential vitamins and minerals that cannot be obtained from meat products $[209,210]$.

\section{Vitamins and Minerals}

\subsection{Vitamin $A$ and Carotenoids}

Vitamin A is an essential vitamin that is found in plants and stored in the liver. It is part of a family of pigments found in plants called the carotenoids, which are normally yellow. The most well know of the carotenoids is called beta-carotene, which under the actions of bile acids is converted in retinal, then into the active form of vitamin A. Vitamin A and some vitamin A derivatives, are active at retinoic acid receptors where they act as transcriptional regulators [211]. On activation, retinoic acid receptors alter the transcription of many genes involved in inhibiting tumour growth and invasion, through inhibition of carcinogenesis and induction of programmed cell death (apoptosis) [212,213]. Increased ingestion of vitamin A or $\beta$-carotene is associated with a lower risk of developing EC $[143,179,214,215]$. When consumption of beta-carotene is combined with vitamin $C$, the risk of developing EC is halved [216]. It is for this reason that all cancer patients are often advised to increase their consumption of vegetables that are yellow and orange [215], even though conclusive evidence is still lacking [217]. Preclinical studies of some carotenoids have demonstrated that they can synergistically affect the therapeutic potential of some anti-cancer drugs. For example, the carotenoid, fucoxanthin enhances the cytotoxicity of doxorubicin in multi-drug resistant breast cancer cells [218], suggesting that certain vitamin-therapeutic combinations could be more effective in preventing some forms of neoplastic recurrence. A corollary to that idea is that some carotenoid treatments may affect other tissues, such as bone whilst also protecting against breast and EC neoplasia [219]. More research into the effects of vitamin A and the carotenoids would therefore be useful.

\subsection{Vitamin C}

As stated above, vitamin C may aid in the prevention of EC. This vitamin (ascorbic acid) has been reported in many studies to significantly reduce the risk of developing EC $[28,32,214,220-222]$. Vitamin C has been proposed to reduce the activity of a key protein called hypoxia inducible factor- 1 alpha (HIF-1 $\alpha$ ), which is involved in endometrial tumour cell survival [221,223]. Although vitamin $C$ has direct effects on tumour cells, it also may have an effect on tumour biology by modulating the actions of the immune system, in which tumour cell surveillance is improved and tumour cell killing is enhanced [224]. Increased vitamin C consumption not only reduces EC incidence, but prevents the advancement to more aggressive disease grades [214,220,221]. In 2009, Bandera and colleagues demonstrated that only $50 \mathrm{mg}$ vitamin C per 1000 calories consumed reduced EC risk by $15 \%$ [220]. A higher level of vitamin C ( $\geq 72.7 \mathrm{mg}$ of vitamin C per 1000 calories/day) reduced EC risk by $20 \%$. Women in the lowest consumption group ( $\leq 29.8 \mathrm{mg}$ per 1000 calories/day) had the highest EC risk [214]. These data suggest that foods rich in vitamin C, such as cauliflower, kale, pineapple, sweet potato, bell peppers, peas, legumes, strawberries and citrus fruits should be part of the daily diet [4,225]. In a meta-analysis of numerous observational studies, vitamin $\mathrm{C}$ consumption was able to reduce breast cancer incidence by $11 \%$ when part of the daily diet, but a similar effect with vitamin $C$ supplements was not [226]. More importantly, the study also showed that breast cancer recurrence remained lower in the higher vitamin C consumption group when compared with the lowest consumption group [226]. These observations have been confirmed in several other recent studies where vitamin $C$ appears to enhance both radio- and immuno-therapy regimens, possibly through alterations in the neutrophil-macrophage ratio [227-230]. Similar data for patients with EC are lacking, but the recent demonstration of a similar effect of vitamin D 
(an effector for the immune system) on EC outcomes [231,232], suggest that vitamin C or D consumption may be beneficial for many forms of cancer [233] including EC. Indeed, this idea was proposed many years ago [234].

\subsection{Vitamin $E$}

It is now clear that in vitamin $\mathrm{E}$ consumption results in a significantly reduced risk of developing EC [214,215]. Many foods contain significant amounts of vitamin E. Wheat germ and other seed bearing oils contain the highest amounts of vitamin E. Nuts such as almonds, hazelnuts, pine nuts and sunflower seeds, which are moderately high in vitamin $\mathrm{E}$, and vegetables such as sweet red peppers, tomatoes and spinach contain lower, but significant levels of vitamin E, but each should be part of the vitamin diet. High intakes of vitamin E has been reported to cause a 56\% reduction in EC risk [215]. Despite these data, larger prospective cohort studies of 87,998 women in the Nurses' Health Study and 47,344 men in the Health Professionals Follow-up Study failed to replicate these results [235]. Although some research links higher intakes of vitamin E with decreased incidence of breast cancer, an examination of the impact of dietary factors, including vitamin $\mathrm{E}$, on the incidence of postmenopausal breast cancer in >18,000 women found no benefit from the vitamin [236].

Vitamin E naturally occurs in more than one form, with each form having a different level of biological activity) [237]. Of the eight chemical forms (alpha-, beta-, gamma-, and delta-tocopherol and alpha-, beta-, gamma-, and delta-tocotrienol, only gamma-tocopherol had a significant anti-inflammatory and anti-tumour effect in a rat model of breast cancer [238]. This is of interest when considering EC development and risk because gammatocopherol appeared to work through inhibiting oestrogen activity in other gynaecological cancers and so inhibits tumour growth. For example, Korean women who consumed higher amounts of gamma-tocopherol showed a $72 \%$ lower risk of developing ovarian cancer compared to women who have not [239]. Although the effect of vitamin E and other anti-oxidant vitamins on the prevention of DNA damage is modest [240], they do have a contributory role in cancer prevention [241-243] that is starting to be exploited therapeutically [244].

\subsection{Selenium}

Selenium is an essential micronutrient required for numerous metabolic processes throughout the body [245]. Gynaecological cancers, such as those of the uterus and cervix are less prevalent in women exposed to higher levels of selenium than those who have low level exposure $[246,247]$. In 2009, a randomised prospective clinical trial showed sodium selenite supplementation to be advantageous for cervical and uterine cancer patients who had selenium deficiency, because it reduced the diarrhoea caused by radiotherapy treatment [248]. Selenium supplementation may be particularly useful for cervical cancer patients, because in vitro studies have shown that sodium selenite induces cervical cancer cell apoptosis [249]. Other studies have shown that selenium can disrupt oestrogen signalling in cancer cells [250]. Furthermore, additional more recent in vitro studies have revealed that selenium can also act together with vitamin $C$ to prevent tumour cell growth in both breast and colon carcinoma cell lines [241,251,252]. Nevertheless, more studies in this area are needed and assessment of the daily therapeutic level for the prevention of EC is required.

\subsection{Calcium}

Everybody knows that calcium is good for healthy teeth and bone. It is found in many dairy products and in its ionic form is intimately involved in the release of hormones from endocrine glands, neurotransmitters from nerves, initiating muscle contraction, and for maintaining bone [253]. It is also a critical component of protein kinase C (PKC) signalling, which controls many cellular growth and apoptosis pathways [254]. Cellular differentiation and proliferation must be carefully regulated otherwise cancers develop 
and calcium plays a critical role in controlling many of the metabolic pathways here [255]. The risk of developing EC is greatly reduced in women taking calcium supplements or who consume calcium-rich foods. Dairy foods such as milk, cheese and yoghurt, and non-dairy products such as seafood, leafy greens, legumes, dried fruit and tofu have all been shown to significantly reduce EC risk $[36,183,256]$, suggesting that research into calcium supplementation in the prevention and potential treatment of EC would be useful as it is for Korean breast cancer survivors who show longer survival when supplements containing calcium are consumed [257].

\subsection{Cadmium}

Cadmium is a chemical element that is ubiquitous in Nature and is found in air, water, soil and plants. It is also extracted from rocks and processed in order to make the expanding nickel-cadmium (Ni-Cd) battery industry. These batteries are increasingly used in many modern electronic devices. Exposure to cadmium is greater in industries where it is processed and ingested from contaminated hands, from plants that absorb it from the environment, or from cigarette smoking [258]. In the context of cancer, cadmium exposure has been associated with lung, kidney and prostate cancer $[259,260]$. It is also been associated with decreased EC risk due to the actions of the $\mathrm{Cd}^{2+}$ ion which acts a weak oestrogen [261,262], binding to and preventing the actions of oestrogen receptor alpha [263]. Studies have indicated that smoking per se protects against EC $[264,265]$ in both prospective and case-control studies, which showed the greatest decrease of risk occurred in heavy smokers over increasing years of use [266]. By contrast, other oestrogenspecific cancers, such as ER-positive breast cancer is not protected nor exacerbated by $\mathrm{Cd}^{2+}$ ions [267] despite in vitro studies that indicate it may increase breast cancer cell malignancy through a decreased dependency on oestrogen-stimulated cell proliferation [268]. Despite this potentially beneficial effect of cigarette smoking for women at risk of developing $\mathrm{EC}$, the other detrimental health effects (cardiovascular disease, tumour formation in the respiratory tract and lungs, etc.) outweigh this potential benefit.

In conclusion, the role of vitamins and minerals in providing protection against $\mathrm{EC}$ is only partially supported by scientific consensus $[36,37]$ and although the evidence is scant, more detailed studies in this interesting area should help to clarify the role(s), if any, of these essential micronutrients in the near future [200].

\section{Plant Derivatives and Hormones}

\subsection{Lignans}

Phytoestrogens have long been known to ameliorate perimenopausal symptoms and have significant health benefits in postmenopausal women. The key natural phytoestrogens found in plants such as flaxseed and sesame are the lignans [269]. The active ingredient in such foods are not the lignans themselves, but their metabolised product, enterolactone. This compound has two important effects in cancers, (1) it promotes cancer cell death and (2) prevents the growth of new blood vessels in hormone-responsive tumours thereby prevents the tumour's capacity to allow cancer cells to grow [270]. It has been postulated that phytoestrogens may compete with endogenous oestrogen for binding at the oestrogen receptor [271,272], which is logical since the most common form of EC is type $1 \mathrm{EC}$, which is oestrogen-dependent. Thus, studies showing high lignin consumption in all types of women have a $32 \%$ lower risk of developing EC, support this hypothesis. It is further supported by a study in postmenopausal women, where EC risk was $43 \%$ lower [273]. It has been historically impossible to recommend phytoestrogen consumption to postmenopausal women, since such consumption might also induce breast cancer in oestrogen receptor positive neoplasms, however, several studies have shown this idea to be unfounded and that the phytoestrogen enterolactone is protective against breast cancer too [274-276]. 


\subsection{Soy Isoflavones}

Soya beans and other legumes contain significant amounts of isoflavones, as do green tea, red clover, lentils and flaxseeds. Increased ingestion of such food results in lower EC risk [277]. Postmenopausal women were significantly less likely to develop EC if they consumed more soy isoflavones (including genistein and daidzein) and total isoflavones [277]. Additionally, a lower risk of developing EC has been reported in several case-control studies where soy and legume consumption was high $[180,278,279]$. Soy isoflavones bind to oestrogen receptors and modulate intracellular oestrogen signalling, whereby they are similar to lignans and compete with endogenous oestrogens, to reduce endogenous oestrogenic activity $[272,280]$, however, three recent studies have shown that soy ingestion may increase the risk of developing breast cancer [21,281,282], whilst ovarian cancer risk was reduced [283]. So far, available evidence does not point to any dangers from consuming soy, with general health benefits appearing to outweigh any potential risk [284]. In fact, there is growing evidence that eating traditional soy foods such as tofu, tempeh, edamame, miso, and soymilk from an early age may lower the risk of developing EC and breast cancer, especially among Asian women $[285,286]$. Soy foods are excellent sources of protein, especially when they replace other, less healthy sources, such as animal fats and red or processed meats. The reason why some studies have shown an increased risk of developing breast cancer through ingestion of isoflavones [281,287], whilst other studies have not confirmed such associations or have shown the opposite $[179,180,277,279,283,285,286,288,289]$, is probably due to the presence of the oestrogen receptors in the starting neoplasm [281], the population under study [290] or the physical form that the isoflavone that is consumed [288,291]. Meta-analyses of different studies in various populations generally support the idea that moderate to high consumption of a diet that contains isoflavones prevents EC, ovarian and breast cancer and its recurrence [283,292-294]. These data suggest that a diet rich in isoflavones or that concentrated soy supplements, which contain much higher isoflavone concentrations will be beneficial, but until more research is done with pre- and peri- and postmenopausal cohorts, a definitive conclusion cannot be met.

\subsection{Coffee and Chlorogenic Acid}

Coffee consumption has been linked with a reduction in the development of all types of oestrogen-driven cancers, including EC [295-301], where drinking at least four cups of coffee per day causes a $25 \%$ reduction EC risk when compared to drinking one cup or less per day. Interestingly, because drinking equivalent amounts of decaffeinated coffee per day (two or more cups) was associated with a $22 \%$ reduction in EC risk [302], then the effect is not due to the presence of caffeine or its primary metabolites, but due to other constituents of the coffee bean. When the bean is ground and filtered, EC rates dropped, if the ground bean is boiled then EC rates increased [303]. These data suggest that modest coffee consumption could be beneficial in the prevention of EC, however, what effect, if any coffee consumption has on progression or disease recurrence is currently unknown. Conversely, drinking brewed or instant coffee has been associated with an increased risk of developing breast cancer in some [304,305] but not all studies [306] and has no effect on the incidence of ovarian cancer [307]. In these studies, it appears that exposure of the coffee bean or its processed products to heat is a preventative factor, since instant and boiled coffee showed a 50\% reduction in the risk of developing breast cancer, whilst filtered coffee seems to have the opposite effect, especially in premenopausal women of normal weight [303,305]. Paradoxically filtered coffee has the opposite effect in postmenopausal women, where there was a $40 \%$ reduced risk of developing breast cancer, but an increased risk if the coffee was instant or boiled [303], suggesting that patients at risk of developing endometrial cancer (who are generally postmenopausal) should drink moderate amounts (no more than three cups) of filtered coffee per day [301]. Although coffee contains multiple phytochemicals and polyphenols that exert various physiological effects, the polyphenol chlorogenic acid (CGA), is the probable active ingredient in respect to EC protection since it may protect cells from oxidative DNA damage [308]. Although CGA concentrations 
are moderate in brewed coffee, it is highly concentrated in green coffee bean extracts, explaining the protective effect of filtered coffee over brewed or instant coffee. The coffee bean and its extracts may also have indirect effects in preventing EC, since it inhibits insulin production, improves insulin resistance [309] and so is beneficial to EC patients because it prevents weight gain and modulates glucose metabolism [30,302,310]. Obviously, such observations need corroboration in larger studies and all forms of cancer need to be considered, especially as boiled coffee is associated with respiratory tract cancers in men [303]. That this final effect is confined to men, suggests a gender-specific factor is interacting with a component in coffee to induce or exacerbate the neoplasms found in men, whilst a different gender-specific factor is protective in women.

\subsection{Green Tea and (-)-Epigallocatechin-3-Gallate}

Drinking green tea has historically been associated with reduced incidence of many cancers [311,312]. The major polyphenol found in green tea, epigallocatechin-3-gallate (EGCG), was reported by Kakuta and colleagues to be effective against EC, and that effect was independent of other EC risk factors such as obesity or menopause [313]. In preclinical studies, EGCG inhibits EC cell proliferation and induces cell death [314] and in a single animal study, EGCG inhibited angiogenesis [315], thereby preventing the formation of new blood vessels that support large tumours. Interest in this has expanded and a meta-analysis of 7 published studies reported that the protective effect of green tea was better than that of black tea and that a $25 \%$ decrease in EC risk could be achieved by drinking an additional 2 cups of green tea per day [316] (Table 4). More recent evidence using a xenograft model indicated that the use of a prodrug form of EGCG inhibited tumour cell proliferation and increased apoptosis in a time- and dose-dependent manner [317]. One effect was that microvessel formation was decreased, thereby reducing blood flow to the xenograft. Similar effects were observed in a mouse model of ovarian cancer [318], suggesting that careful use of such extracts could be useful for the prevention of numerous neoplasms.

Table 4. Risk factors tested in patients with endometrial cancer and analysed through meta-analysis or Cochrane review.

\begin{tabular}{|c|c|c|c|c|}
\hline Factor & Ref & Studies Included & $\begin{array}{l}\text { Odds Ratio or Relative Risk } \\
\qquad(95 \% \mathrm{CI})\end{array}$ & Direction of Risk \\
\hline \multirow{2}{*}{ Alcohol $^{\mathrm{a}}$} & [319] & 14 case-control & $0.89(0.76-1.05)$ & No effect \\
\hline & [320] & 7 cohort design & $1.17(0.93-1.46)$ & No effect \\
\hline \multirow{3}{*}{ Aspirin $b$} & \multirow{3}{*}{ [321] } & 5 case-control & $0.82(0.71-0.96)$ & \multirow{3}{*}{$\begin{array}{c}\downarrow \\
\text { No effect } \\
\downarrow\end{array}$} \\
\hline & & 4 cohort design & $0.91(0.80-1.03)$ & \\
\hline & & Overall & $0.87(0.79-0.96)$ & \\
\hline Beast feeding & [322] & $\begin{array}{l}4 \text { prospective and } 10 \\
\text { retrospective studies }\end{array}$ & $0.77(0.62-0.96)$ & $\downarrow$ \\
\hline Body mass index ${ }^{c}$ & [323] & Randomised clinical trial & RR 19.03 (1.17-310.52) & $\uparrow$ \\
\hline Cadmium $^{\mathrm{d}}$ & [324] & 4 cohort design & $1.40(1.06-1.84)$ & $\uparrow$ \\
\hline Calcium & [255] & 3 case-control & $0.62(0.42-0.93)$ & $\downarrow$ \\
\hline \multirow{2}{*}{ Cholesterol } & \multirow{2}{*}{ [109] } & 9 case-control & $1.07(1.01-1.13)$ & $\uparrow$ \\
\hline & & 1 cohort design & $1.06(1.00-1.12)$ & $\uparrow$ \\
\hline \multirow{2}{*}{ Cigarette Smoking } & \multirow{2}{*}{ [325] } & 24 case-control & $0.72(0.66-0.79)$ & $\downarrow$ \\
\hline & & 10 prospective & $0.81(0.74-0.88)$ & $\downarrow$ \\
\hline \multirow{3}{*}{$\begin{array}{c}\text { Coffee } \\
\text { (caffeinated vs. } \\
\text { de-caffeinated) }\end{array}$} & \multirow{3}{*}{ [326] } & \multirow{3}{*}{$\begin{array}{l}10 \text { case-control } \\
4 \text { cohort design }\end{array}$} & $0.79(0.73,0.87)$ & $\downarrow$ \\
\hline & & & $0.65(0.50,0.85)^{\mathrm{e}}$ & $\downarrow$ \\
\hline & & & $0.76(0.62,0.93)^{\mathrm{f}}$ & $\downarrow$ \\
\hline Dairy products & [196] & 8 case-control & $0.97(0.93-1.01)$ & No effect \\
\hline \multirow{2}{*}{ Green tea } & [316] & 7 case-control & $0.78(0.66-0.92)$ & $\downarrow$ \\
\hline & [327] & 6 cohort design & $0.97(0.82-1.14)$ & No effect \\
\hline
\end{tabular}


Table 4. Cont.

\begin{tabular}{|c|c|c|c|c|}
\hline Factor & Ref & Studies Included & $\begin{array}{l}\text { Odds Ratio or Relative Risk } \\
\qquad(95 \% \mathrm{CI})\end{array}$ & Direction of Risk \\
\hline \multirow{3}{*}{ Insulin resistance $\mathrm{g}$} & \multirow{3}{*}{ [328] } & 2 case-control & $37.52 \mathrm{pmol} / \mathrm{L}(16.64-58.40)$ & $\uparrow$ \\
\hline & & 2 prospective & $33.94 \mathrm{pmol} / \mathrm{L}(15.04-52.85)$ & $\uparrow$ \\
\hline & & 21 cross-sectional & $21.25 \mathrm{pmol} / \mathrm{L}(1.45-41.05)$ & $\uparrow$ \\
\hline Lignans & [329] & 3 case-control & $0.92(0.71,1.20)$ & No effect \\
\hline \multirow{2}{*}{ Lipids } & \multirow{2}{*}{ [330] } & 14 case-control & $1.21(1.01-1.45)$ & $\uparrow$ \\
\hline & & 7 cohort & $0.91(0.83-1.01)$ & No effect \\
\hline \multirow{5}{*}{ Metabolic syndrome } & \multirow{5}{*}{ [331] } & 3 case-control & $2.45(1.81-3.08)$ & $\uparrow$ \\
\hline & & 1 nested case-control & $1.62(1.08-2.42)$ & $\uparrow$ \\
\hline & & 1 prospective & $1.37(1.28-1.46)$ & $\uparrow$ \\
\hline & & 1 cohort registry & $2.77(1.74-4.40)$ & $\uparrow$ \\
\hline & & Overall & $1.89(1.34-2.67)$ & $\uparrow$ \\
\hline \multirow{2}{*}{ Oestrogen only HRT } & [27] & 1 case-control & $1.45[1.02-2.06]$ & $\uparrow$ \\
\hline & [332] & 30 cohort design & $2.30(2.10-2.50)$ & $\uparrow$ \\
\hline Oestrogen plus progestagens HRT & [332] & 30 cohort design & $0.40(0.20-0.60)$ & $\downarrow$ \\
\hline \multirow{4}{*}{ Overweight/Obesity ${ }^{\mathrm{h}}$} & \multirow{4}{*}{ [333] } & 8 case-control & $1.18(0.96-1.45)$ & No effect \\
\hline & & 6 cohort design & $1.47(1.22-1.78)$ & $\uparrow$ \\
\hline & & 8 case-control $^{h}$ & $2.06(1.61-2.63)$ & $\uparrow$ \\
\hline & & 6 cohort design $h$ & $3.11(2.62-3.69)$ & $\uparrow$ \\
\hline \multirow{2}{*}{ Physical activity } & \multirow{2}{*}{ [334] } & 14 case-control & RR $0.72(0.64-0.80)$ & $\downarrow$ \\
\hline & & 19 cohort design & RR $0.84(0.78-0.91)$ & $\downarrow$ \\
\hline Red Meat & [196] & 7 case-control & $1.60(1.26-2.03)$ & $\uparrow$ \\
\hline \multirow{2}{*}{ Saturated fatty acids } & \multirow{2}{*}{ [335] } & 10 case-control & RR 1.06 (0.98-1.14) & No effect \\
\hline & & 4 cohort design & RR 0.97 (0.93-1.00) & No effect \\
\hline \multirow{2}{*}{ Selenium } & [336] & 1 case-control & $0.74(0.47-1.17)$ & No effect \\
\hline & [337] & 1 cohort design & $0.90(0.53-1.50)$ & $\downarrow$ \\
\hline \multirow{2}{*}{ Soy isoflavones } & \multirow{2}{*}{ [329] } & 5 case-control & $0.82(0.69,0.97)$ & $\downarrow$ \\
\hline & & 2 prospective & $0.80(0.51,1.26)$ & No effect \\
\hline \multirow{2}{*}{ Vitamin $\mathrm{A}^{\mathrm{i}}$} & \multirow{2}{*}{ [220] } & 12 case-control & $0.88(0.79-0.98)$ & $\downarrow$ \\
\hline & & 1 cohort & $0.94(0.84-1.05)$ & No effect \\
\hline \multirow{2}{*}{ Vitamin C } & \multirow{2}{*}{ [220] } & 12 case-control & $0.85(0.73-0.98)$ & $\downarrow$ \\
\hline & & 1 cohort & $1.01(0.79-1.28)$ & No effect \\
\hline Vitamin D & [220] & 3 case-control & $0.85(0.34-2.13)$ & No effect \\
\hline \multirow{2}{*}{ Vitamin E } & \multirow{2}{*}{ [220] } & 12 case-control & $0.91(0.84-0.99)$ & $\downarrow$ \\
\hline & & 1 cohort & $1.06(0.82-1.37)$ & No effect \\
\hline
\end{tabular}

${ }^{\mathrm{a}}$ Women who drank $<13 \mathrm{~g}$ of alcohol per day had a small reduced risk 0.96 (0.93-1.00). ${ }^{\mathrm{b}}$ Includes other non-steroidal anti-inflammatory drugs; $\geq 2$ aspirin tablets per week. ${ }^{c}$ Effect of weight reduction intervention for women already diagnosed with EC. ${ }^{\mathrm{d}}$ Dietary cadmium supplementation. ${ }^{\mathrm{e}}$ Caffeinated coffee; ${ }^{\mathrm{f}}$ De-caffeinated coffee. ${ }^{\mathrm{g}}$ Calculated as the mean difference in fasting insulin levels. ${ }^{\mathrm{h}}$ Defined as $\mathrm{BMI} \geq 30 \mathrm{~kg} / \mathrm{m}^{2} .{ }^{i}$ Vitamin A including $\beta$ carotenoids. Abbreviations: $\mathrm{RR}=$ relative risk. $\uparrow=$ increased effect. $\downarrow=$ decreased effect.

\subsection{Agaricus Mushroom}

The agaricus mushroom (Agaricus blazei Murill Kyowa, ABMK) looks a little like a chestnut mushroom and the family includes the common button mushroom used in kitchens throughout the world. This particular mushroom and its extracts has been studied in cancer patients in two clinical trials. In one study of 100 women with gynecological cancers, including those with EC, found that chemotherapy could be improved by 6 months supplementation with ABMK extract whereby there was increased anti-cancer immune natural killer cell activity [338]. Furthermore, chemotherapy side effects such as emotional instability, hair loss and loss of appetite were drastically reduced [338]. In 2011, Ohno and colleagues examined the effect of ABMK extract on 78 cancer patients in remission and 
found that a diet supplemented with 1.8-5.4 g per day also benefitted from exposure to the extract, but importantly the extract was well tolerated (in most subjects), indicating that this product is generally safe [339]. The beneficial effect of these fungal extracts is not confined to EC, since recent evidence indicates they are efficacious and well-tolerated in breast cancer [340,341] and prostate cancer patients [230], An in vitro study on three different EC cell lines indicated that extracts from three different mushrooms including the agaricus mushroom, had an inhibitory effect on cell viability and proliferation most probably through the induction of autophagy [342]. Further studies on the efficacy of agaricus extract supplementation in EC patients, both before and after diagnosis is therefore warranted.

\subsection{Resveratrol}

Resveratrol is a polyphenol molecule first identified $\mathrm{n}$ Japanese knotweed (Polygonum cuspidatum) but is now more commonly extracted from the skins of grapes. In vitro studies using several uterine models indicate that resveratrol not only inhibits cancer growth, but also initiates apoptosis [343]. In endometrial adenocarcinoma cell lines, the effects of resveratrol on cell growth and apoptosis appear to be both oestrogen-dependent and oestrogen-independent [344]. In addition, animal studies revealed that resveratrol and EGCG significantly reduced VEGF secretion by EC cells in a concentration-dependent manner, indicating resveratrol and EGCG could provide effective anti-angiogenesis therapy in patients with EC [345]. Resveratrol is found in wine, particularly red wine and is thought to also act as an antagonist at the oestrogen receptor alpha [346], thereby blocking the actions of exogenous and endogenous oestrogens. It is also an agonist at the oestrogen receptor beta, which is known to be an inhibitor of EC cell proliferation and inducer of apoptosis is other oestrogen-sensitive tissues [347]. Data from epidemiological studies indicates that consumption of three or more drinks of alcohol per day increases the risk of developing breast cancer regardless of type [348], yet some caution is advised because in vitro studies of EC cells indicated that the beneficial effect of resveratrol could be prevented if the cells undergo autophagy [349] prompting the authors to recommend that chloroquine (an autophagy inhibitor) be used to prevent the autophagy during treatment since the combination enhanced growth inhibition and cellular apoptosis.

\subsection{Curcumin}

Curcumin is chemical constituent of the spice turmeric that is used widely in South and Southeast Asian cuisine. It is also a food additive for yellow-orange coloured food in EU (E number 100) that significantly inhibits cancer cell proliferation through numerous cellular targets [350]. It also has the ability to improve insulin metabolism, and may prevent obesity-related cancers, such as EC [351]. Curcumin acts by preventing the phosphorylation of a protein (STAT-3) that acts as a transcriptional regulator intimately associated with the uncontrolled growth of cancer cells [352]. Moreover, curcumin's ability to induce apoptosis of human EC cells by the dysregulation of proto-oncogenes [353], is being exploited in a clinical trial that is due to complete in 2022 [354]. Because curcumin induces apoptosis and prevents cell cycle progression at the G2/M phase of the cell cycle in oestrogen receptor positive breast cancer cells [355] and triple negative breast cancer cells [356], it is likely a similar effect occurs in endometrial cancer cells too [357].

\subsection{Indole-3-Carbinol and Di-Indoylmethane}

Cruciferous vegetables such as cabbage, cauliflower, radishes, broccoli and Brussel sprouts all contain high concentrations of indole-3-carbinol (I3C), which in vivo is rapidly converted into diindoylmethane (DIM) [358]. DIM possesses anti-cancer properties in breast, endometrium and prostate cancers [358,359]. Because both I3C and DIM can interfere with oestrogen metabolism and signalling, they are proposed to be good candidate drugs for the treatment of hormonally-responsive cancers, and especially EC. These two compounds prevent the conversion of oestrogens into 16-hydroxyoestrogens, but promote their conversion into 2-hydroxyoestrogens. These results in two effects: (1) the stronger 
promotion of cellular proliferation by 16-hydroxyoestrogens is blunted, and (2) hormoneresponsive cell growth is reduced because 2-hydroxyoestrogens are weaker activators of the oestrogen receptor, and consequently the cells undergo less proliferation [359-364]. I3C and/or its metabolites also modulate some metabolic pathways that are critical to cancer cell survival [358] and DIM may interrupt oestrogen receptor signalling in EC cells [365]. In combination with the soy isoflavone genistein, programmed cell death is enhanced through increased TRAIL action, a protein that has cancer-cell-killing properties [366].

Rats genetically prone to developing EC, and given a diet for 660 days that was supplemented with I3C, had a lower EC rate when compared to similar rats fed a standard diet [251]. The authors showed that rats receiving the highest I3C dose, had a lower EC rate (14\%) compared to that of the standard-diet group (38\%). Ingested I3C significantly increased the 2-hydroxylation of oestradiol, thereby reducing circulating oestrogen concentrations [367]).

\subsection{Melatonin}

Melatonin, is a natural hormone produced by the pineal gland that regulates energy metabolism and sleep patterns [368]. It is produced naturally through darkness and through effective sleep patterns. Melatonin may also help prevent the development of tumours that are responsive to sex steroid hormones, such as those of the prostate, breast, and most gynaecological cancers (EC, cervical and ovarian cancer) $[369,370]$ and breast cancer [371]. Patients with non-small cell lung cancer benefit from additional melatonin therapy because it also improves the effectiveness of chemotherapy [369,372-375]. Several studies have shown that melatonin has many anti-cancer activities, such as directly promoting cancer cell death and independently promoting immune responses against some tumour cells [376], but not all [377,378]. Melatonin release into the blood is highest in the early hours of the morning and as such, a lifestyle that includes regular sleep patterns is important because of its regulation of energy balance and metabolism [379]. It has three major effects with respect to EC: (1) it acts as a p450 aromatase inhibitor and so stops the production of oestrogen from androgens [380], (2) it destroys free radicals, which can cause DNA, lipid and protein damage $[381,382]$ and (3) it enhances the anti-tumour activity of vitamin D [383], which we have already seen enhances the anti-EC effects of progestogens, by increasing the expression of the progesterone receptor in endometrial cells.

In conclusion, the role of plant derived materials and hormones in the incidence of EC is stronger than that for vitamins and minerals. Some organisations, such as the IARC [41], the World Cancer Research Fund [4] and the World Health Organization [40] support the notion that some plant derivatives, especially coffee and tea, and other substances high in anti-oxidative power are beneficial and prevent the development of EC.

\section{Clinical Trials and Studies}

It is been known for many years that a diet rich in mono-saturated and trans-fats are detrimental to the development of cancers and that diets rich in plant foods are beneficial [384], yet there are very few clinical trials that identify 'good' foods that benefit patients already diagnosed with EC, only those that indicate what should be avoided.

The biggest study designed to investigate the relationship between nutrition and cancer is the European Prospective Investigation into Cancer and Nutrition (EPIC) study, which is an ongoing multi-centre prospective cohort study [385]. It is well suited to study the influence of diet on cancer risk because of the large variation in dietary patterns across the 10 collaborating Western European countries [386]. Cust and colleagues in an interim report gathered from the EPIC study examined the effect of carbohydrate on the development of EC, where they concluded that there is no association of overall glycaemic index, total starch, or total fibre intake with the risk of developing EC [387], but that there is a possible modest positive association of total carbohydrates, total dietary glycaemic load, and total sugars with risk of developing EC, particularly amongst women who have never used hormone replacement therapy [387]. They also demonstrated that glucose, plasma 
lipid and lipoproteins in the context of metabolic syndrome were risk factors in the same cohort [97].

Aarestrup and colleagues in 2012 conducted a study investigating the association of whole grains and dietary fibre with the incidence of EC in Danish women and showed there to be no clear associations between intake of whole grains or dietary fibre and the incidence of EC [388]. In addition, a similar study conducted in Western New York by McCann and colleagues in 2000, discovered a reduced risk of developing EC was associated with a diet rich in plant food [222]. A case-control study in Mexico suggested dietary vitamin $\mathrm{D}$ and calcium might play an important role in reducing the development of EC but no association between the consumption of animal or vegetable proteins and fats with EC was found [256].

These studies performed in China, the United States of America, Canada, Mexico and Denmark provide limited and inconclusive evidence regarding the association of these modifiable factors with the risk of developing EC. To our knowledge, no study has yet been performed to determine the association of dietary pattern and lifestyle habit with the risk of developing EC among women in the UK, although there is an on-going study (ISRCTN1538157) that is examining the effect of general weight loss through a 12 month weight loss programme on the incidence of endometrial cancer (and breast cancer); the results are awaiting trial completion in 2023. In women previously diagnosed with endometrial cancer, a pilot trial (NCT02433080) on the general effect of diet and exercise on quality of life by questionnaire demonstrated a significantly improved quality of life (difference of 8.9) at 24 weeks, but suffered from small sample numbers (29 in the intervention group and 31 in the control group), with incomplete follow-up [389]. In the USA, a similar study of 196 obese endometrial cancer survivors demonstrated that a combination of weight loss and the use of technology in the form a text-based app provided sufficient motivation for a $4.4 \mathrm{~kg}$ weight loss that increased the patients' quality of life [390], suggesting that encouragement of weight loss in endometrial cancer survivors, either by dietary changes [391], increased physical activity [392] or enhancement of usual care can be beneficial for such patients [390]. Such interventions in EC survivors may even prevent disease recurrence, although definitive conclusions or studies supporting such a conclusion are lacking. Other studies in EC survivors have either been withdrawn (NCT03042897), are on-going (NCT02465541; NCT01697566; NCT04534309) or have completed (NCT00420979; NCT00587886; NCT01610375; NCT04000880) without clear conclusions that exercise or dietary changes can improve a patient's quality of life [393,394] or are designed to test existing interventions, such as the use of metformin as a chemo-preventative agent (NCT01697566; NCT02431676). Therefore, we suggest that further studies need to be designed to explore the association between the lifestyle habits and dietary intake among women with the risk of developing EC here in the UK, especially as regional differences in EC incidence, prevalence and mortality appear to be changing around the world.

In an on-going phase II clinical study (NCT03192059), curcumin is under evaluation as an adjuvant (food supplement) in patients with advanced and/or refractory cervical cancer, endometrial carcinoma or uterine sarcoma who are simultaneously being treated with an immunomodulatory cocktail (vitamin D, aspirin, cyclophosphamide and lansoprazole), followed by pembrolizumab, combined with radiation [354]. No preliminary data are available yet, but this cocktail is expected to yield positive results.

\section{Current Research Models and Future Research Directions}

In preparing this manuscript it has become increasingly obvious that research into the effects of nutrition, diet and lifestyle on the prevention of cancer and general health is difficult [395]. Although we have summarised here the relatively few better-established links between nutrition, lifestyle changes and the prevention of several cancers, what the most important risk factors with respect to EC appear to be obesity and a sedentary lifestyle $[35,90]$. Which diets or lifestyle corrections can be made or which specific food 
components or broader dietary patterns, such as the so called plant-based diets, will be important in the future remains unclear $[37,180,193]$.

To move forward, a new generation of studies need to be created to improve estimates of long-term exposure with, for example, repeated dietary records, which are now feasible using web-based questionnaires [396,397] even though these are rarely used in place of the food frequency questionnaires that suffer from recall bias [398,399]. Cancer-specific biomarkers of dietary intake and nutritional status should be used more extensively, and new cancer tissue biomarkers might be found through proteomics and metabolomics studies, for example, but these too are problematic in that anything found will still need to be validated and interpreted in the light of possible confounding and reverse causations. For some exposures, both for intake and nutritional status, Mendelian randomisation has been suggested to be able to clarify causality [400]. Of course, when something has been identified to be linked to the reduction of EC risk or improves prognosis, randomised trials will be needed to test specific hypotheses. It will also be important to attempt to coordinate systematic analyses of all the data available worldwide, in order to reduce the risk of population bias [401]. For public health and healthcare policy makers, the top priority should be tackling the known major diet-related risk factors for EC, particularly obesity and alcohol [200].

In all of these cases, the best model for study is the patient at highest risk of developing EC and that is the adult woman. Although other models, such as human and animal cell lines, rodent, primate and other animal models (including xenobiotic implants) are useful in defining the molecular mechanisms and physiology of interactions between food, nutrients and EC risk, they are not as useful for studying interactions between lifestyle interventions (such as regular exercise, weight loss programs or getting a good night's sleep), even if the recovering EC patient does not adhere to advice [402]. There is still a long way to go.

\section{Conclusions}

Although there is substantial evidence that moderate levels of physical activity, bearing children, delayed menopause and eating foods that are rich in lutein (fruits and vegetables) can protect against obesity and the associated conditions of hyperinsulinaemia and metabolic syndrome and the risk of developing type 2 diabetes mellitus [323] and that alcohol consumption may increase, and coffee and tea consumption may reduce, the risk of EC [307,326,403], these interventions have not yet filtered through to the patients at risk. More evidence is thus required for meta-analysis of the individual factors that prevent EC incidence [4] and that will come from further study. A key conclusion therefore is that although some clinical trials support dietary and lifestyle alterations, there is room for more to be conducted.

Recommendations for women wishing to prevent EC and for those wishing to prevent recurrence, are difficult and although the global incidence of EC is increasing, prevention can be achieved if the patient modifies her diet and lifestyle. Women at risk should; (1) lose weight (if overweight or obese (as many EC patients are)) since doing so can reverse their risk of developing hyperinsulinaemia; (2) eat a diet rich in protein but with a low GI that contains wholegrains, vegetables, fruits and legumes, whilst reducing their consumption of foods that are high in fat, sugar or starch, red or processed meats. They should also (3) restrict their alcohol consumption, but drink 2-3 cups of filter coffee per day instead, because this aids the 'slimming' process and may reduce the risk of recurrent disease, or drink 1-2 cups of green tea, and although the evidence is limited, (4) make sure that she spends at least 20 min every day doing some form of moderate to intense exercise, since this aids the 'slimming process' and reduces the risk of entering a chronic inflammatory state (a clear risk factor for all forms of cancer), but especially gynaecological cancers such as EC. 
Funding: This research received no external funding.

Acknowledgments: The authors acknowledge the assistance of Stephen Molloy at the Liverpool Women's Hospital Library and Clare Daniel, West Cumberland Hospital, in performing the extensive literature searches. Thank you.

Conflicts of Interest: The authors declare no conflict of interest.

\section{References}

1. Wu, S.; Powers, S.E.; Zhu, W.; Hannun, Y.A. Substantial contribution of extrinsic risk factors to cancer development. Nat. Cell Biol. 2015, 529, 43-47. [CrossRef] [PubMed]

2. Trovato, G.M. Behavior, nutrition and lifestyle in a comprehensive health and disease paradigm: Skills and knowledge for a predictive, preventive and personalized medicine. EPMA J. 2012, 3, 1-8. [CrossRef] [PubMed]

3. Moreno-Smith, M.; Lutgendorf, S.K.; Sood, A.K. Impact of stress on cancer metastasis. Futur. Oncol. 2010, 6, 1863-1881. [CrossRef] [PubMed]

4. World Cancer Research Fund. Diet, Nutrition, Physical Activity and Endometrial Cancer. Available online: https://www.wcrf. org/dietandcancer (accessed on 23 January 2021).

5. Kruk, J. Self-reported psychological stress and the risk of breast cancer: A case-control study. Stress 2011, 15, 162-171. [CrossRef]

6. Mouchacca, J.; Abbott, G.R.; Ball, K. Associations between psychological stress, eating, physical activity, sedentary behaviours and body weight among women: A longitudinal study. BMC Public Health 2013, 13, 828. [CrossRef]

7. Nielsen, N.R.; Strandberg-Larsen, K.; Grønbæk, M.; Kristensen, T.S.; Schnohr, P.; Zhang, Z.-F. Self-reported stress and risk of endometrial cancer: A prospective cohort study. Psychosom. Med. 2007, 69, 383-389. [CrossRef]

8. Cho, H.J.; Kwon, G.T.; Park, H.; Song, H.; Lee, K.W.; Kim, J.-I.; Park, J.H.Y. A high-fat diet containing lard accelerates prostate cancer progression and reduces survival rate in mice: Possible contribution of adipose tissue-derived cytokines. Nutrition 2015, 7, 2539-2561. [CrossRef]

9. Zhu, Y.; Aupperlee, M.D.; Zhao, Y.; Tan, Y.S.; Kirk, E.L.; Sun, X.; Troester, M.A.; Schwartz, R.C.; Haslam, S.Z. Pubertal and adult windows of susceptibility to a high animal fat diet in Trp53-null mammary tumorigenesis. Oncotarget 2016, 7, 83409-83423. [CrossRef]

10. Lee, J. The obesity pandemic and the search for solutions. J. Med. Food 2020, 23, 205. [CrossRef]

11. Zhu, Y.; Shen, J.; Gao, L.; Feng, Y. Estrogen promotes fat mass and obesity-associated protein nuclear localization and enhances endometrial cancer cell proliferation via the mTOR signaling pathway. Oncol. Rep. 2016, 35, 2391-2397. [CrossRef]

12. Allen, N.E.; Key, T.J.; Dossus, L.; Rinaldi, S.; Cust, A.; Lukanova, A.; Peeters, P.H.; Onland-Moret, N.C.; Lahmann, P.H.; Berrino, F.; et al. Endogenous sex hormones and endometrial cancer risk in women in the European Prospective Investigation into Cancer and Nutrition (EPIC). Endocr. Relat. Cancer 2008, 15, 485-497. [CrossRef]

13. De Gonzalo-Calvo, D.; López-Vilaró, L.; Nasarre, L.; Perez-Olabarria, M.; Vázquez, T.; Escuin, D.; Badimon, L.; Barnadas, A.; Lerma, E.; Llorente-Cortés, V. Intratumor cholesteryl ester accumulation is associated with human breast cancer proliferation and aggressive potential: A molecular and clinicopathological study. BMC Cancer 2015, 15, 1-14. [CrossRef]

14. Pyragius, C.E.; Fuller, M.; Ricciardelli, C.; Oehler, M.K. Aberrant lipid metabolism: An emerging diagnostic and therapeutic target in ovarian cancer. Int. J. Mol. Sci. 2013, 14, 7742-7756. [CrossRef]

15. Bosetti, C.; Bravi, F.; Turati, F.; Edefonti, V.; Polesel, J.; Decarli, A.; Negri, E.; Talamini, R.; Franceschi, S.; La Vecchia, C.; et al. Nutrient-based dietary patterns and pancreatic cancer risk. Ann. Epidemiol. 2013, 23, 124-128. [CrossRef]

16. Choi, W.J.; Kim, J. Dietary factors and the risk of thyroid cancer: A review. Clin. Nutr. Res. 2014, 3, 75-88. [CrossRef]

17. Godos, J.; Bella, F.; Torrisi, A.; Sciacca, S.; Galvano, F.; Grosso, G. Dietary patterns and risk of colorectal adenoma: A systematic review and meta-analysis of observational studies. J. Hum. Nutr. Diet. 2016, 29, 757-767. [CrossRef]

18. Magalhães, B.; Peleteiro, B.; Lunet, N. Dietary patterns and colorectal cancer: Systemic review and meta-analysis. Eur. J. Cancer Prev. 2012, 21, 15-23. [CrossRef]

19. Markaki, I.; Linos, D.; Linos, A. The influence of dietary patterns on the development of thyroid cancer. Eur. J. Cancer 2003, 39, 1912-1919. [CrossRef]

20. Pericleous, M.; Rossi, R.E.; Mandair, D.; Whyand, T.; Caplin, M.E. Nutrition and pancreatic cancer. Anticancer Res. 2014, 34, 9-21. [PubMed]

21. Rossi, R.E.; Pericleous, M.; Mandair, D.; Whyand, T.; Caplin, M.E. The role of dietary factors in prevention and progression of breast cancer. Anticancer Res. 2014, 34, 6861-6875. [PubMed]

22. Malik, T.Y.; Chishti, U.; Aziz, A.B.; Sheikh, I. Comparison of risk factors and survival of Type 1 and Type II endometrial cancers. Pak. J. Med. Sci. 1969, 32, 886-890. [CrossRef] [PubMed]

23. Cancer Research UK. Uterine Cancer Statistics. 2014. Available online: https://www.cancerresearchuk.org/health-professional/ cancer-statistics/statistics-by-cancer-type/uterine-cancer (accessed on 25 August 2020).

24. Amant, F.; Moerman, P.; Neven, P.; Timmerman, D.; Van Limbergen, E.; Vergote, I. Endometrial cancer. Lancet 2005, 366, 491-505. [CrossRef]

25. Carlson, M.J.; Thiel, K.W.; Yang, S.; Leslie, K.K. Catch it before it kills: Progesterone, obesity, and the prevention of endometrial cancer. Discov. Med. 2012, 14, 215-222. [PubMed] 
26. Lee, W.-L.; Lee, F.-K.; Su, W.-H.; Tsui, K.-H.; Kuo, C.-D.; Hsieh, S.-L.E.; Wang, P.-H. Hormone therapy for younger patients with endometrial cancer. Taiwan. J. Obstet. Gynecol. 2012, 51, 495-505. [CrossRef] [PubMed]

27. Beral, V.; Bull, D.; Reeves, G.; Million Women Study Collaborators. Endometrial cancer and hormone-replacement therapy in the Million Women Study. Lancet 2005, 365, 1543-1551. [CrossRef]

28. Berstein, L.; Tsyrlina, E.; Poroshina, T.; Bychkova, N.; Kalinina, N.; Gamajunova, V.; Vasilyev, D.; Kovalenko, I. Switching (overtargeting) of estrogen effects and its potential role in hormonal carcinogenesis. Neoplasma 2002, 49, 21-25. [PubMed]

29. Woodruff, J.; Pickar, J.H. Incidence of endometrial hyperplasia in postmenopausal women taking conjugated estrogens (Premarin) with medroxyprogesterone acetate or conjugated estrogens alone. Am. J. Obstet. Gynecol. 1994, 170, 1213-1223. [CrossRef]

30. Fader, A.N.; Arriba, L.N.; Frasure, H.E.; Von Gruenigen, V.E. Endometrial cancer and obesity: Epidemiology, biomarkers, prevention and survivorship. Gynecol. Oncol. 2009, 114, 121-127. [CrossRef]

31. Friberg, E.; Wallin, A.; Wolk, A. Sucrose, high-sugar foods, and risk of endometrial cancer-A population-based cohort study. Cancer Epidemiol. Biomark. Prev. 2011, 20, 1831-1837. [CrossRef]

32. Goodman, M.T.; Hankin, J.H.; Wilkens, L.R.; Lyu, L.C.; McDuffie, K.; Liu, L.Q.; Kolonel, L.N. Diet, body size, physical activity, and the risk of endometrial cancer. Cancer Res. 1997, 57, 5077-5085. [PubMed]

33. Hu, F.B. Overweight and obesity in women: Health risks and consequences. J. Women's Health 2003, 12, 163-172. [CrossRef]

34. McTiernan, A.; Irwin, M.; Vongruenigen, V. Weight, physical activity, diet, and prognosis in breast and gynecologic cancers. J. Clin. Oncol. 2010, 28, 4074-4080. [CrossRef]

35. Nakamura, K.; Hongo, A.; Kodama, J.; Hiramatsu, Y. Fat accumulation in adipose tissues as a risk factor for the development of endometrial cancer. Oncol. Rep. 2011, 26, 65-71. [CrossRef]

36. Biel, R.K.; Csizmadi, I.; Cook, L.S.; Courneya, K.S.; Magliocco, A.M.; Friedenreich, C.M. Risk of endometrial cancer in relation to individual nutrients from diet and supplements. Public Health Nutr. 2011, 14, 1948-1960. [CrossRef]

37. Biel, R.K.; Friedenreich, C.M.; Csizmadi, I.; Robson, P.J.; McLaren, L.; Faris, P.; Courneya, K.S.; Magliocco, A.M.; Cook, L.S. Case-Control study of dietary patterns and endometrial cancer risk. Nutr. Cancer 2011, 63, 673-686. [CrossRef]

38. Hecht, J.L.; Mutter, G.L. Molecular and pathologic aspects of endometrial carcinogenesis. J. Clin. Oncol. 2006, $24,4783-4791$. [CrossRef]

39. Tashiro, H.; Blazes, M.S.; Wu, R.; Cho, K.R.; Bose, S.; Wang, S.I.; Li, J.; Parsons, R.; Ellenson, L.H. Mutations in PTEN are frequent in endometrial carcinoma but rare in other common gynecological malignancies. Cancer Res. 1997, 57, 3935-3940.

40. World Health Organization. GLOBOCAN-CANCER TODAY. Available online: https://gco.iarc.fr/today/data/factsheets/ cancers /24-Corpus-uteri-fact-sheet.pdf (accessed on 19 April 2021).

41. World Health Organization. International Agency for Research on Cancer Today. Available online: https://www.iarc.who.int/ infographics/globocan-2018-latest-global-cancer-data / (accessed on 19 April 2021).

42. Zhang, S.; Gong, T.-T.; Liu, F.-H.; Jiang, Y.-T.; Sun, H.; Ma, X.-X.; Zhao, Y.-H.; Wu, Q.-J. Global, regional, and national burden of endometrial cancer, 1990-2017: Results from the Global Burden of Disease Study, 2017. Front. Oncol. 2019, 9. [CrossRef]

43. Adlercreutz, H.; Mazur, W. Phyto-oestrogens and western diseases. Ann. Med. 1997, 29, 95-120. [CrossRef]

44. Allen, N.E.; Key, T.J. The effects of diet on circulating sex hormone levels in men. Nutr. Res. Rev. 2000, 13, 159-184. [CrossRef]

45. Lahmann, P.H.; Hughes, M.C.; Ibiebele, T.I.; Mulligan, A.A.; Kuhnle, G.G.C.; Webb, P.M. Estimated intake of dietary phytooestrogens in Australian women and evaluation of correlates of phyto-oestrogen intake. J. Nutr. Sci. 2012, 1, 11. [CrossRef]

46. Bogess, J.F.; Kilgore, J.E.; Tran, A.-Q. Uterine cancer. In Abeloff's Clinical Oncology, 6th ed.; Niederhuber, J.E., Armitage, J.O., Kastan, M.B., Doroshow, J.H., Tepper, J.E., Eds.; Elsevier, Inc.: Philadelphia, PA, USA, 2020; pp. 1508-1524.

47. White, M. Food access and obesity. Obes. Rev. 2007, 8, 99-107. [CrossRef]

48. Morris, M.J.; Beilharz, J.E.; Maniam, J.; Reichelt, A.C.; Westbrook, R.F. Why is obesity such a problem in the 21st century? The intersection of palatable food, cues and reward pathways, stress, and cognition. Neurosci. Biobehav. Rev. 2015, 58, 36-45. [CrossRef]

49. Agarwal, V.R.; Ashanullah, C.I.; Simpson, E.R.; Bulun, S.E. Alternatively spliced transcripts of the aromatase cytochrome P450 (CYP19) gene in adipose tissue of women. J. Clin. Endocrinol. Metab. 1997, 82, 70-74. [CrossRef] [PubMed]

50. Bulun, S.E.; Simpson, E.R. Competitive reverse transcription-polymerase chain reaction analysis indicates that levels of aromatase cytochrome P450 transcripts in adipose tissue of buttocks, thighs, and abdomen of women increase with advancing age. J. Clin. Endocrinol. Metab. 1994, 78, 428-432. [CrossRef] [PubMed]

51. Hemsell, D.L.; Grodin, J.M.; Brenner, P.F.; Siiteri, P.K.; Macdonald, P.C. Plasma precursors of estrogen. II. Correlation of the extent of conversion of plasma androstenedione to estrone with age. J. Clin. Endocrinol. Metab. 1974, 38, 476-479. [CrossRef] [PubMed]

52. Lukanova, A.; Lundin, E.; Micheli, A.; Arslan, A.; Ferrari, P.; Rinaldi, S.; Krogh, V.; Lenner, P.; Shore, R.E.; Biessy, C.; et al. Circulating levels of sex steroid hormones and risk of endometrial cancer in postmenopausal women. Int. J. Cancer 2003, 108, 425-432. [CrossRef] [PubMed]

53. Nelson, L.R.; Bulun, S.E. Estrogen production and action. J. Am. Acad. Dermatol. 2001, 45, 116-124. [CrossRef] [PubMed]

54. Kaaks, R.; Lukanova, A.; Kurzer, M.S. Obesity, endogenous hormones, and endometrial cancer risk: A synthetic review. Cancer Epidemiol. Biomark. Prev. 2002, 11, PMID:12496040. [PubMed]

55. Reeves, G.K.; Pirie, K.; Beral, V.; Green, J.; Spencer, E.; Bull, D. Cancer incidence and mortality in relation to body mass index in the Million Women Study: Cohort study. BMJ 2007, 335, 1134. [CrossRef] 
56. Schmandt, R.E.; Iglesias, D.A.; Na Co, N.; Lu, K.H. Understanding obesity and endometrial cancer risk: Opportunities for prevention. Am. J. Obstet. Gynecol. 2011, 205, 518-525. [CrossRef]

57. Tempfer, C.; Hilal, Z.; Kern, P.; Juhasz-Boess, I.; Rezniczek, G. Menopausal hormone therapy and risk of endometrial cancer: A systematic review. Cancers 2020, 12, 2195. [CrossRef]

58. Crosbie, E.J.; Zwahlen, M.; Kitchener, H.C.; Egger, M.; Renehan, A.G. Body mass index, hormone replacement therapy, and endometrial cancer risk: A meta-analysis. Cancer Epidemiol. Biomark. Prev. 2010, 19, 3119-3130. [CrossRef]

59. Chang, S.-C.; Lacey, J.V.; Brinton, L.A.; Hartge, P.; Adams, K.; Mouw, T.; Carroll, L.; Hollenbeck, A.; Schatzkin, A.; Leitzmann, M.F. Lifetime weight historyand endometrialcancerriskby type of menopausal hormone use in the NIH-AARP diet and health study. Cancer Epidemiol. Biomark. Prev. 2007, 16, 723-730. [CrossRef]

60. Cancer Research UK. Cancer Research Statistics, Cancer Incidence and Mortality in the UK. Available online: http://www. cancerresearchuk.org/cancer-info/cancerstats/types/uterus/ (accessed on 2 September 2020).

61. Ayakannu, T.; Taylor, A.H.; Konje, J.C. Cannabinoid receptor expression in estrogen-dependent and estrogen-independent endometrial cancer. J. Recept. Signal Transduct. 2018, 38, 385-392. [CrossRef]

62. Urick, M.E.; Bell, D.W. Clinical actionability of molecular targets in endometrial cancer. Nat. Rev. Cancer 2019, 19, 510-521. [CrossRef]

63. Ritterhouse, L.L.; Howitt, B.E. Molecular pathology. Predict. Progn. Diagn. Markers Uterine Tumors 2016, 9, 405-426. [CrossRef]

64. Long, B.; Lilyquist, J.; Weaver, A.; Hu, C.; Gnanaolivu, R.; Lee, K.Y.; Hart, S.N.; Polley, E.C.; Bakkum-Gamez, J.N.; Couch, F.J.; et al. Cancer susceptibility gene mutations in type I and II endometrial cancer. Gynecol. Oncol. 2019, 152, 20-25. [CrossRef]

65. Lax, S.F. Molecular genetic pathways in various types of endometrial carcinoma: From a phenotypical to a molecular-based classification. Virchows Arch. 2004, 444, 213-223. [CrossRef]

66. Lax, S.F.; Kendall, B.; Tashiro, H.; Slebos, R.J.; Hedrick, L. The frequency of p53, K-ras mutations, and microsatellite instability differs in uterine endometrioid and serous carcinoma: Evidence of distinct molecular genetic pathways. Cancer 2000, 88, PMID:10679651. [CrossRef] [PubMed]

67. Fadare, O.; Zheng, W. Insights into endometrial serous carcinogenesis and progression. Int. J. Clin. Exp. Pathol. 2009, 2, 411-432. [PubMed]

68. Okuda, T.; Sekizawa, A.; Purwosunu, Y.; Nagatsuka, M.; Morioka, M.; Hayashi, M.; Okai, T. Genetics of endometrial cancers. Obstet. Gynecol. Int. 2010, 2010, 1-8. [CrossRef]

69. López-Reig, R.; Fernández-Serra, A.; Romero, I.; Zorrero, C.; Illueca, C.; García-Casado, Z.; Poveda, A.; López-Guerrero, J.A. Prognostic classification of endometrial cancer using a molecular approach based on a twelve-gene NGS panel. Sci. Rep. 2019, 9, 1-9. [CrossRef]

70. Kandoth, C.; Schultz, N.; Cherniack, A.D.; Akbani, R.; Liu, Y.; Shen, H.; Robertson, A.G.; Pashtan, I.; Shen, R.; et al.; The Cancer Genome Atlas Research Network. Integrated genomic characterization of endometrial carcinoma. Nat. Cell Biol. 2013, 497, 67-73. [CrossRef]

71. Morice, P.; Leary, A.; Creutzberg, C.; Abu-Rustum, N.; Darai, E. Endometrial cancer. Lancet 2016, 387, 1094-1108. [CrossRef]

72. Oberndorfer, F.; Moling, S.; Hagelkruys, L.; Grimm, C.; Polterauer, S.; Sturdza, A.; Aust, S.; Reinthaller, A.; Müllauer, L.; Schwameis, R. Risk reclassification of patients with endometrial cancer based on tumor molecular profiling: First real world data. J. Pers. Med. 2021, 11, 48. [CrossRef]

73. Sugiyama, Y.; Gotoh, O.; Fukui, N.; Tanaka, N.; Hasumi, K.; Takazawa, Y.; Noda, T.; Mori, S. Two distinct tumorigenic processes in endometrial endometrioid adenocarcinoma. Am. J. Pathol. 2020, 190, 234-251. [CrossRef]

74. Bokhman, J.V. Two pathogenetic types of endometrial carcinoma. Gynecol. Oncol. 1983, 15, 10-17. [CrossRef]

75. Weigelt, B.; Banerjee, S. Molecular targets and targeted therapeutics in endometrial cancer. Curr. Opin. Oncol. 2012, 24, 554-563. [CrossRef] [PubMed]

76. Salvesen, H.B.; Haldorsen, I.S.; Trovik, J. Markers for individualised therapy in endometrial carcinoma. Lancet Oncol. 2012, 13, 353-361. [CrossRef]

77. Matias-Guiu, X.; Prat, J. Molecular pathology of endometrial carcinoma. Histopathology 2012, 62, 111-123. [CrossRef]

78. Dedes, K.J.; Wetterskog, D.; Ashworth, A.; Kaye, S.B.; Reis-Filho, J.S. Emerging therapeutic targets in endometrial cancer. Nat. Rev. Clin. Oncol. 2011, 8, 261-271. [CrossRef]

79. Zhao, S.; Choi, M.; Overton, J.D.; Bellone, S.; Roque, D.M.; Cocco, E.; Guzzo, F.; English, D.P.; Varughese, J.; Gasparrini, S.; et al. Landscape of somatic single-nucleotide and copy-number mutations in uterine serous carcinoma. Proc. Natl. Acad. Sci. USA 2013, 110, 2916-2921. [CrossRef]

80. Urick, M.E.; Rudd, M.L.; Godwin, A.K.; Sgroi, D.C.; Merino, M.J.; Bell, D.W. PIK3R1 (p85 $\alpha$ ) is somatically mutated at high frequency in primary endometrial cancer. Cancer Res. 2011, 71, 4061-4067. [CrossRef]

81. McConechy, M.K.; Ding, J.; Cheang, M.C.; Wiegand, K.C.; Senz, J.; Tone, A.A.; Yang, W.; Prentice, L.M.; Tse, K.; Zeng, T.; et al. Use of mutation profiles to refine the classification of endometrial carcinomas. J. Pathol. 2012, 228, 20-30. [CrossRef]

82. Le Gallo, M.; N.I.S.C. Program; O’Hara, A.J.; Rudd, M.L.; Urick, M.E.; Hansen, N.F.; O’Neil, N.J.; Price, J.C.; Zhang, S.; England, B.M.; et al. Exome sequencing of serous endometrial tumors identifies recurrent somatic mutations in chromatin-remodeling and ubiquitin ligase complex genes. Nat. Genet. 2012, 44, 1310-1315. [CrossRef]

83. Kuhn, E.; Wu, R.-C.; Guan, B.; Wu, G.; Zhang, J.; Wang, Y.; Song, L.; Yuan, X.; Wei, L.; Roden, R.B.; et al. Identification of molecular pathway aberrations in uterine serous carcinoma by genome-wide analyses. J. Natl. Cancer Inst. 2012, 104, 1503-1513. [CrossRef] 
84. Constantine, G.D.; Kessler, G.; Graham, S.; Goldstein, S.R. Increased incidence of endometrial cancer following the Women's Health Initiative: An assessment of risk factors. J. Women's Health 2019, 28, 237-243. [CrossRef]

85. Key, T.J.; Pike, M.C. The dose-effect relationship between 'unopposed' oestrogens and endometrial mitotic rate: Its central role in explaining and predicting endometrial cancer risk. Br. J. Cancer 1988, 57, 205-212. [CrossRef]

86. Barakat, R.R. Benign and hyperplastic endometrial changes associated with tamoxifen use. Oncology 1997, 11. [PubMed]

87. Dai, Y.; Lin, X.; Xu, W.; Lin, X.; Huang, Q.; Shi, L.; Pan, Y.; Zhang, Y.; Zhu, Y.; Li, C.; et al. MiR-210-3p protects endometriotic cells from oxidative stress-induced cell cycle arrest by targeting BARD1. Cell Death Dis. 2019, 10, 1-15. [CrossRef]

88. Pfeifer, G.P.; Denissenko, M.F.; Olivier, M.; Tretyakova, N.; Hecht, S.S.; Hainaut, P. Tobacco smoke carcinogens, DNA damage and p53 mutations in smoking-associated cancers. Oncogene 2002, 21, 7435-7451. [CrossRef]

89. Jochem, C.; Wallmann-Sperlich, B.; Leitzmann, M.F. The influence of sedentary behavior on cancer risk: Epidemiologic evidence and potential molecular mechanisms. Curr. Nutr. Rep. 2019, 8, 167-174. [CrossRef]

90. Moore, S.C.; Gierach, G.L.; Schatzkin, A.; Matthews, C.E. Physical activity, sedentary behaviours, and the prevention of endometrial cancer. Br. J. Cancer 2010, 103, 933-938. [CrossRef]

91. Blümel, J.E.; Chedraui, P.; Aedo, S.; Fica, J.; Mezones-Holguín, E.; Barón, G.; Bencosme, A.; Benítez, Z.; Bravo, L.M.; Calle, A.; et al. Obesity and its relation to depressive symptoms and sedentary lifestyle in middle-aged women. Maturitas 2015, 80, 100-105. [CrossRef] [PubMed]

92. Memon, A.; Paudyal, P. Epidemiology of endometrial cancer. In Endometrial Cancer: Current Epidemiology, Detection and Management; Farghaly, S.A., Ed.; Nova Biomedical: New York, NY, USA, 2015; pp. 1-14.

93. Shang, Y. Molecular mechanisms of oestrogen and SERMs in endometrial carcinogenesis. Nat. Rev. Cancer 2006, 6, 360-368. [CrossRef]

94. Friedenreich, C.M.; Neilson, H.K.; Woolcott, C.G.; Wang, Q.; Yasui, Y.; Brant, R.F.; Stanczyk, F.Z.; Campbell, K.L.; Courneya, K.S Mediators and moderators of the effects of a year-long exercise intervention on endogenous sex hormones in postmenopausal women. Cancer Causes Control. 2011, 22, 1365-1373. [CrossRef]

95. Healy, G.N.; Wijndaele, K.; Dunstan, D.W.; Shaw, J.E.; Salmon, J.; Zimmet, P.Z.; Owen, N. Objectively measured sedentary time, physical activity, and metabolic risk: The Australian Diabetes, Obesity and Lifestyle Study (AusDiab). Diabetes Care 2007, 31, 369-371. [CrossRef]

96. Helmerhorst, H.J.F.; Wijndaele, K.; Brage, S.; Wareham, N.J.; Ekelund, U. Objectively measured sedentary time may predict insulin resistance independent of moderate- and vigorous-intensity physical activity. Diabetes 2009, 58, 1776-1779. [CrossRef]

97. Cust, A.E.; Kaaks, R.; Friedenreich, C.; Bonnet, F.; Laville, M.; Tjønneland, A.; Olsen, A.; Overvad, K.; Jakobsen, M.U.; Chajès, V.; et al. Metabolic syndrome, plasma lipid, lipoprotein and glucose levels, and endometrial cancer risk in the European Prospective Investigation into Cancer and Nutrition (EPIC). Endocr. Relat. Cancer 2007, 14, 755-767. [CrossRef]

98. Friedenreich, C.M.; Biel, R.K.; Lau, D.C.; Csizmadi, I.; Courneya, K.S.; Magliocco, A.M.; Yasui, Y.; Cook, L.S. Case-control study of the metabolic syndrome and metabolic risk factors for endometrial cancer. Cancer Epidemiol. Biomark. Prev. 2011, 20, 2384-2395. [CrossRef] [PubMed]

99. Arthur, R.S.; Kabat, G.C.; Kim, M.Y.; Wild, R.A.; Shadyab, A.H.; Wactawski-Wende, J.; Ho, G.Y.F.; Reeves, K.W.; Kuller, L.H.; Luo, J.; et al. Metabolic syndrome and risk of endometrial cancer in postmenopausal women: A prospective study. Cancer Causes Control. 2019, 30, 355-363. [CrossRef] [PubMed]

100. Friberg, E.; Mantzoros, C.S.; Wolk, A. Physical activity and risk of endometrial cancer: A population-based prospective cohort study. Cancer Epidemiol. Biomark. Prev. 2006, 15, 2136-2140. [CrossRef] [PubMed]

101. Owen, N.; Bauman, A.; Brown, W. Too much sitting: A novel and important predictor of chronic disease risk? Br. J. Sports Med. 2008, 43, 81-83. [CrossRef]

102. Blanck, H.M.; McCullough, M.L.; Patel, A.V.; Gillespie, C.; Calle, E.E.; Cokkinides, V.E.; Galuska, D.A.; Khan, L.K.; Serdula, M.K. Sedentary behavior, recreational physical activity, and 7-Year weight gain among postmenopausal U.S. women. Obesity 2007, 15, 1578-1588. [CrossRef]

103. Westerterp, K.R. Physical activity and physical activity induced energy expenditure in humans: Measurement, determinants, and effects. Front. Physiol. 2013, 4, 90. [CrossRef]

104. McTiernan, A. Mechanisms linking physical activity with cancer. Nat. Rev. Cancer 2008, 8, 205-211. [CrossRef]

105. Zhao, F.; Wang, X.; Wang, Y.; Zhang, J.; Lai, R.; Zhang, B.; Zhou, X. The function of uterine UDP-glucuronosyltransferase 1A8 (UGT1A8) and UDP-glucuronosyltransferase 2B7 (UGT2B7) is involved in endometrial cancer based on estrogen metabolism regulation. Hormones 2020, 19, 403-412. [CrossRef]

106. Behar, J. Physiology and pathophysiology of the biliary tract: The gallbladder and sphincter of Oddi-A review. ISRN Physiol. 2013, 2013, 1-15. [CrossRef]

107. Boyer, J.L. Bile formation and secretion. Compr. Psysiol. 2013, 3, 1035-1078. [CrossRef]

108. Gibson, D.A.; Collins, F.; Cousins, F.L.; Zufiaurre, A.E.; Saunders, P.T.K. The impact of 27-hydroxycholesterol on endometrial cancer proliferation. Endocr. Relat. Cancer 2018, 25, 381-391. [CrossRef]

109. Gong, T.-T.; Li, D.; Wu, Q.-J.; Wang, Y.-Z. Cholesterol consumption and risk of endometrial cancer: A systematic review and dose-response meta-analysis of observational studies. Oncotarget 2016, 7, 16996-17008. [CrossRef] 
110. Lukanova, A.; Zeleniuch-Jacquotte, A.; Lundin, E.; Micheli, A.; Arslan, A.A.; Rinaldi, S.; Muti, P.; Lenner, P.; Koenig, K.L.; Biessy, C.; et al. Prediagnostic levels of C-peptide, IGF-I, IGFBP -1, -2 and -3 and risk of endometrial cancer. Int. J. Cancer 2003, 108, 262-268. [CrossRef]

111. Mulholland, H.G.; Murray, L.J.; Cardwell, C.R.; Cantwell, M.M. Dietary glycaemic index, glycaemic load and endometrial and ovarian cancer risk: A systematic review and meta-analysis. Br. J. Cancer 2008, 99, 434-441. [CrossRef]

112. Nagle, C.M.; Olsen, C.M.; Ibiebele, T.I.; Spurdle, A.B.; Webb, P.M.; the Australian Ovarian Cancer Study Group. Glycemic index, glycemic load and endometrial cancer risk: Results from the Australian National Endometrial Cancer study and an updated systematic review and meta-analysis. Eur. J. Nutr. 2012, 52, 705-715. [CrossRef]

113. Segawa, T.; Shozu, M.; Murakami, K.; Kasai, T.; Shinohara, K.; Nomura, K.; Ohno, S.; Inoue, M. Aromatase expression in stromal cells of endometrioid endometrial cancer correlates with poor survival. Clin. Cancer Res. 2005, 11, 2188-2194. [CrossRef]

114. Klopp, A.H.; Zhang, Y.; Solley, T.; Amaya-Manzanares, F.; Marini, F.; Andreeff, M.; Debeb, B.; Woodward, W.; Schmandt, R.; Broaddus, R.; et al. Omental adipose tissue-derived stromal cells promote vascularization and growth of endometrial tumors. Clin. Cancer Res. 2011, 18, 771-782. [CrossRef]

115. Guidice, L.C. Endometrium in PCOS: Implantation and predisposition to endocrine CA. Best Practice and Research. Clin. Endocrinol. Metab. 2006, 20, 235-244. [CrossRef]

116. Navaratnarajah, R.; Pillay, O.C.; Hardiman, P. Polycystic ovary syndrome and endometrial cancer. Semin. Reprod. Med. 2008, 26, 62-71. [CrossRef]

117. Horn, L.-C.; Meinel, A.; Handzel, R.; Einenkel, J. Histopathology of endometrial hyperplasia and endometrial carcinoma. Ann. Diagn. Pathol. 2007, 11, 297-311. [CrossRef]

118. Kurman, R.J.; McConnell, T.G. Precursors of endometrial and ovarian carcinoma. Virchowsv Arch. 2009, 456, 1-12. [CrossRef]

119. Sherman, M.E. Theories of endometrial carcinogenesis: A multidisciplinary approach. Mod. Pathol. 2000, 13, 295-308. [CrossRef] [PubMed]

120. Banno, K.; Kisu, I.; Yanokura, M.; Tsuji, K.; Masuda, K.; Ueki, A.; Kobayashi, Y.; Yamagami, W.; Nomura, H.; Tominaga, E.; et al. Biomarkers in endometrial cancer: Possible clinical applications (Review). Oncol. Lett. 2012, 3, 1175-1180. [CrossRef]

121. Kuhn, E.; Ayhan, A.; Bahadirli-Talbott, A.; Zhao, C.; Shih, I.-M. Molecular characterization of undifferentiated carcinoma associated with endometrioid carcinoma. Am. J. Surg. Pathol. 2014, 38, 660-665. [CrossRef]

122. Gadducci, A.; Cosio, S.; Spirito, N.; Cionini, L. Clear cell carcinoma of the endometrium: A biological and clinical enigma. Anticancer. Res. 2010, 30, 1327-2334. [PubMed]

123. Risinger, J.I.; Allard, J.; Chandran, U.; Day, R.; Chandramouli, G.V.R.; Miller, C.; Zahn, C.; Oliver, J.; Litzi, T.; Marcus, C.; et al. Gene expression analysis of early stage endometrial cancers reveals unique transcripts associated with grade and histology but not depth of invasion. Front. Oncol. 2013, 3, 139. [CrossRef]

124. Lax, S.F.; Pizer, E.S.; Ronnett, B.M.; Kurman, R.J. Clear cell carcinoma of the endometrium is characterized by a distinctive profile of p53, Ki-67, estrogen, and progesterone receptor expression. Hum. Pathol. 1998, 29, 551-558. [CrossRef]

125. Shai, A.; Segev, Y.; Narod, S.A. Genetics of endometrial cancer. Fam. Cancer 2014, 13, 499-505. [CrossRef]

126. Jia, L.; Liu, Y.; Yi, X.; Miron, A.; Crum, C.P.; Kong, B.; Zheng, W. Endometrial glandular dysplasia with frequent p53 gene mutation: A genetic evidence supporting its precancer nature for endometrial serous carcinoma. Clin. Cancer Res. 2008, 14, 2263-2269. [CrossRef]

127. Lax, S.F.; Pizer, E.S.; Ronnett, B.M.; Kurman, R.J. Comparison of estrogen and progesterone receptor, Ki-67, and p53 immunoreactivity in uterine endometrioid carcinoma and endometrioid carcinoma with squamous, mucinous, secretory, and ciliated cell differentiation. Hum. Pathol. 1998, 29, 924-931. [CrossRef]

128. Tashiro, H.; Isacson, C.; Levine, R.; Kurman, R.J.; Cho, K.R.; Hedrick, L. p53 gene mutations are common in uterine serous carcinoma and occur early in their pathogenesis. Am. J. Pathol. 1997, 150, 177-185. [PubMed]

129. Fadare, O.; Gwin, K.; Desouki, M.M.; Crispens, M.A.; Jones, H.W.; Khabele, D.; Liang, S.X.; Zheng, W.; Mohammed, K.; Hecht, J.L.; et al. The clinicopathologic significance of p53 and BAF-250a (ARID1A) expression in clear cell carcinoma of the endometrium. Mod. Pathol. 2013, 26, 1101-1110. [CrossRef] [PubMed]

130. Buza, N.; Hui, P. Marked heterogeneity ofHER2/NEUgene amplification in endometrial serous carcinoma. Genes Chromosom. Cancer 2013, 52, 1178-1186. [CrossRef] [PubMed]

131. Cianciulli, A.M.; Guadagni, F.; Marzano, R.; Benevolo, M.; Merola, R.; Giannarelli, D.; Marandino, F.; Vocaturo, G.; Mariani, L.; Mottolese, M. HER-2/neu oncogene amplification and chromosome 17 aneusomy in endometrial carcinoma: Correlation with oncoprotein expression and conventional pathological parameters. J. Exp. Clin. Cancer Res. 2003, 22, 265-271. [PubMed]

132. Manavi, M.; Bauer, M.; Baghestanian, M.; Berger, A.; Kucera, E.; Pischinger, K.; Battistutti, W.; Czerwenka, K. Oncogenic potential of c-erbB-2 and its association with c-K-ras in premalignant and malignant lesions of the human uterine endometrium. Tumor Biol. 2001, 22, 299-309. [CrossRef]

133. Jindal, A.; Thadi, A.; Shailubhai, K. Hepatocellular carcinoma: Etiology and current and future drugs. J. Clin. Exp. Hepatol. 2019, 9, 221-232. [CrossRef]

134. Lee, C.-C.; Liu, J.-Y.; Lin, J.-K.; Chu, J.-S.; Shew, J.-Y. p53 point mutation enhanced by hepatic regeneration in aflatoxin B1-induced rat liver tumors and preneoplastic lesions. Cancer Lett. 1998, 125, 1-7. [CrossRef]

135. Liu, H.; Wang, Y.; Zhou, Q.; Gui, S.-Y.; Li, X. The point mutation of p53 gene exon7 in hepatocellular carcinoma from Anhui Province, a non HCC prevalent area in China. World J. Gastroenterol. 2002, 8, 480-482. [CrossRef] 
136. Weng, M.-W.; Lee, H.-W.; Choi, B.; Wang, H.-T.; Hu, Y.; Mehta, M.; Desai, D.; Amin, S.; Zheng, Y.; Tang, M.-S. AFB1 hepatocarcinogenesis is via lipid peroxidation that inhibits DNA repair, sensitizes mutation susceptibility and induces aldehyde-DNA adducts at p53 mutational hotspot codon 249. Oncotarget 2017, 8, 18213-18226. [CrossRef]

137. Gibbons, D.L.; Byers, L.A.; Kurie, J.M. Smoking, p53 mutation, and lung cancer. Mol. Cancer Res. 2014, 12, 3-13. [CrossRef]

138. Freudenheim, J.L.; Bonner, M.; Krishnan, S.; Ambrosone, C.B.; Graham, S.; McCann, S.E.; Moysich, K.B.; Bowman, E.; Nemoto, T.; Shields, P.G. Diet and alcohol consumption in relation to p53 mutations in breast tumors. Carcinogenesis 2004, 25, 931-939. [CrossRef]

139. Hill, S.Y.; Rompala, G.; Homanics, G.E.; Zezza, N. Cross-generational effects of alcohol dependence in humans onHRASandTP53methylation in offspring. Epigenomics 2017, 9, 1189-1203. [CrossRef]

140. Zhao, M.; Howard, E.W.; Guo, Z.; Parris, A.B.; Yang, X. p53 pathway determines the cellular response to alcohol-induced DNA damage in MCF-7 breast cancer cells. PLSS ONE 2017, 12, e0175121. [CrossRef]

141. Nahum, A.; Hirsch, K.; Danilenko, M.; Watts, C.K.; Prall, O.W.; Levy, J.; Sharoni, Y. Lycopene inhibition of cell cycle progression in breast and endometrial cancer cells is associated with reduction in cyclin D levels and retention of p27Kip1 in the cyclin E-cdk2 complexes. Oncogene 2001, 20, 3428-3436. [CrossRef]

142. Nahum, A.; Zeller, L.; Danilenko, M.; Prall, O.W.J.; Watts, C.K.W.; Sutherland, R.L.; Levy, J.; Sharoni, Y. Lycopene inhibition of IGF-induced cancer cell growth depends on the level of cyclin D1. Eur. J. Nutr. 2006, 45, 275-282. [CrossRef]

143. Pelucchi, C.; Maso, L.D.; Montella, M.; Parpinel, M.; Negri, E.; Talamini, R.; Giudice, A.; Franceschi, S.; La Vecchia, C. Dietary intake of carotenoids and retinol and endometrial cancer risk in an Italian case-control study. Cancer Causes Control. 2008, 19, 1209-1215. [CrossRef]

144. Sharoni, Y.; Linnewiel-Hermoni, K.; Zango, G.; Khanin, M.; Salman, H.; Veprik, A.; Danilenko, M.; Levy, J. The role of lycopene and its derivatives in the regulation of transcription systems: Implications for cancer prevention. Am. J. Clin. Nutr. 2012, 96, 1173-1178. [CrossRef]

145. Kavanaugh, C.J.; Trumbo, P.R.; Ellwood, K.C. The U.S. Food and Drug Administration's evidence-based review for qualified health claims: Tomatoes, lycopene, and cancer. J. Natl. Cancer Inst. 2007, 99, 1074-1085. [CrossRef]

146. Slattery, M.L.; Curtin, K.; Ma, K.; Edwards, S.; Schaffer, N.; Anderson, K.; Samowitz, W. Diet activity, and lifestyle associations with p53 mutations in colon tumors. Cancer Epidemiol. Biomark. Prev. 2002, 11, 541-548. [PubMed]

147. Voskuil, D.W.; Kampman, E.; Van Kraats, A.A.; Balder, H.F.; Van Muijen, G.N.; Goldbohm, R.A.; Veer, P.V. p53 over-expression andp53 mutations in colon carcinomas: Relation to dietary risk factors. Int. J. Cancer 1999, 81, 675-681. [CrossRef]

148. Zhang, Z.-H.; Su, P.-Y.; Hao, J.-H.; Sun, Y.-H. The role of preexisting diabetes mellitus on incidence and mortality of endometrial cancer: A meta-analysis of prospective cohort studies. Int. J. Gynecol. Cancer 2013, 23, 294-303. [CrossRef] [PubMed]

149. Lai, G.Y.; Park, Y.; Hartge, P.; Hollenbeck, A.R.; Freedman, N.D. The association between self-reported diabetes and cancer incidence in the NIH-AARP Diet and Health Study. J. Clin. Endocrinol. Metab. 2013, 98, 497-502. [CrossRef] [PubMed]

150. Berstein, L.M.; Kvatchevskaya, J.O.; Poroshina, T.E.; Kovalenko, I.G.; Tsyrlina, E.V.; Zimarina, T.S.; Ourmantcheeva, A.F.; Ashrafian, L.; Thijssen, J.H.H. Insulin resistance, its consequences for the clinical course of the disease, and possibilities of correction in endometrial cancer. J. Cancer Res. Clin. Oncol. 2004, 130, 687-693. [CrossRef] [PubMed]

151. Brinton, L.A.; Sakoda, L.C.; Frederiksen, K.; Sherman, M.E.; Kjaer, S.K.; Graubard, B.I.; Olsen, J.H.; Mellemkjaer, L. Relationships of uterine and ovarian tumors to pre-existing chronic conditions. Gynecol. Oncol. 2007, 107, 487-494. [CrossRef]

152. Friberg, E.; Mantzoros, C.S.; Wolk, A. Diabetes and risk of endometrial cancer: A population-based prospective cohort study. Cancer Epidemiol. Biomark. Prev. 2007, 16, 276-280. [CrossRef]

153. Mu, N.; Zhu, Y.; Wang, Y.; Zhang, H.; Xue, F. Insulin resistance: A significant risk factor of endometrial cancer. Gynecol. Oncol. 2012, 125, 751-757. [CrossRef]

154. Soliman, P.T.; Cui, X.; Zhang, Q.; Hankinson, S.E.; Lu, K.H. Circulating adiponectin levels and risk of endometrial cancer: The prospective Nurses' Health Study. Am. J. Obstet. Gynecol. 2011, 204, 167.e1-167.e5. [CrossRef]

155. Soliman, P.T.; Wu, D.; Tortolero-Luna, G.; Schmeler, K.M.; Slomovitz, B.M.; Bray, M.S.; Gershenson, D.M.; Lu, K.H. Association between adiponectin, insulin resistance, and endometrial cancer. Cancer 2006, 106, 2376-2381. [CrossRef]

156. Cantrell, L.A.; Zhou, C.; Mendivil, A.; Malloy, K.M.; Gehrig, P.A.; Bae-Jump, V.L. Metformin is a potent inhibitor of endometrial cancer cell proliferation-implications for a novel treatment strategy. Gynecol. Oncol. 2010, 116, 92-98. [CrossRef]

157. Faivre, S.; Kroemer, G.; Raymond, E. Current development of mTOR inhibitors as anticancer agents. Nat. Rev. Drug Discov. 2006, 5, 671-688. [CrossRef]

158. Soliman, P.T.; Oh, J.C.; Schmeler, K.M.; Sun, C.C.; Slomovitz, B.M.; Gershenson, D.M.; Burke, T.W.; Lu, K.H. Risk factors for young premenopausal women with endometrial cancer. Obstet. Gynecol. 2005, 105, 575-580. [CrossRef]

159. Galuska, D.; Nolte, L.A.; Zierath, J.R.; Wallberg-Henriksson, H. Effect of metformin on insulin-stimulated glucose transport in isolated skeletal muscle obtained from patients with NIDDM. Diabetologia 1994, 37, 826-832. [CrossRef]

160. Mu, N.; Wang, Y.; Xue, F. Metformin: A potential novel endometrial cancer therapy. Int. J. Gynecol. Cancer 2012, 22, 181. [CrossRef]

161. Evans, J.M.M.; Donnelly, L.A.; Emslie-Smith, A.M.; Alessi, D.R.; Morris, A.D. Metformin and reduced risk of cancer in diabetic patients. BMJ 2005, 330, 1304-1305. [CrossRef]

162. Jiralerspong, S.; Gonzalez-Angulo, A.M.; Hung, M.-C. Expanding the arsenal: Metformin for the treatment of triple-negative breast cancer? Cell Cycle 2009, 8, 2681-2684. [CrossRef] 
163. Jiralerspong, S.; Palla, S.L.; Giordano, S.H.; Meric-Bernstam, F.; Liedtke, C.; Barnett, C.M.; Hsu, L.; Hung, M.-C.; Hortobagyi, G.N.; Gonzalez-Angulo, A.M. Metformin and pathologic complete responses to neoadjuvant chemotherapy in diabetic patients with breast cancer. J. Clin. Oncol. 2009, 27, 3297-3302. [CrossRef]

164. Zhang, H.; Gao, C.; Fang, L.; Zhao, H.-C.; Yao, S.-K. Metformin and reduced risk of hepatocellular carcinoma in diabetic patients: A meta-analysis. Scand. J. Gastroenterol. 2012, 48, 78-87. [CrossRef]

165. Zhang, P.; Li, H.; Tan, X.; Chen, L.; Wang, S. Association of metformin use with cancer incidence and mortality: A meta-analysis. Cancer Epidemiol. 2013, 37, 207-218. [CrossRef]

166. Xie, Y.; Wang, Y.-L.; Yu, L.; Hu, Q.; Ji, L.; Zhang, Y.; Liao, Q.-P. Metformin promotes progesterone receptor expression via inhibition of mammalian target of rapamycin (mTOR) in endometrial cancer cells. J. Steroid Biochem. Mol. Biol. 2011, 126, 113-120. [CrossRef]

167. Zhang, Z.; Dong, L.; Sui, L.; Yang, Y.; Liu, X.; Yu, Y.; Zhu, Y.; Feng, Y. Metformin reverses progestin resistance in endometrial cancer cells by downregulating GloI Expression. Int. J. Gynecol. Cancer 2011, 21, 213-221. [CrossRef]

168. Westin, S.N.; Fellman, B.; Sun, C.C.; Broaddus, R.R.; Woodall, M.L.; Pal, N.; Urbauer, D.L.; Ramondetta, L.M.; Schmeler, K.M.; Soliman, P.T.; et al. Prospective phase II trial of levonorgestrel intrauterine device: Nonsurgical approach for complex atypical hyperplasia and early-stage endometrial cancer. Am. J. Obstet. Gynecol. 2021, 224, 191.e1-191.e15. [CrossRef]

169. Vereide, A.B.; Kaino, T.; Sager, G.; Arnes, M.; Ørbo, A. Effect of levonorgestrel IUD and oral medroxyprogesterone acetate on glandular and stromal progesterone receptors (PRA and PRB), and estrogen receptors (ER- $\alpha$ and ER- $\beta$ ) in human endometrial hyperplasia. Gynecol. Oncol. 2006, 101, 214-223. [CrossRef]

170. Dai, D.; Wolf, D.M.; Litman, E.S.; White, M.J.; Leslie, K.K. Progesterone inhibits human endometrial cancer cell growth and invasiveness: Down-regulation of cellular adhesion molecules through progesterone B receptors. Cancer Res. 2002, 62, 881-886. [PubMed]

171. Montz, F.J.; Bristow, R.E.; Bovicelli, A.; Tomacruz, R.; Kurman, R.J. Intrauterine progesterone treatment of early endometrial cancer. Am. J. Obstet. Gynecol. 2002, 186, 651-657. [CrossRef]

172. Šmuc, T.; Rižner, T.L. Aberrant pre-receptor regulation of estrogen and progesterone action in endometrial cancer. Mol. Cell Endocrinol. 2009, 301, 74-82. [CrossRef]

173. Taylor, A.H.; Al-Azzawi, F.; Pringle, J.H.; Bell, S.C. Inhibition of endometrial carcinoma cell growth using antisense estrogen receptor oligodeoxyribonucleotides. Anticancer Res. 2003, 22, 3993-4003. [PubMed]

174. Lee, L.R.; Teng, P.-N.; Nguyen, H.; Hood, B.L.; Kavandi, L.; Wang, G.; Turbov, J.M.; Thaete, L.G.; Hamilton, C.A.; Maxwell, G.L.; et al. Progesterone enhances calcitriol antitumor activity by upregulating vitamin D receptor expression and promoting apoptosis in endometrial cancer cells. Cancer Prev. Res. 2013, 6, 731-743. [CrossRef]

175. Nguyen, H.; Ivanova, V.S.; Kavandi, L.; Rodriguez, G.C.; Maxwell, G.L.; Syed, V. Progesterone and 1,25-dihydroxyvitamin D3 inhibit endometrial cancer cell growth by upregulating semaphorin 3B and semaphorin 3F. Mol. Cancer Res. 2011, 9, 1479-1492. [CrossRef]

176. Nguyen, H.; Syed, V. Progesterone inhibits growth and induces apoptosis in cancer cells through modulation of reactive oxygen species. Gynecol. Endocrinol. 2010, 27, 830-836. [CrossRef]

177. Carswell, A.T.; Oliver, S.J.; Wentz, L.M.; Kashi, D.S.; Roberts, R.; Tang, J.C.Y.; Izard, R.M.; Jackson, S.; Allan, D.; Rhodes, L.E.; et al. Influence of vitamin D supplementation by sunlight or oral D3 on exercise performance. Med. Sci. Sports Exerc. 2018, 50, 2555-2564. [CrossRef]

178. Grant, W.B.; Fakhoury, H.M.A.; Karras, S.N.; Al Anouti, F.; Bhattoa, H.P. Variations in 25-hydroxyvitamin D in countries from the Middle East and Europe: The roles of UVB exposure and diet. Nutrients 2019, 11, 2065. [CrossRef] [PubMed]

179. Bandera, E.V.; Williams, M.G.; Sima, C.; Bayuga, S.; Pulick, K.; Wilcox, H.; Soslow, R.; Zauber, A.G.; Olson, S.H. Phytoestrogen consumption and endometrial cancer risk: A population-based case-control study in New Jersey. Cancer Causes Control 2009, 20, 1117-1127. [CrossRef] [PubMed]

180. Goodman, M.T.; Wilkens, L.R.; Hankin, J.H.; Lyu, L.-C.; Wu, A.H.; Kolonel, L.N. Association of soy and fiber consumption with the risk of endometrial cancer. Am. J. Epidemiol. 1997, 146, 294-306. [CrossRef] [PubMed]

181. Genkinger, J.M.; Friberg, E.; Goldbohm, R.A.; Wolk, A. Long-term dietary heme iron and red meat intake in relation to endometrial cancer risk. Am. J. Clin. Nutr. 2012, 96, 848-854. [CrossRef] [PubMed]

182. Kallianpur, A.R.; Lee, S.-A.; Xu, W.-H.; Zheng, W.; Gao, Y.-T.; Cai, H.; Ruan, Z.-X.; Xiang, Y.-B.; Shu, X.O. Dietary iron intake and risk of endometrial cancer: A population-based case-control study in Shanghai, China. Nutr. Cancer 2009, 62, 40-50. [CrossRef]

183. Terry, P.; Vainio, H.; Wolk, A.; Weiderpass, E. Dietary factors in relation to endometrial cancer: A nationwide case-control study in Sweden. Nutr. Cancer 2002, 42, 25-32. [CrossRef]

184. Calder, P.C. Omega-3 fatty acids and inflammatory processes. Nutrients 2010, 2, 355-374. [CrossRef]

185. Laviano, A.; Rianda, S.; Molfino, A.; Fanelli, F.R. Omega-3 fatty acids in cancer. Curr. Opin. Clin. Nutr. Metab. Care 2013, 16, 156-161. [CrossRef]

186. Arem, H.; Neuhouser, M.L.; Irwin, M.L.; Cartmel, B.; Lu, L.; Risch, H.; Mayne, S.T.; Yu, H. Omega-3 and omega-6 fatty acid intakes and endometrial cancer risk in a population-based case-control study. Eur. J. Nutr. 2012, 52, 1251-1260. [CrossRef]

187. Larsson, S.C.; Kumlin, M.; Ingelman-Sundberg, M.; Wolk, A. Dietary long-chain $\mathrm{n}-3$ fatty acids for the prevention of cancer: A review of potential mechanisms. Am. J. Clin. Nutr. 2004, 79, 935-945. [CrossRef] 
188. Serini, S.; Calviello, G. Long-chain omega-3 fatty acids and cancer. Any cause for concern. Curr. Opin. Clin. Nutr. Metab. Care 2018, 21, 83-89. [CrossRef] [PubMed]

189. Hidalgo-Mora, J.J.; García-Vigara, A.; Sánchez-Sánchez, M.L.; García-Pérez, M.; Tarín, J.; Cano, A. The Mediterranean diet: A historical perspective on food for health. Maturitas 2020, 132, 65-69. [CrossRef] [PubMed]

190. Altomare, R.; Cacciabaudo, F.; Damiano, G.; Palumbo, V.D.; Gioviale, M.C.; Bellavia, M.; Tomasello, G.; Monte, A.I.L. The Mediterranean diet: A history of health. Iran. J. Public Health 2013, 42, 449-457. [PubMed]

191. Hadziabdić, M.O.; Bozikov, V.; Pavić, E.; Romić, Z. The antioxidative protecting role of the Mediterranean diet. Coll. Antropol. 2012, 36, 1427-1434. [PubMed]

192. Trichopoulou, A.; Lagiou, P.; Kuper, H.; Trichopoulos, D. Cancer and Mediterranean dietary traditions. Cancer Epidemiol. Biomark. Prev. 2000, 9, 869-873. [PubMed]

193. Dalvi, T.B.; Canchola, A.J.; Horn-Ross, P.L. Dietary patterns, Mediterranean diet, and endometrial cancer risk. Cancer Causes Control 2007, 18, 957-966. [CrossRef]

194. Ricceri, F.; Giraudo, M.T.; Fasanelli, F.; Milanese, D.; Sciannameo, V.; Fiorini, L.; Sacerdote, C. Diet and endometrial cancer: A focus on the role of fruit and vegetable intake, Mediterranean diet and dietary inflammatory index in the endometrial cancer risk. BMC Cancer 2017, 17, 757. [CrossRef]

195. Ju, W. Red meat intake and the risk of endometrial cancer: Meta-analysis of observational studies. World J. Meta Anal. 2015, 3 , 125-132. [CrossRef]

196. Bandera, E.V.; Kushi, L.H.; Moore, D.F.; Gifkins, D.M.; McCullough, M.L. Consumption of animal foods and endometrial cancer risk: A systematic literature review and meta-analysis. Cancer Causes Control 2007, 18, 967-988. [CrossRef]

197. Zheng, W.; Kushi, L.H.; Potter, J.D.; Sellers, T.A.; Doyle, T.J.; Bostick, R.M.; Folsom, A.R. Dietary intake of energy and animal foods and endometrial cancer incidence. Am. J. Epidemiol. 1995, 142, 388-394. [CrossRef]

198. Larsson, S.C.; Wolk, A. Meat consumption and risk of colorectal cancer: A meta-analysis of prospective studies. Int. J. Cancer 2006, 119, 2657-2664. [CrossRef]

199. Bingham, S.A. High-meat diets and cancer risk. Proc. Nutr. Soc. 1999, 58, 243-248. [CrossRef]

200. Key, T.J.; Bradbury, K.E.; Perez-Cornago, A.; Sinha, R.; Tsilidis, K.K.; Tsugane, S. Diet, nutrition, and cancer risk: What do we know and what is the way forward? BMJ 2020, 368, m511. [CrossRef] [PubMed]

201. Key, T.J.; Appleby, P.N.; Spencer, E.A.; Travis, R.C.; Roddam, A.W.; Allen, N.E. Cancer incidence in vegetarians: Results from the European Prospective Investigation into Cancer and Nutrition (EPIC-Oxford). Am. J. Clin. Nutr. 2009, 89, 1620-1626. [CrossRef] [PubMed]

202. Key, T.J.; Appleby, P.N.; Spencer, E.A.; Travis, R.C.; Allen, N.E.; Thorogood, M.; Mann, J.I. Cancer incidence in British vegetarians. Br. J. Cancer 2009, 101, 192-197. [CrossRef] [PubMed]

203. Fraser, G.E. Associations between diet and cancer, ischemic heart disease, and all-cause mortality in non-Hispanic white California Seventh-day Adventists. Am. J. Clin. Nutr. 1999, 70, 532-538. [CrossRef]

204. Maximova, K.; Moez, E.K.; Dabravolskaj, J.; Ferdinands, A.R.; Dinu, I.; Siou, G.L.; Al Rajabi, A.; Veugelers, P.J. Co-consumption of vegetables and fruit, whole grains, and fiber reduces the cancer risk of red and processed meat in a large prospective cohort of adults from Alberta's Tomorrow Project. Nutrients 2020, 12, 2265. [CrossRef]

205. Zuniga, K.B.; Chan, J.M.; Ryan, C.J.; Kenfield, S.A. Diet and lifestyle considerations for patients with prostate cancer. Urol. Oncol. Semin. Orig. Investig. 2020, 38, 105-117. [CrossRef]

206. Shi, Z.; Rundle, A.; Genkinger, J.M.; Cheung, Y.K.; Ergas, I.J.; Roh, J.M.; Kushi, L.H.; Kwan, M.L.; Greenlee, H. Distinct trajectories of fruits and vegetables, dietary fat, and alcohol intake following a breast cancer diagnosis: The Pathways Study. Breast Cancer Res. Treat. 2019, 179, 229-240. [CrossRef]

207. Mossine, V.V.; Mawhinney, T.P.; Giovannucci, E.L. Dried fruit intake and cancer: A systematic review of observational studies. Adv. Nutr. 2019, 11, 237-250. [CrossRef]

208. Johansson, A.; Acosta, S. Diet and lifestyle as risk factors for carotid artery disease: A prospective cohort study. Cerebrovasc. Dis. 2020, 49, 563-569. [CrossRef]

209. Thomson, C.A.; Rock, C.L.; Giuliano, A.R.; Newton, T.R.; Cui, H.; Reid, P.M.; Green, T.L.; Alberts, D.S. Longitudinal changes in body weight and body composition among women previously treated for breast cancer consuming a high-vegetable, fruit and fiber, low-fat diet. Eur. J. Nutr. 2004, 44, 18-25. [CrossRef]

210. Buijsse, B.; Feskens, E.J.M.; Schulze, M.B.; Forouhi, N.G.; Wareham, N.J.; Sharp, S.; Palli, D.; Tognon, G.; Halkjaer, J.; Tjønneland, A.; et al. Fruit and vegetable intakes and subsequent changes in body weight in European populations: Results from the project on Diet, Obesity, and Genes (DiOGenes). Am. J. Clin. Nutr. 2009, 90, 202-209. [CrossRef]

211. Nagpal, S.; Chandraratna, R.A. Vitamin A and regulation of gene expression. Curr. Opin. Clin. Nutr. Metab. Care 1998, 1, 341-346. [CrossRef]

212. Brtko, J.; Thalhamer, J. Renaissance of the biologically active vitamin A derivatives: Established and novel directed therapies for cancer and chemoprevention. Curr. Pharm. Des. 2003, 9, 2067-2077. [CrossRef]

213. Disepio, D.; Ghosn, C.; Eckert, R.L.; Deucher, A.; Robinson, N.; Duvic, M.; Chandraratna, R.A.S.; Nagpal, S. Identification and characterization of a retinoid-induced class II tumor suppressor/growth regulatory gene. Proc. Natl. Acad. Sci. USA 1998, 95, 14811-14815. [CrossRef] 
214. Xu, W.-H.; Dai, Q.; Xiang, Y.-B.; Zhao, G.-M.; Ruan, Z.-X.; Cheng, J.-R.; Zheng, W.; Shu, X.O. Nutritional factors in relation to endometrial cancer: A report from a population-based case-control study in Shanghai, China. Int. J. Cancer 2007, 120, 1776-1781. [CrossRef]

215. Yeh, M.; Moysich, K.B.; Jayaprakash, V.; Rodabaugh, K.J.; Graham, S.; Brasure, J.R.; McCann, S.E. Higher intakes of vegetables and vegetable-related nutrients are associated with lower endometrial cancer risks. J. Nutr. 2008, 139, 317-322. [CrossRef]

216. Levi, F.; Franceschi, S.; Negri, E.; La Vecchia, C. Dietary factors and the risk of endometrial cancer. Cancer 1993, 71, 3575-3581. [CrossRef]

217. Kabat, G.C.; Park, Y.; Hollenbeck, A.R.; Schatzkin, A.; Rohan, T.E. Intake of fruits and vegetables, and risk of endometrial cancer in the NIH-AARP Diet and Health Study. Cancer Epidemiol. 2010, 34, 568-573. [CrossRef]

218. Eid, S.Y.; Althubiti, M.A.; Abdallah, M.E.; Wink, M.; El-Readi, M.Z. The carotenoid fucoxanthin can sensitize multidrug resistant cancer cells to doxorubicin via induction of apoptosis, inhibition of multidrug resistance proteins and metabolic enzymes. Phytomedicine 2020, 77, 153280. [CrossRef]

219. Veprik, A.; Khanin, M.; Linnewiel-Hermoni, K.; Danilenko, M.; Levy, J.; Sharoni, Y. Polyphenols, isothiocyanates, and carotenoid derivatives enhance estrogenic activity in bone cells but inhibit it in breast cancer cells. Am. J. Physiol. Metab. 2012, 303, 815-824. [CrossRef]

220. Bandera, E.V.; Gifkins, D.M.; Moore, D.F.; McCullough, M.L.; Kushi, L.H. Antioxidant vitamins and the risk of endometrial cancer: A dose-response meta-analysis. Cancer Causes Control 2009, 20, 699-711. [CrossRef] [PubMed]

221. Kuiper, C.; Molenaar, I.G.M.; Dachs, G.U.; Currie, M.J.; Sykes, P.H.; Vissers, M.C.M. Low ascorbate levels are associated with increased hypoxia-inducible factor- 1 activity and an aggressive tumor phenotype in endometrial cancer. Cancer Res. 2010, 70, 5749-5758. [CrossRef] [PubMed]

222. McCann, S.E.; Freudenheim, J.L.; Marshall, J.R.; Brasure, J.R.; Swanson, M.K.; Graham, S. Diet in the epidemiology of endometrial cancer in western New York (United States). Cancer Causes Control 2000, 11, 965-974. [CrossRef] [PubMed]

223. Traber, M.G.; Stevens, J.F. Vitamins C and E: Beneficial effects from a mechanistic perspective. Free. Radic. Biol. Med. 2011, 51, 1000-1013. [CrossRef] [PubMed]

224. Yu, Y.; Bae, S.; Kim, H.; Kim, Y.; Chu, N.B.; Chu, N.K.; Kang, J.S.; Lee, W.J. The anti-tumor activity of vitamin C via the increase of Fas (CD95) and MHC I expression on human stomach cancer cell line, SNU1. Immune Netw. 2011, 11, 210-215. [CrossRef]

225. Abdullah, M.; Jamil, R.T.; Attia, F.N. Vitamin C (Ascorbic Acid); StatPearls Publishing: Treasure Island, FL, USA, 2003; Available online: https://www.statpearls.com/ArticleLibrary/viewarticle/31221 (accessed on 19 April 2021).

226. Zhang, D.; Xu, P.; Li, Y.; Wei, B.; Yang, S.; Zheng, Y.; Lyu, L.; Deng, Y.; Zhai, Z.; Li, N.; et al. Association of vitamin C intake with breast cancer risk and mortality: A meta-analysis of observational studies. Aging 2020, 12, 18415-18435. [CrossRef]

227. Codini, M. Why vitamin C could be an excellent complementary remedy to conventional therapies for breast cancer. Int. J. Mol. Sci. 2020, 21, 8397. [CrossRef]

228. Magrì, A.; Germano, G.; Lorenzato, A.; Lamba, S.; Chilà, R.; Montone, M.; Amodio, V.; Ceruti, T.; Sassi, F.; Arena, S.; et al High-dose vitamin C enhances cancer immunotherapy. Sci. Transl. Med. 2020, 12, 8707. [CrossRef]

229. Lee, A.W.; Wu, A.H.; Wiensch, A.; Mukherjee, B.; Terry, K.L.; Harris, H.R.; Carney, M.E.; Jensen, A.; Cramer, D.W.; Berchuck, A.; et al. Estrogen plus progestin hormone therapy and ovarian cancer. Epidemiology 2020, 31, 402-408. [CrossRef]

230. Wang, X.; Ha, D.; Mori, H.; Chen, S. White button mushroom (Agaricus bisporus) disrupts androgen receptor signaling in human prostate cancer cells and patient-derived xenograft. J. Nutr. Biochem. 2021, 89, 108580. [CrossRef]

231. Badary, D.M.; Abou-Taleb, H. Vitamin D receptor and cellular retinol-binding protein-1 immunohistochemical expression in normal, hyperplastic and neoplastic endometrium: Possible diagnostic and therapeutic implications. Ann. Diagn. Pathol. 2020, 48, 151569. [CrossRef]

232. Duman, I.; Tiftik, R.N.; Ün, I. Effects of vitamin D analogs alfacalcidol and calcitriol on cell proliferation and migration of HEC1A endometrial adenocarcinoma cells. Nutr. Cancer 2020, 73, 273-281. [CrossRef]

233. Markowska, A.; Antoszczak, M.; Kojs, Z.; Bednarek, W.; Huczyński, A. Role of vitamin D3 in selected malignant neoplasms. Nutrition 2020, 79-80, 110964. [CrossRef]

234. Negri, E.; La Vecchia, C.; Franceschi, S.; Levi, F.; Parazzini, F. Intake of selected micronutrients and the risk of endo-metrial carcinoma. Cancer 1996, 77, 917-923. [CrossRef]

235. Wu, K.; Willett, W.C.; Chan, J.M.; Fuchs, C.S.; Colditz, G.A.; Rimm, E.B.; Giovannucci, E.L. A prospective study on supplemental vitamin E intake and risk of colon cancer in women and men. Cancer Epidemiol. Biomark. Prev. 2002, 11, 1298-1304. [PubMed]

236. Graham, S.; Zielezny, M.; Marshall, J.; Priore, R.; Freudenheim, J.; Brasure, J.; Haughey, B.; Nasca, P.; Zdeb, M. Diet in the epidemiology of postmenopausal breast cancer in the New York State cohort. Am. J. Epidemiol. 1992, 136, 1327-1337. [CrossRef]

237. Peh, H.Y.; Tan, W.D.; Liao, W.; Wong, W.F. Vitamin E therapy beyond cancer: Tocopherol versus tocotrienol. Pharmacol. Ther. 2016, 162, 152-169. [CrossRef]

238. Smolarek, A.K.; So, J.Y.; Thomas, P.E.; Lee, H.J.; Paul, S.; Dombrowski, A.; Wang, C.-X.; Saw, C.L.-L.; Khor, T.O.; Kong, A.-N.T.; et al. Dietary tocopherols inhibit cell proliferation, regulate expression of ER $\alpha$, PPAR $\gamma$, and Nrf2, and decrease serum inflammatory markers during the development of mammary hyperplasia. Mol. Carcinog. 2012, 52, 514-525. [CrossRef]

239. Jeong, N.-H.; Song, E.-S.; Lee, J.-M.; Lee, K.-B.; Kim, M.-K.; Cheon, J.-E.; Lee, J.-K.; Son, S.-K.; Lee, J.-P.; Kim, J.-H.; et al. Plasma carotenoids, retinol and tocopherol levels and the risk of ovarian cancer. Acta Obstet. Gynecol. Scand. 2009, 88, 457-462. [CrossRef] [PubMed] 
240. Bandera, C.A.; Magrina, J.F. Robotic surgery in gynecologic oncology. Curr. Opin. Obstet. Gynecol. 2009, 21, 25-30. [CrossRef] [PubMed]

241. Fernandez-Lazaro, C.I.; Martínez-González, M.A.; Aguilera-Buenosvinos, I.; Gea, A.; Ruiz-Canela, M.; Romanos-Nanclares, A.; Toledo, E. Dietary antioxidant vitamins and minerals and breast cancer risk: Prospective results from the SUN cohort. Antioxidants 2021, 10, 340. [CrossRef] [PubMed]

242. McTiernan, A. Dietary prevention of breast cancer in high-risk women: Role of carotenoids. Am. J. Clin. Nutr. 2021, 113, 499-500. [CrossRef]

243. Preci, D.P.; Almeida, A.; Weiler, A.L.; Franciosi, M.L.M.; Cardoso, A.M. Oxidative damage and antioxidants in cervical cancer. Int. J. Gynecol. Cancer 2020, 31, 265-271. [CrossRef]

244. Zare, M.; Roshan, Z.N.; Assadpour, E.; Jafari, S.M. Improving the cancer prevention/treatment role of carotenoids through various nano-delivery systems. Crit. Rev. Food Sci. Nutr. 2020, 61, 522-534. [CrossRef]

245. Kieliszek, M. Selenium-fascinating microelement, properties and sources in food. Molecules 2019, 24, 1298. [CrossRef]

246. Cunzhi, H.; Jiexian, J.; Xianwen, Z.; Jingang, G.; Shumin, Z.; Lili, D. Serum and tissue levels of six trace elements and copper/zinc ratio in patients with cervical cancer and uterine myoma. Biol. Trace Element Res. 2003, 94, 113-122. [CrossRef]

247. Ji, J.; Liu, J.; Liu, H.; Wang, Y. Effects of fermented mushroom of Cordyceps sinensis, rich in selenium, on uterine cervix cancer. Evid. Based Complement. Altern. Med. 2014, 2014, 173180. [CrossRef]

248. Micke, O.; Schomburg, L.; Buentzel, J.; Kisters, K.; Muecke, R. Selenium in oncology: From chemistry to clinics. Molecules 2009, 14, 3975-3988. [CrossRef]

249. Rudolf, E.; Rudolf, K.; Cervinka, M. Selenium activates p53 and p38 pathways and induces caspase-independent cell death in cervical cancer cells. Cell Biol. Toxicol. 2008, 24, 123-141. [CrossRef]

250. Shah, Y.M.; Al-Dhaheri, M.; Dong, Y.; Ip, C.; Jones, F.E.; Rowan, B.G. Selenium disrupts estrogen receptor $\alpha$ signaling and potentiates tamoxifen antagonism in endometrial cancer cells and tamoxifen-resistant breast cancer cells. Mol. Cancer Ther. 2005, 4, 1239-1249. [CrossRef]

251. Ganash, M. Anticancer potential of ascorbic acid and inorganic selenium on human breast cancer cell line MCF-7 and colon carcinoma HCT-116. J. Cancer Res. Ther. 2021, 17, 122-129. [CrossRef]

252. Liang, Z.-Z.; Zhu, R.-M.; Li, Y.-L.; Jiang, H.-M.; Li, R.-B.; Wang, Q.; Tang, L.-Y.; Ren, Z.-F. Differential epigenetic profiles induced by sodium selenite in breast cancer cells. J. Trace Elem. Med. Biol. 2021, 64, 126677. [CrossRef]

253. British Nutrition Foundation. Dietary calcium and health. Available online: https://www.nutrition.org.uk/bnf-publications / briefingpapers.html (accessed on 1 September 2020).

254. Bluwstein, A.; Kumar, N.; Leger, K.; Traenkle, J.; Van Oostrum, J.; Rehrauer, H.; Baudis, M.; Hottiger, M.O. PKC signaling prevents irradiation-induced apoptosis of primary human fibroblasts. Cell Death Dis. 2013, 4, e498. [CrossRef]

255. McCullough, M.L.; Bandera, E.V.; Moore, D.F.; Kushi, L.H. Vitamin D and calcium intake in relation to risk of endometrial cancer: A systematic review of the literature. Prev. Med. 2008, 46, 298-302. [CrossRef]

256. Salazar-Martinez, E.; Lazcano-Ponce, E.; Sanchez-Zamorano, L.; Gonzalez-Lira, G.; Rios, P.E.-D.L.; Hernandez-Avila, M. Dietary factors and endometrial cancer risk. Results of a case-control study in Mexico. Int. J. Gynecol. Cancer 2005, 15, 938-945. [CrossRef]

257. Youn, J.; Park, S.; Song, S.; Moon, H.; Noh, D.; Jung, S.; Lee, E.; Kim, Z.; Youn, H.J.; Cho, J.; et al. Nutrient intakes from supplement and factors associated with supplement use among breast cancer survivors: A cross-sectional study. Eur. J. Cancer Care 2021, 13447. [CrossRef]

258. Scherer, G.; Barkemeyer, H. Cadmium concentrations in tobacco and tobacco smoke. Ecotoxicol. Environ. Saf. 1983, 7, 71-78. [CrossRef]

259. American Toxic Substances and Disease Registry (ATSDR). Toxicological profile for cadmium. Available online: http://www. atsdr.cdc.gov/toxprofiles/tp5.pdf (accessed on 2 September 2020).

260. The International Agency for Research on Cancer (IARC). Tobacco smoking. In Personal Habits and Indoor Combustions; Volume 100E, ISBN 1-3-9789-2832-1373. Available online: https:/ / publications.iarc.fr/Book-And-Report-Series/Iarc-Monographs-OnThe-Identification-Of-Carcinogenic-Hazards-To-Humans/Personal-Habits-And-Indoor-Combustions-2012 (accessed on 23 January 2021).

261. Byrne, C.; Divekar, S.D.; Storchan, G.B.; Parodi, D.A.; Martin, M.B. Cadmium-a metallohormone? Toxicol. Appl. Pharmacol. 2009, 238, 266-271. [CrossRef]

262. Sun, X.; Fontaine, J.-M.; Bartl, I.; Behnam, B.; Welsh, M.J.; Benndorf, R. Induction of Hsp22 (HspB8) by estrogen and the metalloestrogen cadmium in estrogen receptor-positive breast cancer cells. Cell Stress Chaperon. 2007, 12, 307-319. [CrossRef]

263. Ali, I.; Penttinen-Damdimopoulou, P.E.; Mäkelä, S.I.; Berglund, M.; Stenius, U.; Åkesson, A.; Håkansson, H.; Halldin, K. Estrogenlike effects of cadmium in vivo do not appear to be mediated via the classical estrogen receptor transcriptional Ppthway. Environ. Health Perspect. 2010, 118, 1389-1394. [CrossRef]

264. Felix, A.S.; Yang, H.P.; Gierach, G.L.; Park, Y.; Brinton, L.A. Cigarette smoking and endometrial carcinoma risk: The role of effect modification and tumor heterogeneity. Cancer Causes Control. 2014, 25, 479-489. [CrossRef]

265. Al-Zoughool, M.; Dossus, L.; Kaaks, R.; Clavel-Chapelon, F.; Tjønneland, A.; Olsen, A.; Overvad, K.; Boutron-Ruault, M.-C.; Gauthier, E.; Linseisen, J.; et al. Risk of endometrial cancer in relationship to cigarette smoking: Results from the EPIC study. Int. J. Cancer 2007, 121, 2741-2747. [CrossRef] 
266. Viswanathan, A.N.; Feskanich, D.; De Vivo, I.; Hunter, D.J.; Barbieri, R.L.; Rosner, B.; Colditz, G.A.; Hankinson, S.E. Smoking and the risk of endometrial cancer: Results from the Nurses' Health Study. Int. J. Cancer 2005, 114, 996-1001. [CrossRef]

267. Filippini, T.; Torres, D.; Lopes, C.; Carvalho, C.; Moreira, P.; Naska, A.; Kasdagli, M.-I.; Malavolti, M.; Orsini, N.; Vinceti, M. Cadmium exposure and risk of breast cancer: A dose-response meta-analysis of cohort studies. Environ. Int. 2020, $142,105879$. [CrossRef]

268. Bloomfield, M.; Louie, M.C. Chronic cadmium exposure decreases the dependency of MCF7 breast cancer cells on ER $\alpha$. Sci. Rep. 2019, 9, 1-11. [CrossRef]

269. Rodríguez-García, C.; Sánchez-Quesada, C.; Toledo, E.; Delgado-Rodríguez, M.; Gaforio, J.J. Naturally lignan-rich foods: A dietary tool for health promotion? Molecules 2019, 24, 917. [CrossRef] [PubMed]

270. Mali, A.V.; Padhye, S.B.; Anant, S.; Hegde, M.V.; Kadam, S.S. Anticancer and antimetastatic potential of enterolactone: Clinical, preclinical and mechanistic perspectives. Eur. J. Pharmacol. 2019, 852, 107-124. [CrossRef] [PubMed]

271. Jungeström, M.B.; Thompson, L.U.; Dabrosin, C. Flaxseed and its lignans inhibit estradiol-induced growth, angiogenesis, and secretion of vascular endothelial growth factor in human breast cancer xenografts in vivo. Clin. Cancer Res. 2007, 13, 1061-1067. [CrossRef] [PubMed]

272. Cederroth, C.R.; Nef, S. Soy, phytoestrogens and metabolism: A review. Mol. Cell. Endocrinol. 2009, 304, 30-42. [CrossRef]

273. Horn-Ross, P.L.; John, E.M.; Canchola, A.J.; Stewart, S.L.; Lee, M.M. Phytoestrogen intake and endometrial cancer risk. J. Natl. Cancer Inst. 2003, 95, 1158-1164. [CrossRef]

274. Mason, J.K.; Thompson, L.U. Flaxseed and its lignan and oil components: Can they play a role in reducing the risk of and improving the treatment of breast cancer? Appl. Physiol. Nutr. Metab. 2014, 39, 663-678. [CrossRef]

275. Zaineddin, A.K.; Buck, K.; Vrieling, A.; Heinz, J.; Flesch-Janys, D.; Linseisen, J.; Chang-Claude, J. The association between dietary lignans, phytoestrogen-rich Foods, and fiber intake and postmenopausal breast cancer risk: A German case-control study. Nutr. Cancer 2012, 64, 652-665. [CrossRef]

276. Gikas, P.D.; Mokbel, K. Phytoestrogens and the risk of breast cancer: A review of the literature. Int. J. Fertil. Women's Med. 2006, 50, 250-258. [PubMed]

277. Ollberding, N.J.; Lim, U.; Wilkens, L.R.; Setiawan, V.W.; Shvetsov, Y.B.; Henderson, B.E.; Kolonel, L.N.; Goodman, M.T. Legume, soy, tofu, and isoflavone intake and endometrial cancer risk in postmenopausal women in the multiethnic cohort study. J. Natl. Cancer Inst. 2011, 104, 67-76. [CrossRef]

278. Tao, M.H.; Xu, W.H.; Zheng, W.; Gao, Y.T.; Ruan, Z.X.; Cheng, J.R.; Xiang, Y.B.; Shu, X.O. A case-control study in Shanghai of fruit and vegetable intake and endometrial cancer. Br. J. Cancer 2005, 92, 2059-2064. [CrossRef]

279. Xu, W.H.; Zheng, W.; Xiang, Y.B.; Ruan, Z.X.; Cheng, J.R.; Dai, Q.; Gao, Y.T.; Shu, X.O. Soya food intake and risk of endometrial cancer among Chinese women in Shanghai: Population based case-control study. BMJ 2004, 328, 1285. [CrossRef]

280. Wood, C.E.; Register, T.C.; Franke, A.A.; Anthony, M.S.; Cline, J.M. Dietary soy isoflavones inhibit estrogen effects in the postmenopausal breast. Cancer Res. 2006, 66, 1241-1249. [CrossRef]

281. Touillaud, M.; Gelot, A.; Mesrine, S.; Bennetau-Pelissero, C.; Clavel-Chapelon, F.; Arveux, P.; Bonnet, F.; Gunter, M.; BoutronRuault, M.-C.; Fournier, A. Use of dietary supplements containing soy isoflavones and breast cancer risk among women aged $>50$ y: A prospective study. Am. J. Clin. Nutr. 2019, 109, 597-605. [CrossRef]

282. Okekunle, A.P.; Gao, J.; Wu, X.; Feng, R.; Sun, C. Higher dietary soy intake appears inversely related to breast cancer risk independent of estrogen receptor breast cancer phenotypes. Heliyon 2020, 6, e04228. [CrossRef]

283. Lee, A.H.; Su, D.; Pasalich, M.; Tang, L.; Binns, C.W.; Qiu, L. Soy and isoflavone intake associated with reduced risk of ovarian cancer in southern Chinese women. Nutr. Res. 2014, 34, 302-307. [CrossRef]

284. Messina, M. Insights gained from 20 Years of soy research. J. Nutr. 2010, 140, 2289S-2295S. [CrossRef]

285. Maskarinec, G.; Ju, D.; Morimoto, Y.; Franke, A.A.; Stanczyk, F.Z. Soy food intake and biomarkers of breast cancer risk: Possible difference in Asian women? Nutr. Cancer 2016, 69, 146-153. [CrossRef]

286. Zhang, G.-Q.; Chen, J.-L.; Liu, Q.; Zhang, Y.; Zeng, H.; Zhao, Y. Soy intake is a with lower endometrial cancer risk: A systematic review and meta-analysis of observational studies. Medicine (Baltimore) 2015, 94, 2281. [CrossRef]

287. Zhao, T.-T.; Jin, F.; Li, J.-G.; Xu, Y.-Y.; Dong, H.-T.; Liu, Q.; Xing, P.; Zhu, G.-L.; Xu, H.; Miao, Z.-F. Dietary isoflavones or isoflavone-rich food intake and breast cancer risk: A meta-analysis of prospective cohort studies. Clin. Nutr. 2019, 38, 136-145. [CrossRef]

288. Fraser, G.E.; Jaceldo-Siegl, K.; Orlich, M.; Mashchak, A.; Sirirat, R.; Knutsen, S. Dairy, soy, and risk of breast cancer: Those confounded milks. Int. J. Epidemiol. 2020, 49, 1526-1537. [CrossRef]

289. Zhong, X.-S.; Ge, J.; Chen, S.-W.; Xiong, Y.-Q.; Ma, S.-J.; Chen, Q. Association between dietary isoflavones in soy and legumes and endometrial cancer: A systematic review and meta-analysis. J. Acad. Nutr. Diet. 2018, 118, 637-651. [CrossRef]

290. Yamamoto, S.; Sobue, T.; Kobayashi, M.; Sasaki, S.; Tsugane, S.; Japan Public Health Center-based Prospective Study on Cancer Cardiovascular Diseases Group. Soy, isoflavones, and breast cancer risk in Japan. J. Natl. Cancer Inst. 2003, 95, 906-913. [CrossRef] [PubMed]

291. Setchell, K.D.; Brown, N.M.; Desai, P.; Zimmer-Nechemias, L.; Wolfe, B.E.; Brashear, W.T.; Kirschner, A.S.; Cassidy, A.; Heubi, J.E. Bioavailability of pure isoflavones in healthy humans and analysis of commercial soy isoflavone supplements. J. Nutr. 2001, 131, 1362-1375. [CrossRef] 
292. Qiu, S.; Jiang, C. Soy and isoflavones consumption and breast cancer survival and recurrence: A systematic review and meta-analysis. Eur. J. Nutr. 2019, 58, 3079-3090. [CrossRef] [PubMed]

293. Wei, Y.; Lv, J.; Guo, Y.; Bian, Z.; Gao, M.; Du, H.; Yang, L.; Chen, Y.; Zhang, X.; Wang, T.; et al. Soy intake and breast cancer risk: A prospective study of 300,000 Chinese women and a dose-response meta-analysis. Eur. J. Epidemiol. 2019, 35, 567-578. [CrossRef] [PubMed]

294. Kazemi, A.; Barati-Boldaji, R.; Soltani, S.; Mohammadipoor, N.; Esmaeilinezhad, Z.; Clark, C.C.T.; Babajafari, S.; Akbarzadeh, M. Intake of various food groups and risk of breast cancer: A systematic review and dose-response meta-analysis of prospective studies. Adv. Nutr. 2020, 10, nmaa147. [CrossRef] [PubMed]

295. Friberg, E.; Orsini, N.; Mantzoros, C.S.; Wolk, A. Coffee drinking and risk of endometrial cancer-A population-based cohort study. Int. J. Cancer 2009, 125, 2413-2417. [CrossRef]

296. Giri, A.; Sturgeon, S.R.; Luisi, N.; Bertone-Johnson, E.; Balasubramanian, R.; Reeves, K.W. Caffeinated coffee, decaffeinated coffee and endometrial cancer risk: A prospective cohort study among US postmenopausal women. Nutrients 2011, 3, 937-950. [CrossRef]

297. Gunter, M.J.; Schaub, J.A.; Xue, X.; Freedman, N.D.; Gaudet, M.M.; Rohan, T.E.; Hollenbeck, A.R.; Sinha, R. A prospective investigation of coffee drinking and endometrial cancer incidence. Int. J. Cancer 2012, 131, E530-E536. [CrossRef]

298. Kotsopoulos, J.; Eliassen, A.E.; Missmer, S.A.; Hankinson, S.E.; Tworoger, S.S. Relationship between caffeine intake and plasma sex hormone concentrations in premenopausal and postmenopausal women. Cancer 2009, 115, 2765-2774. [CrossRef]

299. Williams, C.J.; Fargnoli, J.L.; Hwang, J.J.; van Dam, R.M.; Blackburn, G.L.; Hu, F.B.; Mantzoros, C.S. Coffee consumption is associated with higher plasma adiponectin concentrations in women with or without type 2 diabetes: A prospective cohort study. Diabetes Care 2008, 31, 504-507. [CrossRef]

300. Wu, T.; Willett, W.C.; Hankinson, S.E.; Giovannucci, E. Caffeinated coffee, decaffeinated coffee, and caffeine in relation to plasma C-peptide levels, a marker of insulin secretion, in U.S. women. Diabetes Care 2005, 28, 1390-1396. [CrossRef]

301. Sánchez-Quesada, C.; Romanos-Nanclares, A.; Navarro, A.M.; Gea, A.; Cervantes, S.; Martínez-González, M.; Toledo, E. Coffee consumption and breast cancer risk in the SUN project. Eur. J. Nutr. 2020, 59, 3461-3471. [CrossRef]

302. Je, Y.; Hankinson, S.E.; Tworoger, S.S.; De Vivo, I.; Giovannucci, E. A prospective cohort study of coffee consumption and risk of endometrial cancer over a 26-year follow-up. Cancer Epidemiol. Biomark. Prev. 2011, 20, 2487-2495. [CrossRef]

303. Nilsson, L.M.; Johansson, I.; Lenner, P.; Lindahl, B.; Van Guelpen, B. Consumption of filtered and boiled coffee and the risk of incident cancer: A prospective cohort study. Cancer Causes Control. 2010, 21, 1533-1544. [CrossRef]

304. Arthur, R.; Kirsh, V.A.; Rohan, T.E. Associations of coffee, tea and caffeine intake with risk of breast, endometrial and ovarian cancer among Canadian women. Cancer Epidemiol. 2018, 56, 75-82. [CrossRef]

305. Lee, P.M.Y.; Chan, W.C.; Kwok, C.C.-H.; Wu, C.; Law, S.-H.; Tsang, K.-H.; Yu, W.-C.; Yeung, Y.-C.; Chang, L.D.J.; Wong, C.K.M.; et al. Associations between coffee products and breast cancer risk: A case-control study in Hong Kong Chinese women. Sci. Rep. 2019, 9, 12684. [CrossRef]

306. Alicandro, G.; Tavani, A.; La Vecchia, C. Coffee and cancer risk: A summary overview. Eur. J. Cancer Prev. 2017, 26, 424-432. [CrossRef]

307. Hashibe, M.; Galeone, C.; Buys, S.S.; Gren, L.H.; Boffetta, P.; Zhang, Z.-F.; La Vecchia, C. Coffee, tea, caffeine intake, and the risk of cancer in the PLCO cohort. Br. J. Cancer 2015, 113, 809-816. [CrossRef]

308. Tang, Y.-Z.; Liu, Z.-Q. Chemical kinetic behavior of chlorogenic acid in protecting erythrocyte and DNA against radical-induced oxidation. J. Agric. Food Chem. 2008, 56, 11025-11029. [CrossRef]

309. Tunnicliffe, J.M.; Shearer, J. Coffee, glucose homeostasis, and insulin resistance: Physiological mechanisms and mediators. Appl. Physiol. Nutr. Metab. 2008, 33, 1290-1300. [CrossRef]

310. Van Dijk, A.E.; Olthof, M.R.; Meeuse, J.C.; Seebus, E.; Heine, R.J.; van Dam, R.M. Acute effects of decaffeinated coffee and the major coffee components chlorogenic acid and trigonelline on glucose tolerance. Diabetes Care 2009, 32, 1023-1025. [CrossRef]

311. Rahmani, A.H.; Al Shabrmi, F.M.; Allemailem, K.S.; Aly, S.M.; Khan, M.A. Implications of green tea and its constituents in the prevention of cancer via the modulation of cell signalling pathway. BioMed Res. Int. 2015, 2015, 925640. [CrossRef]

312. Yuan, J.-M. Cancer prevention by green tea: Evidence from epidemiologic studies. Am. J. Clin. Nutr. 2013, 98, 1676S-1681S. [CrossRef] [PubMed]

313. Kakuta, Y.; Nakaya, N.; Nagase, S.; Fujita, M.; Koizumi, T.; Okamura, C.; Niikura, H.; Ohmori, K.; Kuriyama, S.; Tase, T.; et al. Case-control study of green tea consumption and the risk of endometrial endometrioid adenocarcinoma. Cancer Causes Control. 2009, 20, 617-624. [CrossRef]

314. Manohar, M.; Fatima, I.; Saxena, R.; Chandra, V.; Sankhwar, P.L.; Dwivedi, A. (-)-Epigallocatechin-3-gallate induces apoptosis in human endometrial adenocarcinoma cells via ROS generation and p38 MAP kinase activation. J. Nutr. Biochem. 2013, 24, 940-947. [CrossRef] [PubMed]

315. Laschke, M.W.; Schwender, C.; Scheuer, C.; Vollmar, B.; Menger, M.D. Epigallocatechin-3-gallate inhibits estrogen-induced activation of endometrial cells in vitro and causes regression of endometriotic lesions in vivo. Hum. Reprod. 2008, 23, $2308-2318$. [CrossRef] [PubMed]

316. Tang, N.-P.; Li, H.; Qiu, Y.-L.; Zhou, G.-M.; Ma, J. Tea consumption and risk of endometrial cancer: A metaanalysis. Am. J. Obstet. Gynecol. 2009, 201, 605.e1-605.e8. [CrossRef] [PubMed] 
317. Man, G.C.W.; Wang, J.; Song, Y.; Wong, J.H.; Zhao, Y.; Lau, T.S.; Leung, K.T.; Chan, T.H.; Wang, H.; Kwong, J.; et al. Therapeutic potential of a novel prodrug of green tea extract in induction of apoptosis via ERK/JNK and Akt signaling pathway in human endometrial cancer. BMC Cancer 2020, 20, 964. [CrossRef] [PubMed]

318. Qin, J.; Fu, M.; Wang, J.; Huang, F.; Liu, H.; Huangfu, M.; Yu, D.; Liu, H.; Li, X.; Guan, X.; et al. PTEN/AKT/mTOR signaling mediates anticancer effects of epigallocatechin-3-gallate in ovarian cancer. Oncol. Rep. 2020, 43, 1885-1896. [CrossRef]

319. Sun, Q.; Xu, L.; Zhou, B.; Wang, Y.; Jing, Y.; Wang, B. Alcohol consumption and the risk of endometrial cancer: A meta-analysis. Asia Pac. J. Clin. Nutr. 2011, 20, 125-133. [PubMed]

320. Friberg, E.; Orsini, N.; Mantzoros, C.S.; Wolk, A. Alcohol intake and endometrial cancer risk: A meta-analysis of prospective studies. Br. J. Cancer 2010, 103, 127-131. [CrossRef]

321. Neill, A.S.; Nagle, C.M.; Protani, M.M.; Obermair, A.; Spurdle, A.B.; Webb, P.M. For the Australian National Endometrial Cancer Study Group. Aspirin, nonsteroidal anti-inflammatory drugs, paracetamol and risk of endometrial cancer: A case-control study, systematic review and meta-analysis. Int. J. Cancer 2013, 132, 1146-1155. [CrossRef]

322. Wang, L.; Li, J.; Shi, Z. Association between breastfeeding and endometrial cancer risk: Evidence from a systematic review and meta-analysis. Nutrients 2015, 7, 5697-5711. [CrossRef]

323. Kitson, S.; Ryan, N.; Mackintosh, M.L.; Edmondson, R.; Duffy, J.M.; Crosbie, E.J. Interventions for weight reduction in obesity to improve survival in women with endometrial cancer. Cochrane Database Syst. Rev. 2018, 2, CD012513. [CrossRef]

324. Cho, Y.A.; Kim, J.; Woo, H.D.; Kang, M. Dietary cadmium intake and the risk of cancer: A meta-analysis. PLoS ONE 2013, 8, e75087. [CrossRef]

325. Zhou, B.; Yang, L.; Sun, Q.; Cong, R.; Gu, H.; Tang, N.; Zhu, H.; Wang, B. Cigarette smoking and the risk of endometrial cancer: A meta-analysis. Am. J. Med. 2008, 121, 501-508.e3. [CrossRef] [PubMed]

326. Lafranconi, A.; Micek, A.; Galvano, F.; Rossetti, S.; Del Pup, L.; Berretta, M.; Facchini, G. Coffee decreases the risk of endometrial cancer: A dose-response meta-analysis of prospective cohort studies. Nutrients 2017, 9, 1223. [CrossRef]

327. Zhou, Q.; Li, H.; Zhou, J.-G.; Ma, Y.; Wu, T.; Ma, H. Green tea, black tea consumption and risk of endometrial cancer: A systematic review and meta-analysis. Arch. Gynecol. Obstet. 2016, 293, 143-155. [CrossRef]

328. Hernandez, A.V.; Pasupuleti, V.; Benites-Zapata, V.A.; Thota, P.; Deshpande, A.; Perez-Lopez, F.R. Insulin resistance and endometrial cancer risk: A systematic review and meta-analysis. Eur. J. Cancer 2015, 51, 2747-2758. [CrossRef]

329. Grosso, G.; Godos, J.; Lamuela-Raventos, R.; Ray, S.; Micek, A.; Pajak, A.; Sciacca, S.; D’Orazio, N.; Del Rio, D.; Galvano, F. A comprehensive meta-analysis on dietary flavonoid and lignan intake and cancer risk: Level of evidence and limitations. Mol. Nutr. Food Res. 2017, 61, 1600930. [CrossRef]

330. Zhao, J.; Lyu, C.; Gao, J.; Du, L.; Shan, B.; Zhang, H.; Wang, H.-Y.; Gao, Y. Dietary fat intake and endometrial cancer risk: A dose response meta-analysis. Medicine 2016, 95, e4121. [CrossRef]

331. Esposito, K.; Chiodini, P.; Capuano, A.; Bellastella, G.; Maiorino, M.I.; Giugliano, D. Metabolic syndrome and endometrial cancer: A meta-analysis. Endocrinology 2013, 45, 28-36. [CrossRef]

332. Grady, D.; Gebretsadik, T.; Kerlikowske, K.; Ernster, V.; Petitti, D. Hormone replacement therapy and endometrial cancer risk: A meta-analysis. Obstet. Gynecol. 1995, 85, 304-313. [CrossRef]

333. Zhang, Y.; Liu, H.; Yang, S.; Zhang, J.; Qian, L.; Chen, X. Overweight, obesity and endometrial cancer risk: Results from a systematic review and meta-analysis. Int. J. Biol. Markers 2014, 29, e21-e29. [CrossRef] [PubMed]

334. Schmid, D.; Behrens, G.; Keimling, M.; Jochem, C.; Ricci, C.; Leitzmann, M. A systematic review and meta-analysis of physical activity and endometrial cancer risk. Eur. J. Epidemiol. 2015, 30, 397-412. [CrossRef] [PubMed]

335. Wu, Q.-J.; Gong, T.-T.; Wang, Y.-Z. Dietary fatty acids intake and endometrial cancer risk: A dose-response meta-analysis of epidemiological studies. Oncotarget 2015, 6, 36081-36097. [CrossRef]

336. Gifkins, D.; Olson, S.H.; Demissie, K.; Lu, S.-E.; Kong, A.-N.T.; Bandera, E.V. Total and individual antioxidant intake and endometrial cancer risk: Results from a population-based case-control study in New Jersey. Cancer Causes Control 2012, 23, 887-895. [CrossRef]

337. Kho, P.F.; Glubb, D.M.; Thompson, D.J.; Spurdle, A.B.; O'Mara, T.A. Assessing the role of selenium in endometrial cancer risk: A Mendelian randomization study. Front. Oncol. 2019, 9, 182. [CrossRef]

338. Ahn, W.-S.; Kim, D.-J.; Chae, G.-T.; Lee, J.-M.; Bae, S.-M.; Sin, J.-I.; Kim, Y.-W.; Namkoong, S.-E.; Lee, I.P. Natural killer cell activity and quality of life were improved by consumption of a mushroom extract, Agaricus blazei Murill Kyowa, in gynecological cancer patients undergoing chemotherapy. Int. J. Gynecol. Cancer 2004, 14, 589-594. [CrossRef]

339. Ohno, S.; Sumiyoshi, Y.; Hashine, K.; Shirato, A.; Kyo, S.; Inoue, M. Phase I clinical study of the dietary supplement, Agaricus blazei Murill, in cancer patients in remission. Evid. Based Complement. Altern. Med. 2011, 2011, 192381. [CrossRef]

340. Roda, E.; De Luca, F.; Di Iorio, C.; Ratto, D.; Siciliani, S.; Ferrari, B.; Cobelli, F.; Borsci, G.; Priori, E.C.; Chinosi, S.; et al. Novel medicinal mushroom blend as a promising supplement in integrative oncology: A multi-tiered study using $4 \mathrm{~T} 1$ triple-negative mouse breast cancer model. Int. J. Mol. Sci. 2020, 21, 3479. [CrossRef]

341. Wong, J.H.; Ng, T.B.; Chan, H.H.L.; Liu, Q.; Man, G.C.W.; Zhang, C.Z.; Guan, S.; Ng, C.C.W.; Fang, E.F.; Wang, H.; et al. Mushroom extracts and compounds with suppressive action on breast cancer: Evidence from studies using cultured cancer cells, tumor-bearing animals, and clinical trials. Appl. Microbiol. Biotechnol. 2020, 104, 4675-4703. [CrossRef]

342. Hahne, J.C.; Meyer, S.R.; Dietl, J.; Honig, A. The effect of Cordyceps extract and a mixture of Ganoderma lucidum/Agaricus Blazi Murill extract on human endometrial cancer cell lines in vitro. Int. J. Oncol. 2014, 45, 373-382. [CrossRef] 
343. Sexton, E.; Van Themsche, C.; Leblanc, K.; Parent, S.; Lemoine, P.; Asselin, E. Resveratrol interferes with AKT activity and triggers apoptosis in human uterine cancer cells. Mol. Cancer 2006, 5, 45. [CrossRef]

344. Bhat, K.P.; Pezzuto, J.M. Resveratrol exhibits cytostatic and antiestrogenic properties with human endometrial adenocarcinoma (Ishikawa) cells. Cancer Res. 2001, 61, 6137-6144. [PubMed]

345. Dann, J.M.; Sykes, P.H.; Mason, D.R.; Evans, J.J. Regulation of vascular endothelial growth factor in endometrial tumour cells by resveratrol and EGCG. Gynecol. Oncol. 2009, 113, 374-378. [CrossRef]

346. Klinge, C.M.; Blankenship, K.A.; Risinger, K.E.; Bhatnagar, S.; Noisin, E.L.; Sumanasekera, W.K.; Zhao, L.; Brey, D.M.; Keynton, R.S. Resveratrol and estradiol rapidly activate MAPK signaling through estrogen receptors $\alpha$ and $\beta$ in endothelial cells. J. Biol. Chem. 2005, 280, 7460-7468. [CrossRef]

347. Bowers, J.L.; Tyulmenkov, V.V.; Jernigan, S.C.; Klinge, C.M. Resveratrol acts as a mixed agonist/antagonist for estrogen receptors $\alpha$ and $\beta$. Endocrinology 2000, 141, 3657-3667. [CrossRef]

348. Li, Y.; Baer, D.; Friedman, G.D.; Udaltsova, N.; Shim, V.; Klatsky, A.L. Wine, liquor, beer and risk of breast cancer in a large population. Eur. J. Cancer 2009, 45, 843-850. [CrossRef]

349. Fukuda, T.; Oda, K.; Wada-Hiraike, O.; Sone, K.; Inaba, K.; Ikeda, Y.; Makii, C.; Miyasaka, A.; Kashiyama, T.; Tanikawa, M.; et al. Autophagy inhibition augments resveratrol-induced apoptosis in Ishikawa endometrial cancer cells. Oncol. Lett. 2016, 12, 2560-2566. [CrossRef]

350. Pavan, A.R.; Da Silva, G.D.B.; Jornada, D.H.; Chiba, D.E.; Fernandes, G.F.D.S.; Chin, C.M.; Dos Santos, J.L. Unraveling the anticancer effect of curcumin and resveratrol. Nutrients 2016, 8, 628. [CrossRef] [PubMed]

351. Shehzad, A.; Khan, S.; Lee, Y.S. Curcumin molecular targets in obesity and obesity-related cancers. Futur. Oncol. 2012, 8, 179-190. [CrossRef]

352. Saydmohammed, M.; Joseph, D.; Syed, V. Curcumin suppresses constitutive activation of STAT-3 by up-regulating protein inhibitor of activated STAT-3 (PIAS-3) in ovarian and endometrial cancer cells. J. Cell. Biochem. 2010, 110, 447-456. [CrossRef] [PubMed]

353. Yu, Z.; Shah, D.M. Curcumin down-regulates Ets-1 and Bcl-2 expression in human endometrial carcinoma HEC-1-A cells. Gynecol. Oncol. 2007, 106, 541-548. [CrossRef] [PubMed]

354. Giordano, A.; Tommonaro, G. Curcumin and cancer. Nutrients 2019, 11, 2376. [CrossRef] [PubMed]

355. Wang, Y.; Yu, J.; Cui, R.; Lin, J.; Ding, X. Curcumin in treating breast cancer: A Review. J. Lab. Autom. 2016, 21, 723-731. [CrossRef]

356. Zhou, X.; Jiao, D.; Dou, M.; Zhang, W.; Lv, L.; Chen, J.; Li, L.; Wang, L.; Han, X. Curcumin inhibits the growth of triple-negative breast cancer cells by silencing EZH2 and restoring DLC1 expression. J. Cell. Mol. Med. 2020, 24, 10648-10662. [CrossRef]

357. Jahanbakhshi, F.; Dana, P.M.; Badehnoosh, B.; Yousefi, B.; Mansournia, M.A.; Jahanshahi, M.; Asemi, Z.; Halajzadeh, J. Curcumin anti-tumor effects on endometrial cancer with focus on its molecular targets. Cancer Cell Int. 2021, 21, 120. [CrossRef]

358. Aggarwal, B.B.; Ichikawa, H. Molecular targets and anticancer potential of indole-3-carbinol and its derivatives. Cell Cycle 2005, 4, 1201-1215. [CrossRef]

359. Bradlow, H.L. Review. Indole-3-carbinol as a chemoprotective agent in breast and prostate cancer. Vivo 2008, 22, 441-445. [PubMed]

360. Bradlow, H.L.; Telang, N.T.; Sepkovic, D.W.; Osborne, M.P. 2-hydroxyestrone: The 'good' estrogen. J. Endocrinol. 1996, 150, S259-S265. [PubMed]

361. Gupta, M.; McDougal, A.; Safe, S. Estrogenic and antiestrogenic activities of $16 \alpha$ - and 2-hydroxy metabolites of $17 \beta$-estradiol in MCF-7 and T47D human breast cancer cells. J. Steroid Biochem. Mol. Biol. 1998, 67, 413-419. [CrossRef]

362. Liehr, J.G. Is estradiol a genotoxic mutagenic carcinogen? Endocr. Rev. 2000, 21, 40-54. [CrossRef]

363. Michnovicz, J.J.; Adlercreutz, H.; Bradlow, H.L. Changes in levels of urinary estrogen metabolites after oral indole-3-carbinol treatment in humans. J. Natl. Cancer Inst. 1997, 89, 718-723. [CrossRef]

364. Mulvey, L.; Chandrasekaran, A.; Liu, K.; Lombardi, S.; Wang, X.-P.; Auborn, K.J.; Goodwin, L. Interplay of genes regulated by estrogen and diindolylmethane in breast cancer cell lines. Mol. Med. 2007, 13, 69-78. [CrossRef]

365. Leong, H.; Firestone, G.L.; Bjeldanes, L.F. Cytostatic effects of 3,3'-diindolylmethane in human endometrial cancer cells result from an estrogen receptor-mediated increase in transforming growth factor- $\alpha$ expression. Carcinogenesis 2001, 22, 1809-1817. [CrossRef]

366. Parajuli, B.; Shin, S.-J.; Kwon, S.-H.; Cha, S.-D.; Lee, H.-G.; Bae, I.; Cho, C.-H. The synergistic apoptotic interaction of indole-3carbinol and genistein with TRAIL on endometrial cancer cells. J. Korean Med Sci. 2013, 28, 527-533. [CrossRef]

367. Kojima, T.; Tanaka, T.; Mori, H. Chemoprevention of spontaneous endometrial cancer in female Donryu rats by dietary indole-3carbinol. Cancer Res. 1994, 54, 1446-1449. [PubMed]

368. Barrenetxe, J.; Delagrange, P.; Martínez, J.A. Physiological and metabolic functions of melatonin. J. Physiol. Biochem. 2004, 60, 61-72. [CrossRef]

369. Sanchez-Barcelo, E.J.; Cos, S.; Mediavilla, D.; Martínez-Campa, C.; González, A.; Alonso-González, C. Melatonin-estrogen interactions in breast cancer. J. Pineal Res. 2005, 38, 217-222. [CrossRef]

370. Gurunathan, S.; Qasim, M.; Kang, M.-H.; Kim, J.-H. Role and therapeutic potential of melatonin in various type of cancers. Onco. Targets Ther. 2021, 14, 2019-2052. [CrossRef]

371. Vitti-Ruela, B.V.; Dokkedal-Silva, V.; Hachul, H.; Tufik, S.; Andersen, M.L. Melatonin and vitamin D: Complementary therapeutic strategies for breast cancer. Support. Care Cancer 2021. [CrossRef] 
372. Lissoni, P.; Chilelli, M.; Villa, S.; Cerizza, L.; Tancini, G. Five years survival in metastatic non-small cell lung cancer patients treated with chemotherapy alone or chemotherapy and melatonin: A randomized trial. J. Pineal Res. 2003, 35, 12-15. [CrossRef]

373. Lissoni, P.; Malugani, F.; Brivio, F.; Piazza, A.; Vintimilla, C.; Giani, L.; Tancini, G. Total pineal endocrine substitution therapy (TPEST) as a new neuroendocrine palliative treatment of untreatable metastatic solid tumor patients: A phase II study. Neuro Endocrinol. Lett. 2003, 24, 259-262. [PubMed]

374. Reiter, R.J. Mechanisms of cancer inhibition by melatonin. J. Pineal Res. 2004, 37, 213-214. [CrossRef]

375. Sainz, R.M.; Mayo, J.C.; Tan, D.-X.; León, J.; Manchester, L.; Reiter, R.J. Melatonin reduces prostate cancer cell growth leading to neuroendocrine differentiation via a receptor and PKA independent mechanism. Prostate 2005, 63, 29-43. [CrossRef]

376. Srinivasan, V.; Spence, D.W.; Pandi-Perumal, S.R.; Trakht, I.; Cardinali, D.P. Therapeutic actions of melatonin in cancer: Possible mechanisms. Integr. Cancer Ther. 2008, 7, 189-203. [CrossRef]

377. Hardeland, R. Melatonin and inflammation-Story of a double-edged blade. J. Pineal Res. 2018, 65, e12525. [CrossRef] [PubMed]

378. Hardeland, R. Aging, melatonin, and the pro- and anti-inflammatory networks. Int. J. Mol. Sci. 2019, 20, 1223. [CrossRef] [PubMed]

379. Reiter, R.J.; Rosales-Corral, S.A.; Tan, D.-X.; Acuna-Castroviejo, D.; Qin, L.; Yang, S.-F.; Xu, K. Melatonin, a full service anti-cancer agent: Inhibition of initiation, progression and metastasis. Int. J. Mol. Sci. 2017, 18, 843. [CrossRef] [PubMed]

380. Martinez-Campa, C.; González, A.; Mediavilla, M.D.; Alonso-Gonzalez, C.; Alvarez-Garcia, V.; Sánchez-Barceló, E.J.; Cos, S. Melatonin inhibits aromatase promoter expression by regulating cyclooxygenases expression and activity in breast cancer cells. Br. J. Cancer 2009, 101, 1613-1619. [CrossRef]

381. Galano, A.; Tan, D.-X.; Reiter, R.J. Melatonin: A versatile protector against oxidative DNA damage. Molecules 2018, 23, 530. [CrossRef]

382. Reiter, R.J.; Tan, D.-X.; Mayo, J.C.; Sainz, R.M.; Leon, J.; Czarnocki, Z. Melatonin as an antioxidant: Biochemical mechanisms and pathophysiological implications in humans. Acta Biochim. Pol. 2003, 50, 1129-1146. [CrossRef] [PubMed]

383. Bondy, S.C.; Campbell, A. Mechanisms underlying tumor suppressive properties of melatonin. Int. J. Mol. Sci. 2018, 19, 2205. [CrossRef]

384. Littman, A.J.; Beresford, S.A.; White, E. The association of dietary fat and plant foods with endometrial cancer (United States). Cancer Causes Control. 2001, 12, 691-702. [CrossRef]

385. Gonzalez, C.A. The European Prospective Investigation into Cancer and Nutrition (EPIC). Public Health Nutr. 2006, 9, 124-126. [CrossRef]

386. Riboli, E.; Hunt, K.J.; Slimani, N.; Ferrari, P.; Norat, T.; Fahey, M.; Charrondière, U.R.; Hémon, B.; Casagrande, C.; Vignat, J.; et al. European Prospective Investigation into Cancer and Nutrition (EPIC): Study populations and data collection. Public Health Nutr. 2002, 5, 1113-1124. [CrossRef]

387. Cust, A.E.; Slimani, N.; Kaaks, R.; Van Bakel, M.; Biessy, C.; Ferrari, P.; Laville, M.; Tjønneland, A.; Olsen, A.; Overvad, K.; et al. Dietary carbohydrates, glycemic index, glycemic load, and endometrial cancer risk within the European Prospective Investigation into Cancer and Nutrition cohort. Am. J. Epidemiol. 2007, 166, 912-923. [CrossRef]

388. Aarestrup, J.; Kyrø, C.; Christensen, J.; Kristensen, M.; Würtz, A.M.L.; Johnsen, N.F.; Overvad, K.; Tjønneland, A.; Olsen, A. Whole grain, dietary fiber, and incidence of endometrial cancer in a Danish cohort study. Nutr. Cancer 2012, 64, 1160-1168. [CrossRef]

389. Koutoukidis, D.; Beeken, R.J.; Manchanda, R.; Burnell, M.; Ziauddeen, N.; Michalopoulou, M.; Knobf, M.T.; Lanceley, A. Diet, physical activity, and health-related outcomes of endometrial cancer survivors in a behavioral lifestyle program: The Diet and Exercise in Uterine Cancer Survivors (DEUS) parallel randomized controlled pilot trial. Int. J. Gynecol. Cancer 2019, $29,531-540$. [CrossRef]

390. Haggerty, A.F.; Hagemann, A.; Barnett, M.; Thornquist, M.; Neuhouser, M.L.; Horowitz, N.; Colditz, G.A.; Sarwer, D.B.; Ko, E.M.; Allison, K.C. A randomized, controlled, multicenter study of technology-based weight loss interventions among endometrial cancer survivors. Obesity 2017, 25, S102-S108. [CrossRef]

391. Demark-Wahnefried, W.; Cases, M.G.; Cantor, A.B.; Frugé, A.D.; Smith, K.P.; Locher, J.; Cohen, H.J.; Tsuruta, Y.; Daniel, M.; Kala, R.; et al. Pilot randomized controlled trial of a home vegetable gardening intervention among older cancer survivors shows feasibility, satisfaction, and promise in improving vegetable and fruit consumption, reassurance of worth, and the trajectory of central adiposity. J. Acad. Nutr. Diet. 2018, 118, 689-704. [CrossRef]

392. Koutoukidis, D.A.; Lopes, S.; Atkins, L.; Croker, H.; Knobf, M.T.; Lanceley, A.; Beeken, R.J. Use of intervention mapping to adapt a health behavior change intervention for endometrial cancer survivors: The shape-up following cancer treatment program. BMC Public Health 2018, 18, 415. [CrossRef] [PubMed]

393. Von Gruenigen, V.E.; Gibbons, H.E.; Kavanagh, M.B.; Janata, J.W.; Lerner, E.; Courneya, K.S. A randomized trial of a lifestyle intervention in obese endometrial cancer survivors: Quality of life outcomes and mediators of behavior change. Health Qual. Life Outcomes 2009, 7, 17. [CrossRef] [PubMed]

394. von Gruenigen, V.E.; Waggoner, S.E.; Frasure, H.E.; Kavanagh, M.B.; Janata, J.W.; Rose, P.G.; Courneya, K.S.; Lerner, E. Lifestyle challenges in endometrial cancer survivorship. Obstet. Gynecol. 2011, 117, 93-100. [CrossRef]

395. Mozaffarian, D.; Rosenberg, I.; Uauy, R. History of modern nutrition science-implications for current research, dietary guidelines, and food policy. BMJ 2018, 361, k2392. [CrossRef] 
396. Liu, B.; Young, H.; Crowe, F.L.; Benson, V.S.; Spencer, E.A.; Key, T.J.; Appleby, P.N.; Beral, V. Development and evaluation of the Oxford WebQ, a low-cost, web-based method for assessment of previous $24 \mathrm{~h}$ dietary intakes in large-scale prospective studies. Public Health Nutr. 2011, 14, 1998-2005. [CrossRef]

397. Zanini, B.; Simonetto, A.; Bertolotti, P.; Marullo, M.; Marconi, S.; Becchetti, C.; Gilioli, G.; Valerio, A.; Donato, F.; Ricci, C.; et al. A new self-administered semi-quantitative food frequency questionnaire to estimate nutrient intake among Italian adults: Development design and validation process. Nutr. Res. 2020, 80, 18-27. [CrossRef]

398. Patterson, R.E.; Kristal, A.R.; Tinker, L.F.; Carter, R.A.; Bolton, M.P.; Agurs-Collins, T. Measurement characteristics of the Women's Health Initiative food frequency questionnaire. Ann. Epidemiol. 1999, 9, 178-187. [CrossRef]

399. Hislop, T.G.; Lamb, C.W.; Ng, V.T. Differential misclassification bias and dietary recall for the distant past using a food frequency questionnaire. Nutr. Cancer 1990, 13, 223-233. [CrossRef]

400. Pierce, B.L.; Kraft, P.; Zhang, C. Mendelian randomization studies of cancer risk: A literature review. Curr. Epidemiol. Rep. 2018, 5, 184-196. [CrossRef]

401. Ioannidis, J.P.A. The challenge of reforming nutritional epidemiologic research. JAMA 2018, 320, 969-970. [CrossRef]

402. Yu, C.-H.; Wang, T.-J.; Chang, C.-L.; Liang, S.-Y.; Wu, S.-F.; Liu, C.-Y.; Lu, Y.Y. Healthy life styles, sleep and fatigue in endometrial cancer survivors: A cross-sectional study. J. Clin. Nurs. 2020, 29, 1372-1380. [CrossRef] [PubMed]

403. Playdon, M.C.; Coburn, S.B.; Moore, S.C.; Brinton, L.A.; Wentzensen, N.; Anderson, G.; Wallace, R.; Falk, R.T.; Pfeiffer, R.; Xu, X.; et al. Alcohol and oestrogen metabolites in postmenopausal women in the Women's Health Initiative Observational Study. Br. J. Cancer 2018, 118, 448-457. [CrossRef] [PubMed] 